\title{
The interpretation of the serum protein-bound iodine: A review
}

\author{
J. D. ACLAND ${ }^{1}$ \\ From the Department of Pathology, Central Middlesex Hospital, Park Royal, London
}

SYNOPSIS The effects of physiological and environmental factors, of thyroid and non-thyroid diseases, and of drugs on the serum protein-bound iodine are described and discussed.

The blood iodine consists of several fractions, not all of which are clinically important (Acland, 1958). The serum protein-bound iodine (PBI) is defined as that part of the total serum iodine which cannot be dialysed and is precipitated with the serum proteins. Physiological and pathological factors which may affect the serum PBI have been extensively reviewed (eg, Rall, Robbins, and Lewallen, 1964; Davis, 1966; Sandler and McGowan, 1967). The present review is concerned with the interpretation of the serum $\mathrm{PBI}$ in routine diagnosis.

\section{Determination of the Serum PBI}

The methods for determining serum PBI have been fully reviewed (Acland, 1958; Chaney, 1958; Henry, 1964, ch. 28; Robbins and Rall, 1967). The traditional normal range for the serum PBI in healthy adults is $4-8 \mu \mathrm{g} / 100 \mathrm{ml}$ (Henry, 1964, p. 932). Investigators who use alkaline ashing techniques for determining serum PBI have reported lower limiting values, eg, $3 \cdot 4-7 \cdot 3 \mu \mathrm{g} / 100 \mathrm{ml}(95 \%$ limits calculated from the data of Radcliff, Baker, Croydon, Hart, and Hales, 1964) and 3·5-7.5 $\mu \mathrm{g} / 100 \mathrm{ml}$ (Sisson, 1965). Workers using acid digestion techniques have reported wider normal ranges, eg, 3.6-8.8 $\mu \mathrm{g} / 100 \mathrm{ml}$ (Bodansky, Benua, and Penacchia, 1958) and 3.0$7.5 \mu \mathrm{g} / 100 \mathrm{ml}$ (Wayne, Koutras, and Alexander, 1964 -method of Farrell and Richmond, 1961). Michell (1966) reported that he had analysed 'about 500 ' sera with PBI values in the range 0.3-20.0 $\mu \mathrm{g} / 100 \mathrm{ml}$ both by the alkaline incineration method of Acland (1957) and by the Technicon PBI AutoAnalyzer (Technicon Instruments Ltd), which uses an acid digestion technique, and had found

\footnotetext{
${ }^{1}$ Present address: Department of Chemical Pathology, Royal Postgraduate Medical School, Ducane Road, London, W12.

Received for publication 20 August 1970.
}

that the regression line of one method on the other did not differ significantly from the line of agreement. Contamination by iodine drugs is a serious problem in all methods for determining proteinbound iodine.

\section{Iodothyronines in Serum}

Thyroxine $\left(\mathrm{T}_{4}\right)$ makes up the greater part of the serum protein-bound iodine. The normal range for serum $\mathrm{T}_{4}$ by column chromatography followed by alkaline ashing is quoted as 3.2-6.4 $\mu \mathrm{g}$ of $\mathrm{T}_{4}-\mathrm{I} / 100 \mathrm{ml}$ (Henry, 1964, p. 950). Interference by some, but not all, iodine drugs is eliminated by this method (Henry, 1964 , p. 950). Direct determination of $T_{4}$ in the column eluate after bromination (Pileggi and Kessler, 1968) gives results for $T_{4}-I$ which are $0.13 \mu \mathrm{g} / 100 \mathrm{ml}$ higher on average than the alkaline ashing technique. Priodax and Telepaque were found to interfere with the bromination method, but most radioopaque iodine drugs did not (Pileggi and Kessler, 1968). The normal $95 \%$ range for serum $T_{4}$ by the competitive protein-binding technique, converted to the same units, has been quoted as $2 \cdot 6-7 \cdot 2$ $\mu \mathrm{g}$ of $\mathrm{T}_{4}-\mathrm{I} / 100 \mathrm{ml}$ (Murphy and Pattee, 1966), 2.0$7 \cdot 4 \mu \mathrm{g}$ of $\mathrm{T}_{4}-\mathrm{I} / 100 \mathrm{ml}$ (Cassidy, Benotti, and Peno, 1968), 2.6-6.9 $\mu \mathrm{g}$ of $\mathrm{T}_{4}-\mathrm{I} / 100 \mathrm{ml}$ (Lucis, Cummings, Matthews, and Burry, 1969), and 2.9-7.5 $\mu \mathrm{g}$ of $\mathrm{T}_{4}$ $\mathrm{I} / 100 \mathrm{ml}$ (Ekins, Williams, and Ellis, 1969). The use of competitive protein-binding methods avoids interference by iodine drugs (Murphy, 1969) but necessitates extraction of $T_{4}$ from serum with organic solvents, which may cause artefacts unless the solvent is evaporated above $p \mathrm{H} 9$ (Bellabarba and Sterling, 1969).

The normal range $(95 \%$ limits) for total serum 3:5:3'-tri-iodothyronine $\left(\mathrm{T}_{3}\right)$, calculated from the data of Nauman, Nauman, and Werner (1967), who used a competitive pretein-binding technique, is 
0.11-0.28 $\mu \mathrm{g}$ of $\mathrm{T}_{3}-\mathrm{I} / 100 \mathrm{ml}$. The technique of Nauman et al (1967) has been criticized on the grounds that esterification artefacts could have been formed during extraction (Sterling, Bellabarba, Newman, and Brenner, 1969). A normal $95 \%$ range for total serum $T_{3}$ calculated from the data of Sterling et al (1969) is $0 \cdot 10-0 \cdot 16 \mu \mathrm{g}$ of $\mathrm{T}_{3}-\mathrm{I} / 100 \mathrm{ml}$.

$3: 3^{\prime}: 5^{\prime}:$-Tri-iodothyronine and $3: 3^{\prime}$-di-iodothyronine, although present in thyroid hydrolysates, are not normal serum constituents (Stanbury and Morris, 1957; Dunn and Stanbury, 1958).

\section{Serum Proteins which Bind Thyroid Hormones}

Nearly all the serum hormonal iodine $\left(T_{3}\right.$ and $\left.T_{4}\right)$ in serum is bound to protein (Robbins and Rall, 1960). $T_{4}$ is attached under in-vitro conditions to several proteins, the most important of which are an $\alpha_{2}$-glycoprotein, thyroxine-binding globulin (TBG), and a thyroxine-binding prealbumin (TBPA). In physiological conditions about $15 \%$ of the serum $\mathrm{T}_{4}$ is bound to TBPA (Woeber and Ingbar, 1968). The remainder is largely bound to TBG with smaller amounts attached to albumin and certain lipoproteins (Robbins and Rall, 1952; Miyai, Itoh, Abe, and Kumahara, 1968). $T_{3}$ is bound more weakly than $T_{4}$ by TBG and is not bound at all by TBPA (Ingbar, 1960).

The unbound, or 'free', $T_{3}$ or $T_{4}$ may be estimated by determining the fraction of the serum $T_{3}$ or $T_{4}$ which has passed into the diffusate after dialysing the serum until equilibrium is attained (Oppenheimer, Squef, Surks, and Hauer, 1963; Ingbar, Braverman, Dawber, and Lee, 1965). In normal sera, on the average, $99.954 \%$ of the total $T_{4}$ is protein-bound (Sterling and Brenner, 1966) and $99.54 \%$ of the total $T_{3}$ is protein-bound (Nauman et al, 1967). These authors give normal ranges of $0.036-0.056 \%$ for the free $T_{4}$ fraction and 0.18 $0.74 \%$ for the free $T_{3}$ fraction. It is important that the $\left[{ }^{131} \mathrm{I}\right] \mathrm{T}_{4}$ or ${ }^{\left[{ }^{131} \mathrm{I}\right]} \mathrm{T}_{3}$ used in the determination should not be contaminated by other iodothyronines (Volpert, Martinez, and Oppenheimer, 1967).

\section{Serum Free $T_{3}$ and Free $T_{4}$}

The normal range ( $95 \%$ limits) for the concentration of free $T_{4}$ in serum is $1 \cdot 76-3.76 \mathrm{ng}$ of $T_{4}-\mathrm{I} / 100 \mathrm{ml}$ or 35-74 pmoles/1 (calculated from the data of Sterling and Brenner, 1966) and the normal range $(95 \%$ limits) for serum free $T_{3}$ is $0.42-1.35 \mathrm{ng}$ of $T_{3}-\mathrm{I} / 100$ $\mathrm{ml}$ or 11-35 pmoles/1 (calculated from the data of Nauman et al, 1967). The upper limit of normal for the serum absolute $T_{3}$ level may be as low as 20 pmoles/l (Sterling et al, 1969).

\section{Non-hormonal Iodine in the PBI}

The PBI may contain iodoproteins, iodotyrosines, or inorganic iodide in addition to hormonal iodine. Contamination by iodine drugs is considered in a later section. The serum PBI is usually separated from free serum iodide by protein precipitation or by means of an anion-exchange resin. Thyroglobulin and iodoalbumin secreted by the thyroid gland (Robbins and Rall, 1960) and iodoalbumin secreted by the liver (Surks and Oppenheimer, 1969) remain in the protein fraction and are estimated as proteinbound iodine. Thyroglobulin is present only in minute traces in normal serum (Roitt and Torrigiani, 1967). Iodoalbumin from the liver could contribute up to 10 to $15 \%$ of the normal PBI (see Surks and Oppenheimer, 1969).

Free iodotyrosines are precipitated from serum in a zinc hydroxide precipitate but not to any significant extent in a trichloroacetic acid precipitate (O'Halloran and Wellby, 1966). If an anion exchange resin is used to remove inorganic iodide from serum, as in the case of the method used for the Technicon PBI AutoAnalyzer, iodotyrosines are included in the iodine remaining in the serum, which constitutes the 'total serum organic iodine', or TSOI (Austin and Koepke, 1966). Thus any iodotyrosines in serum are estimated as PBI if zinc hydroxide precipitation is used and as TSOI if iodide is removed from the serum by an anion exchange resin. Iodotyrosines are not found in the free state in normal sera (Wellby and O'Halloran, 1969) but are detectable in the serum in some thyroid diseases (see below). An exhaustive review of iodotyrosines in serum has been published (Rhodes, 1968). The evidence for the presence in serum of 'bound iodotyrosines', which may be identical with the serum iodoalbumin fraction of Surks and Oppenheimer (1969), has been summarized by Weinert, Masui, Radichevich, and Werner (1967).

Inorganic iodide is present in the PBI in significant quantities only if large doses of some organic iodine preparations (Chaney, 1958) or at least $1 \mathrm{~g}$ of inorganic iodide per day (Fisher, Oddie, and Epperson, 1965) have been administered.

\section{Investigation of Anomalous Serum PBI Results}

Serum PBI results which are at variance with the clinical assessment of thyroid state may be observed in any of the following situations: (1) if the serum TBG capacity is abnormal; (2) if iodinated drugs (including $T_{3}$ and $T_{4}$ ), or drugs which interfere with the analysis, have been administered; (3) if the thyroid gland is secreting a product of abnormal composition; and (4) if the peripheral metabolism 
of thyroid hormone is abnormal. Ancillary methods of investigating the serum iodine are then necessary to supplement the serum PBI determination.

\section{ABNORMALITIES IN SERUM TBG CAPACITY}

These may be detected by comparing the absolute serum free $T_{4}$ level (Sterling and Brenner, 1966; Liewendahl and Lamberg, 1969) with the serum PBI, or more simply in routine practice by comparing the uptake by various absorbing agents of [ $\left.{ }^{131} \mathrm{I}\right] \mathrm{T}_{3}$ added to serum (eg, Mitchell, Harden, and O'Rourke, 1960) with the serum protein-bound iodine. The $T_{3}$ uptake is a measure of unoccupied binding sites on TBG and is thus affected both by changes in TBG capacity and by changes in total serum $T_{4}$ (Goolden, Gartside, and Sanderson, 1967). Adsorption media in current use for $\mathrm{T}_{3}$ uptake tests include resin, Sephadex (Hansen, 1966), charcoal coated with haemoglobin (Braverman, Foster, and Mead, 1967b), and charcoal coated with bovine serum albumin (Irvine and Standeven, 1967). The 'free $\mathrm{T}_{4}$ index' or the 'free $\mathrm{T}_{4}$ factor' (Clark and Horn, 1965; Goolden et al, 1967) may also be calculated from the $T_{3}$ uptake and the proteinbound iodine. The total serum $T_{4}$ is affected in the same way as the PBI by changes in TBG capacity. $A$ free $T_{4}$ index based on the total $T_{4}$ and the resin uptake of $\left[{ }^{131} \mathrm{I}\right] \mathrm{T}_{4}$ has been proposed (Howorth and Maclagan, 1969; Maclagan and Howorth, 1969).

\section{Interference by drugs}

Assessment of thyroid function in patients who have taken drugs which affect the serum PBI is best carried out after withdrawing the drug for a sufficient length of time to allow its effect to disappear. This is not always possible if the patient has received iodine-containing drugs whose contaminating effect on the serum PBI lasts for months or years (see below). In the presence of gross contamination of the PBI with organic iodine, the $T_{3}$ uptake is unaffected (Sisson, 1965) and measurements of total serum $T_{4}$ by protein binding (Murphy, Pattee, and Gold, 1966; Cassidy et al, 1968; Ekins et al, 1969) and of free $\mathrm{T}_{4}$ by equilibrium dialysis (Sterling and Brenner, 1966) give accurate estimates of total and free serum hormonal iodine. Methods of determining free $T_{4}$ by adsorption of unbound $T_{4}$ onto Sephadex (eg, Liewendahl and Lamberg, 1969) are simpler than methods employing dialysis and are more suitable for routine use, but may be subject to artefacts during the adsorption stage which impair their accuracy (Hocman, 1966).

\section{Abnormal serum iodoamino acids}

The presence in serum of iodotyrosines or abnormal proportions of $T_{3}$ can be detected by semiquan- titative chromatography of $n$-butanol extracts of the serum. Thin-layer chromatographic methods, of which several have been published (Taurog, 1963; West, Wayne, and Chavré, 1965; Sakurada, 1965 and 1966; Row, Volpé, and Ezrin, 1966; Coenegracht and Postmes, 1967; Favino, Emrich, and von zur Mühlen, 1967; Hoppe, Zappi, and Gries, 1967; Weinert et al, 1967; Fisher, 1968), appear to be the most sensitive but have not been proven in the routine laboratory. A method of separating $T_{3}$ from $T_{4}$ by gas-liquid chromatography has been described (Jaakonmäki and Stouffer, 1967), but the preparation of suitable derivatives of $T_{3}$ and $T_{4}$ appears to be too laborious for use in a routine laboratory. Solvent extraction of serum may cause artefacts because of esterification unless the solvent is evaporated in alkaline conditions (Bellabarba and Sterling, 1969).

\section{Iodoproteins in serum}

Thyroglobulin is not extracted from serum by $n$ butanol, and can only be demonstrated chromatographically if untreated serum is used (Tong, Taurog, and Chaikoff, 1952; Robbins, 1954). The soluble iodoprotein of the thyroid gland is soluble in $n$ butanol in the presence of trichloroacetic acid (Robbins, Rall, and Rawson, 1955), but its chromatographic properties are not known.

An increase in iodoproteins may be detected in serum (McConahey, Keating, Butt, and Owen, 1961) by observing an abnormally large difference $(1 \mu \mathrm{g} / 100 \mathrm{ml})$ between the serum PBI and the serum butanol-extractable iodine (BEI) determined according to Man, Kydd, and Peters (1951). In practice, the difference between the PBI and the total $T_{4}$ measured by protein binding or by ion-exchange column (see above) would appear to be a more accurate estimate of non- $\mathrm{T}_{4}$ iodine in the serum than the PBI-BEI difference. Iodinated contaminants are not distinguished from iodoproteins by the PBItotal $T_{4}$ difference.

The rate of peripheral metabolism of thyroid hormones This is largely determined by the level of free $T_{4}$ in serum, and therefore depends not only on total $T_{4}$ but also on the binding capacity of TBG; however, other factors besides the TBG capacity may also be important (Oppenheimer, Surks, and Schwartz, 1969). Urinary losses of TBG and $T_{4}$ are important in the nephrotic syndrome (Rasmusson, 1956). Direct measurement of the rate of turnover of $T_{4}$, which is carried out by isotope studies in vivo, is not a routine procedure, and agreement has not yet been reached on the interpretation of the data from such studies (see Oppenheimer et al, 1969; Harland and Orr, 1969). 


\section{Serum PBI and the Clinical Assessment of Thyroid} Function

Usually, in practice, the diagnosis of hypothyroidism or hyperthyroidism can be made on clinical grounds alone in $80-85 \%$ of patients presenting for the first time (Wayne, 1960). The requirement is then for a laboratory test to confirm the clinical diagnosis. Experience in thyroid clinics (Trotter, 1962; Wayne et al, 1964) seems to suggest that the best single confirmatory test for hypothyroidism is the serum PBI determination and the best single confirmatory test for hyperthyroidism is the thyroid ${ }^{131}$ I uptake. Bender, Fitzgerald, and Williams (1968) recommended that the serum PBI, the thyroid ${ }^{131}$ I uptake, and the resin uptake of $\left.{ }^{131} I\right] T_{3}$ from serum should all be determined in a routine thyroid assessment. In the remaining $15-20 \%$ of cases considered by Wayne (1960), where there is diagnostic difficulty, a full thyroid investigation is necessary, but borderline or discrepant results may be obtained in all tests, including the serum PBI (Wayne et al, 1964; Thomson, Boyle, McGirr, MacDonald, Nicol, and Brown, 1968).

It is necessary to assess the thyroid state at regular intervals in treated thyrotoxic patients. Philp, Duthie, and Crooks (1968) used a combination of a clinical questionary, filled in by the patient's general practitioner, and of a serum PBI to screen patients for hypothyroidism. Barker and Bishop (1969) used for this purpose a combination of a postal symptomatic questionary, filled in by the patient, and a serum protein-bound iodine. In neither instance was the patient seen by a physician in the thyroid clinic unless the results of the questionary or the PBI determination suggested hypothyroidism. Both groups reported that there was no loss of efficiency in detecting hypothyroidism by combined questionary and serum PBI determination as compared with attendance at a thyroid clinic.

Variation of the Serum PBI with Age, Sex, and Ethnic Group

NEONATAL PERIOD AND INFANCY

The serum PBI of cord blood is above the normal adult level although below that of maternal blood (Rose, Russell, and Starr, 1963). A further increase occurs in the 12-24 hours after birth (Danowski, Johnston, Price, McKelvy, Stevenson, and McCluskey, 1951). The raised PBI in cord blood results from the high levels of TBG induced by foeto-placental oestrogen in the foetal blood (Dowling, Freinkel, and Ingbar, 1956a; Tervilä and Nordman, 1966). The postpartum increase is thought to be a physiological response to stress
(Fisher, Oddie, and Burroughs, 1962; Fisher and Oddie, 1964). From the first week onwards, the serum PBI falls steadily until at 12 weeks most values lie within the normal adult range (Danowski et al, 1951). Occasional high results have been reported up to the age of 3 years (de Pascale, 1956).

\section{Premature infants}

In premature infants the postpartum rise tends to be smaller, slower in onset, and maintained for a longer time (Perry, Hodgman, and Starr, 1965).

\section{Exchange transfusion}

Exchange transfusion lowers the serum BEI for up to four days (Westphal and Man, 1962). The serum PBI would presumably show a similar fall.

\section{CHILDHOOD AND ADOLESCENCE}

Conflicting data have been published. Danowski, Huff, Erhard, Price, Brown, Wirth, and Stevenson (1952) reported a steady decrease with age up to 12-14 years followed by an increase up to adult levels. The changes were more marked in girls than in boys. Fisher, Oddie, and Wait (1964) reported low levels in postpubertal boys as compared with prepubertal boys and adults, but no changes with age in girls. Hart and McKendry (1967) confirmed the lack of variation with age in girls, but found an increasing trend in boys between 10 and 14 years. Goldsmith, Rauh, Kloth, and Dahlgren (1967) found no significant effect of sexual maturity on serum PBI in either sex.

It may be concluded that the normal changes in serum PBI with age in childhood and adolescence are unlikely to be clinically important.

\section{OLD AGE}

Conflicting data have been reported. Some results suggest that a small fall $(0.3 \mu \mathrm{g} / 100 \mathrm{ml}$ on average) occurs over the age of 50 years (Radcliff et al, 1964); other results suggest that no change occurs (Gaffney, Gregerman, Yiengst, and Shock, 1960; Valenti and Coscelli, 1966; Lederer and Bataille, 1969). One group reported an average increase of $1.5 \mu \mathrm{g} / 100 \mathrm{ml}$ compared with young adults in a series of 14 senescent subjects (Scazziga, Lemarchand-Béraud, and Vannotti, 1964).

On balance, large serum PBI changes in old age seem unlikely to occur in the absence of thyroid disease or other conditions affecting the proteinbound iodine.

SEX DIFFERENCES IN SERUM PBI

Normal limits for the serum PBI in women were reported by Lowrey and Starr (1959) to be 0.3-0.4 $\mu \mathrm{g} / 100 \mathrm{ml}$ higher than the limits for men. This inves- 
tigation was carried out before oral contraceptives came into wide use. The presence of a sex difference has not been confirmed in subsequent less extensive investigations (Radcliff et al, 1964; Braverman, Foster and Ingbar, 1967a).

MENOPAUSE

Serum PBI levels are within normal limits in patients complaining of menopausal symptoms (Manfredi, 1964).

\section{PREGNANCY}

High oestrogen levels induce an increase in the serum TBG capacity which causes a rise in serum PBI starting at about the third week and continuing until about a week after parturition (Heinemann, Johnson, and Man, 1948; Friis and Secher, 1955; Singh and Morton, 1956; Dowling et al, 1956a). It has been reported that serum PBI levels are 2-3 $\mu \mathrm{g} / 100 \mathrm{ml}$ higher in the last trimester than in the first two trimesters (Sisson, Marshall, Byall, and Capps, 1967).

\section{Labour \\ An increase of $25 \%$ in the total $\mathrm{T}_{4}$ of maternal serum occurs in the few hours before delivery, the change being reversed in the early puerperium (Siersbaek- Nielsen and Hansen, 1969). The resin uptake of [ $\left.{ }^{131} I\right] T_{3}$ from serum follows a corresponding time course, increasing by $3 \%$ during labour and return- ing to its previous value immediately after delivery (Castron, Laakso, and Nikkari, 1969). The inter- pretation of these results is not clear.}

\section{Acute infection or weight gain in pregnancy}

Each have been reported to be associated with a fall in serum BEI which could not be explained by changes in $\mathrm{T}_{4}$-binding capacity (Man, Reid, and Jones, 1968).

\section{Threatened abortion}

Agreement has not been reached on the question whether a low serum PBI in pregnancy is a sign of threatened abortion (Magnin, Bigot, Nuon-Hoa, and Moine, 1968).

ETHNIC VARIATIONS IN THE SERUM PBI

Serum PBI levels within the limits for Caucasian adults have been reported in Japanese, Koreans, Okinawans, and Guamese (Burdick and Brown, 1968), in adult negroes (Starr and Nicoloff, 1967), and in Xavante Indians (Neel, Mikkelson, Rucknagel, Weinstein, Goyer, and Abadie, 1968). Negro preadolescent children have been reported to have serum PBI levels averaging $0.8 \mu \mathrm{g} / 100 \mathrm{ml}$ higher than Caucasian preadolescent children as a result of a higher serum TBG capacity in the negro children (Starr and Nicoloff, 1967).

In the Eskimo, upper and lower limits for the serum PBI are $1 \mu \mathrm{g} / 100 \mathrm{ml}$ above those for Caucasians (Gottschalk and Riggs, 1952; Davies and Hanson, 1965), and in Marshall Islanders the serum PBI level averages $2 \mu \mathrm{g} / 100 \mathrm{ml}$ above that of Caucasians, probably because an abnormal iodoprotein is present in the blood (Rall and Conard, 1966).

\section{Effect of Climatic and Seasonal Changes on the} Serum PBI

\section{HOT CLIMATIC CONDITIONS}

The serum PBI has been consistently reported to be low in hot weather compared with the serum PBI levels of the same subjects in temperate weather (Thompson and Kight, 1963; Watanabe, Uematsu, and Horii, 1963; Duruisseau, 1965). Although haemoconcentration is known to occur in colder weather (Wilson, 1966), the haematocrit changes in the subjects studied by Thompson and Kight (1963) and by Watanabe et al (1963) were insufficient to account for the variations in serum PBI which they observed.

\section{COLD CLIMATIC CONDITIONS}

Reports on the effect of cold weather on the serum PBI are inconsistent. Falls have been recorded by Ingbar and Bass (1957) and by Watanabe et al (1963). Gottschalk and Riggs (1952) reported that the serum PBI was unaffected by life in the Arctic. Duruisseau (1965) found that the serum PBI of subjects living in Montreal was highest in the winter

\section{Acute exposure to cold}

Cold affects the serum PBI only insofar as it causes haemoconcentration (Wilson, 1966; Berg, Utiger, Schalch, and Reichlin, 1966; Suzuki, Tonoue, Matsuzaki, and Yamamoto, 1967).

\section{Acclimatization to cold weather}

In the Antarctic this has been reported to be associated with a rise in serum PBI to normal or high levels from the low values observed during the first week of exposure (Staquet, 1965).

\section{SIZE OF THE THERMAL EFFECTS ON THE SERUM PBI}

When thermal effects occurred, the differences between the maximum and minimum serum PBI levels in different climatic conditions reported by the authors quoted were as much as $2 \mu \mathrm{g} / 100 \mathrm{ml}$. 
CLIMATIC STRESS AND THE SERUM PBI

It is possible that the degree of climatic stress may determine whether the serum PBI will fall during a particular season of the year. The climatic conditions (severe heat and severe cold) found to be associated with low serum PBI levels by Watanabe et al (1963) had previously been reported to be associated with a reduction in the count of circulating eosinophils (Watanabe, Aoki, and Nagai, 1956). This suggests that the climatic stress was sufficient to increase the output of adrenal corticosteroids in the subjects studied. Corticosteroids are known to reduce the serum PBI as a result of reduced TSH secretion and increased peripheral utilization of $T_{4}$, as well as by haemodilution (Ingbar and Freinkel, 1956; Danowski, Moses, and Mateer, 1962; Blomstedt and Einhorn, 1965 and 1967).

\section{HIGH ALTITUDE AND LOW ATMOSPHERIC PRESSURE}

The adaptation to life on a mountain or the experimental exposure of subjects to low pressure in a pressure chamber increases the serum PBI (or BEI) by 1-2 $\mu \mathrm{g} / 100 \mathrm{ml}$ (Surks, 1966; Siri, van Dyke, Winchell, Pollycove, Parker, and Cleveland, 1966; Surks, Beckwitt, and Chidsey, 1967; SchmidtKessen, 1967). The serum TBG capacity is increased but the serum free $T_{4}$ is also increased (Surks, 1966; Surks et al, 1967), so it would appear that the physiological activity of the thyroid gland is increased. The physiological mechanism underlying these changes has not been elucidated but the low oxygen tension is presumably the stimulus.

\section{Effects of Stress on the Serum PBI}

It was thought for some time that all forms of physical and emotional stress were without effect on the serum PBI (Volpé, Vale, and Johnston, 1960). This conclusion appears to be incorrect, since climatic stress severe enough to cause increased adrenocortical activity is associated with a fall in serum PBI (see previous section). It is important to exclude haemoconcentration or haemodilution in response to a stressful environmental stimulus as a cause of any changes in the serum PBI concentration which may be observed.

\section{PHYSICAL STRESS}

Muscular exercise

This is without effect on the serum PBI although it increases the rate of $T_{4}$ secretion and degradation (Irvine, 1968).

\section{Electroconvulsant therapy}

This is associated with a transient increase of $0.5 \mu \mathrm{g} /$ $100 \mathrm{ml}$ in serum PBI within the first hour followed by a fall to a level $0.5 \mu \mathrm{g} / 100 \mathrm{ml}$ below the original value, maintained between eight and 24 hours after therapy; changes in plasma volume account completely for these variations in the serum PBI (Reichlin and O'Neal, 1962).

\section{Surgical intervention}

Surgery has no effect on the serum PBI (Volpé et al, 1960).

\section{EMOTIONAL STRESS}

Tingley, Morris, Hill, and Pittman (1965) reported that emotional stress in students caused an increase of $0.5 \mu \mathrm{g} / 100 \mathrm{ml}$ in the serum protein-bound iodine. Levi (1967) subjected a group of individuals to a severe experimental psychological stress situation which was continuous for three days, and found that 30 out of 31 subjects showed increases in serum PBI ranging from 0.5 to $5.8 \mu \mathrm{g} / 100 \mathrm{ml}$. No significant changes occurred in the haematocrit. It is interesting that emotional stress should cause an increase in serum PBI whereas severe climatic stress should cause a fall, presumably associated with adrenocortical hyperactivity. Levi (1967) did not report any measurements of TBG capacity or other indices of thyroid function in his subjects. It is possibly significant that in 29 of his 31 subjects the erythrocyte sedimentation rate increased by between 1 and $12 \mathrm{~mm} / \mathrm{hr}$ after exposure to the stress situation. The mechanism by which severe emotional stress may increase the serum PBI requires further investigation.

\section{Diurnal Variations in Serum PBI}

Diurnal variations in the serum PBI level are often discounted as being clinically unimportant, eg, by Davis (1966). Nevertheless, Margolese and Golub (1957) in a careful study observed daily fluctuations of as much as $1.5 \mu \mathrm{g} / 100 \mathrm{ml}$ in the serum PBI level of individual subjects. There was evidence of autocorrelation indicating that non-random oscillatory changes in the serum PBI were occurring in a definite diurnal rhythm. Serum PBI levels were more variable in women than in men, higher values and greater scatter occurring in the luteal phase of the menstrual cycle. The mechanism of these diurnal changes is not known.

\section{Dietary and Other Environmental Effects on the Serum PBI}

\section{ABSORPTION OF IODINE OR IODIDE AFTER ENVIRONMENTAL EXPOSURE \\ Oral iodide}

Oral administration of iodide has little effect on the serum PBI until the intake reaches $1 \mathrm{~g}$ per day, when 
the serum PBI level may increase by $0.7 \mu \mathrm{g} / 100 \mathrm{ml}$ (Fisher et al, 1965). A diet containing a high proportion of seaweed causes iodide goitre (qv) to develop, with a high or normal PBI and a low serum $\mathrm{T}_{4}$ (Suzuki, Higuchi, Sawa, Ohtaki, and Horiuchi, 1965).

\section{Proprietary foods}

Some proprietary invalid or baby foods contain iodide which may cause increases in serum PBI, eg, Metrecal, which may be responsible for a rise of 1 to $3 \mu \mathrm{g} / 100 \mathrm{ml}$ (Steinberg and Leifheit, 1965).

\section{Schiller's test}

Vaginal application of iodine and potassium iodide in Schiller's test for detecting carcinoma of the cervix does not affect the serum PBI (Braverman, Perkins, Regnante, and Coté, 1968).

\section{Iodinated water}

Swimming in iodinated water has little effect on the serum PBI until the concentration in the water reaches $5 \mathrm{mg} / \mathrm{l}$ when an average increase of $1.3 \mu \mathrm{g} /$ $100 \mathrm{ml}$ in the serum PBI has been observed (Freund, Thomas, Bird, Kinman, and Black, 1966).

\section{Atmospheric exposure}

Atmospheric exposure to iodine in laundry workers resulting from the use of iodophor detergents has no effect on the serum PBI (Vought, London and Brown, 1964).

\section{DIETARY GOITROGENS}

Several edible plants, particularly in the Brassica family, contain goitrogens, either thiocyanates or thiouracil-like compounds, which may play a subsidiary part in the aetiology of endemic iodinedeficiency goitre (Kilpatrick and Wilson, 1964).

Milk substitutes containing soya bean are strongly goitrogenic in some infants (Rawson and Rall, 1955; van Wyck, Arnold, Wynn, and Pepper, 1959; Shepard, Pyne, Kirschvink, and McLean, 1960). It is possible that these infants are particularly sensitive to a goitrogen in soya bean which may interfere with $\mathrm{T}_{4}$ absorption (Pinchera, MacGillivray, Crawford, and Freeman, 1965a).

\section{EFFECT OF FLUORIDE ON THE SERUM PBI}

Fluoridation of the water supply does not affect the serum PBI (Leone, Leatherwood, Petrie, and Lieberman, 1964; Ritzel and Hertzog, 1965).

Massive doses of fluoride (5-10 mg per day for several weeks) are goitrogenic (Galletti and Joyet, 1958).

Fluoride does not interfere with the analysis of serum PBI (Hallman, Bondy, and Hagewood, 1951).

\section{Effect of Posture on the Serum PBI}

Recumbency for one and a half hours causes an average decrease of about $0.8 \mu \mathrm{g} / 100 \mathrm{ml}$ in the serum PBI as compared with the levels in the ambulant subjects, because of haemodilution (Smeenk and van den Brand, 1965). This should be borne in mind when comparing results from outpatients with those from patients in bed in hospital.

\section{Blood Collection and Preparation of the Patient}

\section{PREVENTION OF CONTAMINATION OF THE}

SAMPLE

Disinfectants containing iodine or mercurials should not be used to prepare the skin for a venepuncture.

Blood should preferably be collected into disposable plastic syringes and containers.

\section{INTRAVENOUS INFUSION}

The use of one type of plastic tubing (Bard Intracath) in intravenous infusion has been found to cause artefactually raised serum PBI values as a result of an aliphatic iodine compound being washed out of the tubing and becoming protein bound in the serum (Simbari and Houghton, 1969).

\section{EFFECT OF VENOUS OCCLUSION}

Occlusion of the veins for five minutes before venepuncture was found to increase the serum PBI by $1.35 \mu \mathrm{g} / 100 \mathrm{ml}$ on average (Lewitus and Steinitz, 1963). Samples of blood for serum PBI determinations are best taken without venous occlusion.

\section{Diagnostic Limits for the Serum PBI}

Suggested normal clinical ranges for different Caucasian population groups are given in Table I.

\begin{tabular}{|c|c|c|c|c|}
\hline \multirow[t]{4}{*}{ Age } & \multicolumn{3}{|c|}{ Premature } & \multirow[t]{2}{*}{ Full Term } \\
\hline & \multicolumn{3}{|c|}{ Weight (kg) } & \\
\hline & $1-1 \cdot 5$ & $1 \cdot 5-2$ & $2-2 \cdot 5$ & $>2.5$ \\
\hline & \multicolumn{4}{|c|}{ Normal Range for Serum PBI $(\mu \mathrm{g} / 100 \mathrm{ml})$} \\
\hline $\begin{array}{l}\text { Cord blood } \\
\text { 1st week } \\
\text { 2nd week }\end{array}$ & $\begin{array}{l}4-7 \cdot 5 \\
5-11 \cdot 5 \\
3-11\end{array}$ & $\begin{array}{l}4-8 \\
4-16 \\
5-12\end{array}$ & $\begin{array}{l}5-9 \\
6 \\
6 \cdot 5-16 \\
6 \cdot 5 \cdot 5\end{array}$ & $\begin{array}{ll}5 & -10 \\
8 & -16 \\
4 \cdot 5-10 \cdot 5\end{array}$ \\
\hline
\end{tabular}

Table Ia Ranges for serum PBI in neonates

\begin{tabular}{ll}
\hline Prepubertal Children & $\begin{array}{l}\text { Normal Range } \\
\text { for Serum PBI }(\mu \mathrm{g} / 100 \mathrm{ml})\end{array}$ \\
\hline $3 \mathrm{w}-3 \mathrm{mth}$ & $4-10 \cdot 5$ \\
$3 \mathrm{mth}-5 \mathrm{yr}$ & $4-8 \cdot 5$ \\
$5 \mathrm{yr}-$ puberty & $4-7$
\end{tabular}

Table Ib Ranges for children ${ }^{1}$ 


\begin{tabular}{ll}
\hline Postpubertal Girls and Women & $\begin{array}{l}\text { Normal Range } \\
\text { for Serum PBI }(\mu \mathrm{g} / 100 \mathrm{ml})\end{array}$ \\
\hline $\begin{array}{l}\text { Not pregnant (not on oral contraceptives) } 4-8 \\
\text { Pregnant (3rd week to end of 2nd } \\
\text { trimester) }\end{array}$ & $4 \cdot 5-11.5$ \\
$\begin{array}{l}\text { Pregnant (3rd trimester to } 1 \text { week } \\
\text { postpartum) }\end{array}$ & $7 \cdot 5-13.5$ \\
$\begin{array}{l}\text { Not pregnant on oestrogenic oral } \\
\text { contraceptives }\end{array}$ & $4 \cdot 5-13.5$ \\
\hline
\end{tabular}

Table Ic Ranges for girls and women ${ }^{1,2,3}$

\begin{tabular}{ll}
\hline Postpubertal Boys and Men & $\begin{array}{l}\text { Normal Range } \\
\text { for Serum PBI }(\mu \mathrm{g} / 100 \mathrm{ml})\end{array}$ \\
\hline Up to 18 years & $3 \cdot 5-6 \cdot 5$ \\
Over 18 years & $3 \cdot 5-7 \cdot 5$ \\
\hline
\end{tabular}

Table Id Ranges for boys and men ${ }^{1,2}$

${ }^{1}$ Diurnal variations (Margolese and Golub, 1957) are ignored. It is recommended that samples for PBI should be taken at one time of day (preferably $9.0 \mathrm{am}$ ).

'It is recommended that lower limits should be reduced by 0.5 $\mu \mathrm{g} / 100 \mathrm{ml}$ and upper limits by $1 \mu \mathrm{g} / 100 \mathrm{ml}$ to compensate for postural effects (Smeenk and van den Brand, 1965) in hospital patients in bed. 'Ekins et al (1969) reported that there was no significant difference between the range of serum total $T_{4}$ in pregnant subjects and in nonpregnant subjects on oral contraceptives. The serum PBI range in pregnancy is therefore suggested for patients on oral contraceptives.

They have been arrived at after a consideration of the work of Danowski et al (1951), de Pascale (1956), Singh and Morton (1956), Margolese and Golub (1957), Lowrey and Starr (1959), Rose et al (1963), Radcliff et al (1964), Fisher et al (1964), Perry et al (1965), Smeenk and van den Brand (1965), Sisson et al (1967), and Ekins et al (1969).

\section{Serum PBI in Thyroid Diseases}

\section{SIMPLE GOITRE}

This condition results from iodine deficiency or from the presence of goitrogens in the diet. The pathological changes in the thyroid gland are caused by increased secretion of TSH in response to a reduced output of thyroid hormone. The natural history of simple goitre is progressive (Taylor, 1953). In its later stages the disease is often called 'nodular' goitre. The term 'sporadic' goitre is used to describe cases of simple goitre which appear in a population whose iodine intake is normal, whereas the term 'endemic' goitre refers to simple goitre which occurs in a large proportion of a population whose iodine intake is low. Patients suffering from iodinedeficiency goitre are characteristically euthyroid, and the hypothyroidism or hyperthyroidism which occur rarely in such patients are independent of the endemic goitre (Wayne et al, 1964; Matovinović and Ramalingaswami, 1960; Clements, 1960).

In endemic goitre, most serum PBI levels are at the lower end of the normal range, but there is a wide scatter of values including some very low and some very high results (Ramalingaswami, 1964; Buttfield, Black, Hoffman, Mason, Wellby, Good, and Hetzel, 1966). Low serum PBI levels are often not associated with clinical hypothyroidism (Ramalingaswami, 1964), suggesting that physiological adaptation may occur to the low iodine intake. The secretion of a higher proportion of $T_{3}$ by the thyroid gland, demonstrated by de Visscher, Beckers, van den Schriek, de Smet, Ermans, Galperin, and Bastenie(1961)and Parra Jiménez, García, Roche, and Gaede (1962), would conserve iodine and might explain the discrepant values. It is also possible that malnutrition and consequent hypoproteinaemia, which may be present in many endemic goitrous areas, could reduce the serum TBG capacity.

High serum PBI levels may be associated with the presence of a solitary hyperfunctioning nodule, the so-called 'toxic adenoma', which has an indeterminate natural history (Silverstein, Burke, and Cogan, 1967; Horst, Rösler, Schneider, and Labhart, 1967). In one patient, after haemorrhage into a colloid nodule, the serum PBI was found to be raised either as a result of the release of thyroid iodine or because thyrotoxicosis was already present and precipitated the haemorrhage (Greenberg, 1966).

About $10 \%$ of patients with simple goitre have been reported to have an increased PBI-BEI difference, suggesting the presence of iodotyrosines or abnormal serum iodoproteins in simple goitre (McConahey et al, 1961).

FAMILIAL GOITRE WITH DYSHORMONOGENESIS From time to time cases of goitre showing a marked familial incidence have been described. Further study showed that these patients' condition could be ascribed to deficiencies in enzymes required for the synthesis of thyroid hormone (see accounts by Wolff, Thompson, and Robbins, 1964; Murray and McGirr, 1964; Lissitzky, Codaccioni, Cartouzou, and Mante, 1964; Klevit, Eberlein, and Bongiovanni, 1965; Bax, 1966; Lizarralde, Jones, Seal, and Jones, 1966; Lissitzky, Codaccioni, Bismuth, and Depieds, 1967).

The protein molecule of thyroglobulin is synthesized first and is subsequently iodinated in several stages (see Pastan, 1966; Pitt-Rivers, 1967). Iodide is first concentrated in the gland by an active transport mechanism, the 'iodide trap'. Iodide is then oxidized by the thyroid peroxidase and combines with the enzyme to form 'active iodine', which iodinates tyrosine residues in thyroglobulin to MIT and DIT residues (see Nunez and Pommier, 1968). Two iodotyrosine residues are finally coupled together to form an iodothyronine residue in thyro- 
globulin. Thyroglobulin is stored in the thyroid follicles and hormonal iodine $\left(T_{3}\right.$ and $\left.T_{4}\right)$ is released by subsequent hydrolysis of thyroglobulin. DIT and MIT, which are also released by hydrolysis of thyroglobulin, are rapidly deiodinated by the thyroid dehalogenase, and their iodine is returned to the intrathyroidal iodide pool.

The enzyme defect which causes familial goitre may occur at any of the stages of hormone synthesis. Clinically, the patients are always goitrous and may show additional familial disorders, eg, deaf mutism in Pendred's syndrome, and they may be either euthyroid or hypothyroid (see references quoted above).

\section{TARGET ORGAN REFRACTORINESS}

A familial syndrome, including goitre, deaf mutism, and stippled epiphyses, has been reported in which a high serum PBI and $T_{4}$ were attributed to targetorgan refractoriness (Refetoff, de Wind, and de Groot, 1967).

\section{IODIDE GOITRE}

Long-continued administration of iodide, iodinecontaining foods, or drugs which are metabolized to iodide may cause myxoedema and goitre in susceptible individuals, with a normal or high serum PBI and low serum $T_{4}$ levels (see review by Wolff, 1969). Wolff (1969) considered that the high serum PBI level resulted from iodide contamination, but Danowski, Johnston, and Greenman (1950) found that the serum PBI level remained raised after ceasing iodide administration when the plasma inorganic iodide had returned to normal. These findings suggested that iodide caused an increase in serum PBI due to the formation of iodoproteins.

\section{HYPOTHYROIDISM}

Clinical aspects of hypothyroidism are discussed in standard texts (eg, Trotter, 1962; Means, de Groot, and Stanbury, 1963; Wayne et al, 1964). The serum PBI tends to be low in all types of hypothyroidism, whether primary or secondary to hypopituitarism, except in some forms of thyroid dyshormonogenesis (Werner, Block, Mandl, and Kassenaar, 1957) and in iodide goitre (see above), when the serum PBI may be normal or high because iodotyrosines or iodoproteins in the serum are estimated as proteinbound iodine. There is not much overlap between the serum PBI ranges for hypothyroid and euthyroid subjects. Radcliff et al (1964) found that about $2 \%$ of 37 hypothyroid patients had a serum PBI above $3.4 \mu \mathrm{g} / 100 \mathrm{ml}$ and about $2 \%$ of 311 euthyroid subjects had a serum PBI below $3.4 \mu \mathrm{g} / 100 \mathrm{ml}$ (lowest $2.7 \mu \mathrm{g} / 100 \mathrm{ml})$. Bender et al (1968) found no hypothyroid patients out of 50 with a serum PBI above
$3.7 \mu \mathrm{g} / 100 \mathrm{ml}$, and about $7 \%$ of 724 euthyroid patients with a serum PBI below $3.8 \mu \mathrm{g} / 100 \mathrm{ml}$ (lowest $2 \cdot 3 \mu \mathrm{g} / 100 \mathrm{ml}$ ).

\section{HY PERTHYROIDISM}

Clinical hyperthyroidism (see Trotter, 1962; Means et al, 1963; Wayne et al, 1964) is a feature of Graves' disease (diffuse toxic goitre) and toxic nodular goitre, and may occur in association with a solitary thyroid adenoma, with De Quervain's thyroiditis, with Hashimoto's thyroiditis, and in thyroid addiction, and also be associated with a dermoid cyst and struma ovarii (Perlmutter and Mufson, 1951).

Different authors have reported a different degree of overlap between the serum PBI ranges in hyperthyroid and euthyroid subjects. Wayne et al (1964, p. 176) found serum PBI levels ranging from 4 to $21.6 \mu \mathrm{g} / 100 \mathrm{ml}$ in 40 clinically hyperthyroid patients, compared with their normal range of 3 to $7.5 \mu \mathrm{g}$, $100 \mathrm{ml}$; Radcliff et al (1964) found PBI levels between 5.5 and $16.25 \mu \mathrm{g} / 100 \mathrm{ml}$ in 41 clinically hyperthyroid patients, compared with their normal range of 3.4 to $7 \cdot 3 \mu \mathrm{g} / 100 \mathrm{ml}$. On the other hand, Bender et al (1968) found only four out of 115 hyperthyroid patients with serum PBI levels below $8.4 \mu \mathrm{g} / 100 \mathrm{ml}$ but 83 out of 724 euthyroid patients with serum PBI levels between 8.0 and $12.8 \mu \mathrm{g} / 100$ $\mathrm{ml}$. Clinical experience seems to indicate that the serum PBI does not usually discriminate between hyperthyroid and euthyroid subjects as well as the thyroid ${ }^{131}$ I uptake, although the latter test is less reliable than the serum PBI when the intrathyroidal or extrathyroidal iodine pools are abnormal in size (Wayne et al, 1964, p. 224).

\section{GRAVES' DISEASE (THYROTOXICOSIS)}

Characteristically, patients suffering from Graves' disease show a diffuse goitre and hyperthyroidism, with or without infiltrative orbitopathy, and they often have high levels of the long-acting thyroid stimulator (LATS) in the serum (Major and Munro, 1962; Wayne et al, 1964; Pinchera, Pinchera, and Stanbury, 1965b). The severity of the exophthalmos does not appear to be related to the serum level of LATS (Major and Munro, 1962; Pinchera, Pinchera, and Stanbury, 1965b). A few patients with progressive exophthalmos and high serum levels of LATS, who are thus presumed to have active Graves' disease, may be euthyroid or hypothyroid as a result of a low thyroid reserve (Liddle, Heyssel, and McKenzie, 1965). Thyroid acropachy may occur in untreated thyrotoxic patients or in thyrotoxic patients rendered euthyroid or hypothyroid by treatment (Gimlette, 1960; Kinsella and Back, 1968). It is associated with high serum levels of LATS (Pinchera et al, 1965b). 
INFECTIVE THYROIDITIS

The diagnosis of this rare condition is made on clinical grounds without recourse to the serum PBI (Hendrick, 1956). Temporary hypothyroidism may follow medical or surgical treatment (Hendrick, 1956). A normal serum PBI has been reported in one case at the time of surgery (Richie, 1959).

SUBACUTE GRANULOMATOUS (DE QUERVAIN'S) THYROIDITIS

De Quervain's thyroiditis is a chronic inflammatory condition of unknown, possibly viral, aetiology (see Czerniak and Harell-Steinberg, 1957; Trotter, 1962; Hintze, Fortelius, and Railo, 1964; Skillern, 1964; Wayne et al, 1964). In the early stages, a raised serum PBI level is associated with a depressed thyroid 131I uptake. The high serum PBI level is sometimes caused by the presence of an abnormal serum iodoprotein (Ingbar and Freinkel, 1958), but a high serum $T_{4}$ level and frank thyrotoxicosis may be present. In later phases, low or low normal serum PBI levels may be observed.

HASHIMOTO'S THYROIDITIS AND FOCAL LYMPHOCYTIC THYROIDITIS

Both these diseases are associated with the presence of antithyroid antibodies in the serum and thus appear to have an autoimmune aetiology (see Means et al, 1963; Paine, Terplan, Rose, Witebsky, and Egan, 1957). Lymphocytic thyroiditis is distinguished from Hashimoto's disease by the type of lymphocytic infiltration, which appears in discrete foci in the former but is diffuse in the latter, and by the absence in lymphocytic thyroiditis of the Askanazy cells which are typical of Hashimoto's disease (Williams and Doniach, 1962).

In Hashimoto's disease, the patients may present in hyperthyroid, euthyroid, or hypothyroid states (Means et al, 1963). In the active phase, thyroglobulin in the serum may cause elevations of the serum PBI (Owen and McConahey, 1956; McConahey et al, 1961). In the fibrous variant of Hashimoto's disease the lymphocytic and fibrous infiltration of the thyroid gland is marked, and low serum PBI levels are found from the beginning (Beierwaltes, 1965). Hashimoto's thyroiditis has a well known association with collagen diseases (Means et al, 1963).

In focal lymphocytic thyroiditis the serum PBI is variable (Gribetz, Talbot, and Crawford, 1954).

RIEDEL'S STRUMA

This rare disease is an invasive fibrous thyroiditis characterized by dense fibrous adhesions extending into the tissues of the neck around the thyroid. Woolner, McConahey, and Beahrs (1957) observed five hypothyroid patients in a series of 20 suffering from Riedel's struma, the rest being euthyroid.

NEOPLASMS OF THE THYROID GLAND

Patients with thyroid neoplasms are usually euthyroid. Lindsay $(1960$, p. 27$)$ reported a $2 \%$ incidence of hyperthyroidism and a $4 \%$ incidence of hypothyroidism in a series of 293 patients with thyroid cancer. Raised serum PBI levels associated with thyroid tumours usually result from the presence of iodoproteins in serum (Robbins et al, 1955). Mack, Hart, Druet, and Bauer (1961) described a patient with a thyroid tumour which was shown by chromatographic examination of the serum to secrete mainly $T_{3}$. They reported that after radiotherapy the proportion of $T_{4}$ to $T_{3}$ reverted to normal.

ABNORMALITIES OF THE SERUM IODINE IN THYROID DISEASES

Iodotyrosines may form the major serum iodine component in certain types of thyroid dyshormonogenesis (Werner et al, 1957). Significant amounts of iodotyrosines (up to $10 \%$ of the total serum iodine) have been reported to be present in the sera of 78 out of 128 thyrotoxic patients (Farran, Lea, Goolden, and Abbott, 1959; Shalom, 1966; Földes, Gyertyánfy, Tamás, Gesztesi, and Takács, 1967; Wellby and O'Halloran, 1969).

A high ratio of $T_{3}$ to $T_{4}$ in the serum has been reported in five out of nine patients with endemic goitre (de Visscher et al, 1961) and the observation was confirmed by Parra Jiménez et al (1962). High serum $T_{3}$ levels have been reported in individual patients suffering from some types of thyroid dyshormonogenesis (Rupp, Chavarria, Paschkis, and Chublarian, 1959; Werner, Row, and Radichevich, 1960; Lissitzky et al, 1967), from a toxic thyroid adenoma (Shimaoka, 1963), from thyrotoxicosis (Rupp and Paschkis, 1961), and from thyroid carcinoma (Mack et al, 1961).

Abnormal amounts of iodoproteins, either thyroglobulin or an iodoalbumin, have been found in the serum in association with simple goitre (Brown, Lowenstein, Greenspan, and Mangum, 1966), with some autonomous thyroid nodules (Kahn, Cogan, and Berger, 1962), in some types of thyroid dyshormonogenesis (de Groot and Stanbury, 1959; Dowling, Ingbar, and Freinkel, 1961; Lissitzky et al, 1964), after iodide administration (Danowski et al, 1950), in thyrotoxicosis after therapeutic doses of radioiodine (Cameron and Fletcher, 1959; Owen, McConahey, Childs, and McKenzie, 1960; Cavalieri, 1961 ; Stanbury and Janssen, 1962), in De Quervain's thyroiditis (Inghar and Freinkel, 1958), in Hashi- 
moto's thyroiditis (Owen and McConahey, 1956), and in thyroid carcinoma (Robbins et al, 1955).

\section{Effect of Non-thyroid Diseases on the Serum PBI}

Euthyroid patients suffering from non-thyroid diseases may have serum PBI levels outside the normal range as a result of (1) changes in the serum TBG capacity, eg, in acute intermittent porphyria (Hollander, Scott, Tschudy, Perlroth, Waxman, and Sterling, 1967b), or (2) a combination of a reduced serum TBG capacity and urinary losses of $T_{4}$ and TBG, eg, in the nephrotic syndrome (Rasmusson, 1956). Increased faecal losses of $T_{4}$ in active pancreatic steatorrhoea do not reduce the serum PBI level (Hiss and Dowling, 1962) and are probably unimportant clinically except in the case of goitrogenic soya bean preparations, which are thought to contain a factor which interferes specifically with $T_{4}$ absorption in susceptible subjects (Pinchera et al, 1965a).

In addition, abnormal serum PBI levels in nonthyroid disease may be observed because the rate of secretion of TSH by the pituitary has been affected, because the non-thyroid disease has an association with thyroid disease, or because the non-thyroid disease is a manifestation of a disorder of the thyroid gland.

In many cases of non-thyroid diseases discrepancies may arise between the clinical thyroid state and the serum free $T_{4}$ level because of abnormalities in the tissue binding and metabolism of $T_{4}$ (Oppenheimer, 1968; Oppenheimer et al, 1969). The influence of these changes in peripheral $T_{4}$ metabolism in non-thyroid disease on the serum PBI level has not yet been fully assessed.

\section{GENETIC AND DEVELOPMENTAL DISORDERS}

The level of serum TBG is genetically determined, and rare cases of congenitally reduced or absent TBG (Ingbar, 1961a; Refetoff and Selenkow, 1966; Nikolai and Seal, 1967; Kraemer and Wiswell, 1968) and congenitally increased TBG (Beierwaltes and Robbins, 1959; Jones and Seal, 1967) have been reported. Euthyroid subjects with a low serum TBG have low serum PBI levels and those with a high serum TBG have a high serum PBI level. A high serum PBI level has been reported in a case of Fanconi's anaemia (London, Drukker, and Sandbank, 1965) and a high TBG capacity in a case of hereditary anhidrotic ectodermal dysplasia (Hippe, 1967), but these associations may have been coincidental.

The determination of the serum PBI has been extensively used to investigate thyroid function in developmental disorders, but abnormal values are rare. One case of a mosaic $\mathrm{XO} / \mathrm{XY} / \mathrm{XXY}$ genotype was reported in association with a defect in thyroglobulin synthesis, a normal serum PBI level, and a low serum $\mathrm{T}_{4}$ (Lizarralde et al, 1966), and one out of four cases of De Lange's syndrome had a low serum PBI, the serum PBI being normal in the other three (Hillman, Hammond, Noé, and Reiss, 1968).

Proven cases of clinical hypothyroidism or hyperthyroidism are extremely rare in mongolism (Hayles, Hinrichs, and Tauxe, 1965). The serum PBI (Fisher et al, 1964; Marks and Hamlin, 1967), TBG capacity (Rimoin, 1965) and free $T_{4}$ (Marks and Hamlin, 1967) in mongols have been reported not to differ significantly from the values in non-mongol control subjects. On the other hand, Dodge, Neill, and Scally (1967) recorded a high proportion of low serum PBI and BEI levels with high PBI-BEI differences in mongols, although they did not report any determinations on control subjects, and Fisher et al (1964) found that the $T_{3}$ resin uptake was significantly higher on average in mongols than in control subjects. These last results might suggest that abnormal TBG or iodoprotein was present in the serum of some mongols, but methodological explanations for the abnormal findings cannot be excluded. Pearse, Reiss, and Suwalski (1963) reported low thyroid ${ }^{131}$ I uptakes in 17 out of 125 male and seven out of 26 female mongols, and a high uptake in one patient. They also stated that diffuse or nodular thyroid enlargements were noted in many of their patients. An association between mongolism and thyroid dyshormonogenesis cannot thus be excluded.

The differentiation of cretins from mongols, from rachitic and chondroplastic dwarfs, from other types of idiots, and from pituitary dwarfs is discussed by Means et al (1963).

Normal serum PBI levels have been reported in Klinefelter's syndrome (Plunkett, Rangecroft, and Heagy, 1964); various mosaic genotypes (Jagiello, Kaminetsky, Ricks, and Ryan, 1966; Lindsten, Bergstrand, Tillinger, Schwarzacher, Tiepolo, Muldal, and Hokfelt, 1966); Turner's syndrome (Freychet, Rosselin, Assan, Tchobroutsky, Dolais, and Dérot, 1967); cerebral gigantism (Stephenson, Mellinger, and Manson, 1968); the Prader-Willi syndrome (Landwirth, Schwartz, and Grunt, 1968); Seckel's syndrome (Harper, Orti, and Baker, 1967; Hillman et al, 1968); and Werner's syndrome (Zucker-Franklin, Rifkin, and Jacobson, 1968).

\section{INFECTIONS}

Data on serum PBI levels are lacking for most common infections. One might expect that disturbances of liver function in infection could lead to abnormalities in the serum PBI as a result of changes in the rate of secretion of TBG and possibly of iodoalbumin. In fact high serum PBI levels and 
TBG capacity have been reported in the acute phase of infective hepatitis (Vannotti and Béraud, 1959; Lemarchand-Béraud, Assayah, and Vannotti, 1964) and an increased scatter of PBI values with both high and low levels in pulmonary tuberculosis (Klassen, Riley, and Curtis, 1945; Cattaneo, de Simoni, and Fantoli, 1955; de Simoni, 1957) and Chagas, disease (Lomonaco, Oliveira, Kieffer, and Pieroni, 1966). A fall of $0 \cdot 5-1 \mu \mathrm{g} / 100 \mathrm{ml}$ coinciding with a rise in the percentage of free $T_{4}$ was observed on the third day of experimental human tularaemia, and a rise of $1-2 \mu \mathrm{g} / 100 \mathrm{ml}$ coinciding with a fall in the percentage of free $T_{4}$ was observed on the fifth day of the disease (Shambaugh and Beisel, 1967). On the other hand, normal serum PBI levels have been reported in pneumococcal pneumonia (Gregerman and Solomon, 1967) and in leprosy (Sehgal and Basu, 1967).

It seems that changes in the serum PBI in infections are inconsistent and may be absent.

\section{IMMUNOLOGICAL DISORDERS}

Abnormal serum PBI levels have not been reported in disorders of immunity unless the thyroid gland is involved in the disease process. The serum PBI is within the normal range in asthma (Dahl, 1964).

\section{NEOPLASTIC DISEASES}

Hormone-secreting tumours may cause increases in the serum protein-bound iodine. Three different mechanisms have been demonstrated: (1) oestrogen secretion in hydatidiform mole (Dowling, Ingbar, and Freinkel, 1960b) producing raised TBG; (2) secretion of thyroid-stimulating hormone (TSH) in some cases of chorionepithelioma (Odell, Bates, Rivlin, Lipsett, and Hertz, 1963) and in one case of embryonic carcinoma of the testis (Steigbigel, Oppenheim, Fishman, and Carbone, 1964); and (3) secretion of thyroid hormone by an ovarian dermoid cyst with struma ovarii (Perlmutter and Mufson, 1951). The serum PBI level is normal in phaeochromocytoma although there is hypermetabolism (Beierwaltes, 1956).

There is no evidence of consistent changes in the serum PBI in patients with tumours which do not secrete hormones. Reports that the serum PBI was high in some cases of metastatic carcinoma of the breast (Carter, Feldman, and Schwartz, 1960; Myhill, Reeve, and Hales, 1966) have not been confirmed (Marczynska, Kolodziejska, Glinska, and Adamczyk, 1965). Data which suggested that hypothyroidism was associated with a marginally increased incidence and a poorer prognosis in malignant disease (Liechty, Hodges, and Burket, 1963) have not been generally accepted as evidence of a relation between neoplasia and thyroid state. Sicher and
Waterhouse (1967) in a careful study found no evidence to suggest that the progress of carcinoma of the breast was related in any way to the thyroid state of the patient, despite the widespread clinical impression to the contrary.

\section{DISORDERS OF METABOLISM}

Hollander et al (1967b) reported abnormalities of serum iodine in acute intermittent porphyria. High serum PBI levels were found in four out of 10 male patients and seven out of 17 female patients; high serum TBG capacity in two out of seven male patients and 11 out of 13 female patients; and a PBI-T $\mathrm{T}_{4} \mathrm{I}$ difference greater than $1 \mu \mathrm{g} / 100 \mathrm{ml}$ in three out of 10 female patients and in three out of five male patients. These results suggest that liver function is disturbed. The high PBI-T $\mathrm{T}_{4} \mathrm{I}$ difference was not commented on by Hollander et al (1967b) but might suggest that the liver was producing abnormal amounts of an iodoprotein similar to that described by Surks and Oppenheimer (1969).

Normal serum PBI levels have been reported in phenylketonuria (Leistyna, Hassan, Aplin, and Green, 1964; Rundle, Fannin, and Sylvester, 1966; Tishler and Ingbar, 1966), in episodic ketotic hypoglycaemia of infants (Colle and Ulstrom, 1964), and in progressive partial lipodystrophy, otherwise known as Barraquer-Simon's disease (Rifkind and Boyle, 1967).

The effect of malnutrition on the serum PBI requires further study. Case reports have appeared of low serum PBI levels in severe malnutrition with hypoalbuminaemia (Peters and Man, 1948), in spinal transection with inanition and hypoalbuminaemia (Lloyd, Kaplan, Kupperman, Grynbaum, and Rusk, 1964), and in a number of chronic debilitating disorders which probably involved poor nutrition (Engstrom and Markardt, 1955). The low serum PBI levels are not the direct result of the low serum albumin, since the serum PBI is normal in hereditary analbuminaemia (Hollander, Bernstein, and Oppenheimer, 1968). The low serum PBI levels might result from depression of the thyroid gland, since it has been reported that thyroid ${ }^{131}$ I uptakes may be low in children suffering from malnutrition (El-Gholmy, Ghaleb, Khalifa, Senna, and ElAkkad, 1967).

The serum PBI is usually normal in obesity (Craig, Ray, Waxler, and Madigan, 1963; Dolecek and Klabusay, 1963; Hortling, de la Chapelle, Frisk, and Widholm, 1964; Benoit and Durrance, 1965). However, a tendency towards low serum PBI levels has been reported in obese patients whose serum free fatty acid level was not reduced by adrenaline (Goldberg and Gordon, 1964). In one group of obese patients fasting lowered the serum PBI level by 
$1 \mu \mathrm{g} / 100 \mathrm{ml}$ and also lowered the thyroid absolute iodine uptake (Alexander, Harrison, Harden, and Koutras, 1964). In another group of obese patients fasting was found not to affect the serum PBI (Schatz, Sheppard, Palter, and Jaffri, 1967). Possibly the level of serum free fatty acids may determine whether a fasting obese patient has a low serum PBI or not, since free fatty acids are known to displace $\mathrm{T}_{4}$ from TBG (Hollander, Scott, Burgess, Rabinowitz, Merimee, and Oppenheimer, 1967a).

Gout is a complication of myxoedema, particularly in postmenopausal women (Leeper, Benua, Brener, and Rawson, 1960; Ryckewaert, Massé, Jurmand, Caroit, Durieu, Guérin, and de Sèze, 1967), and a low serum PBI may thus be of diagnostic importance.

\section{DISEASES OF ENDOCRINE GLANDS OTHER THAN THE THYROID}

The serum PBI may be affected in pituitary disease as a result of disorders in TSH secretion. Hypopituitarism leads to hypothyroidism when the TSH secretion is reduced, but TSH secretion may be spared in some cases so the serum PBI may remain normal (see Wayne et al, 1964; Odell, 1966; Spellacy and Cohen, 1967). Normal serum PBI levels have been reported in Cushing's disease (Oppenheimer and Werner, 1966). Acromegaly has an inconsistent effect on the serum PBI, high, low and normal values having been reported in different patients (Hamwi, Skillman, and Tufts, 1960; Kozac, Vagnucci, Lauler, and Thorn, 1966; Inada and Sterling, 1967a; Roth, Glick, Cuatrecasas, and Hollander, 1967). It appears that patients in the active stage of the disease or who have had the disease for more than five years are the more likely to have low serum PBI levels. This partly results from TSH deficiency and partly from a reduction in TBG capacity (Inada and Sterling, 1967a; Roth et al, 1967). High serum PBI levels in acromegaly would raise the suspicion of thyrotoxicosis, which is known to occur in association with acromegaly (Roth et al, 1967).

Cases of primary Addison's disease have been reported in association with hypothyroidism, Hashimoto's disease, focal lymphocytic thyroiditis, and nodular goitre (Turkington and Lebovitz, 1967), the serum PBI levels being appropriate to the thyroid disorder.

The effect of hormone-secreting ovarian, testicular, and placental tumours on the serum PBI is discussed in the section on neoplastic diseases. The serum PBI is normal in female hirsutism (Wieland, Vorys, Folk, Besch, Neri, and Hamwi, 1966).

Normal serum PBI levels have been reported in testicular deficiency with sexual infantilism (Huffer, Scott, Connor, and Lovice, 1964) and testicular feminization (Walker, Carney, and Gates, 1964). Three cases have been reported in which either ovarian or testicular dysgenesis, multiple congenital abnormalities, and a high level of follicle-stimulating hormone or total gonadotropin excretion were associated with serum PBI levels between 8.3 and $9 \cdot 4$ $\mu \mathrm{g} / 100 \mathrm{ml}$ (Chokas, 1960; Lundberg, 1966). Possibly these patients could have had high TSH secretion rates as a result of the stimulation of pituitary activity by the low level of circulating gonadal hormones, although they were reported as being clinically euthyroid. A case of juvenile hypothyroidism associated with precocious puberty and an ovarian mass which regressed on $\mathrm{T}_{4}$ therapy (Wood, Olichney, Locke, Crispell, Thornton, and Kitay, 1965) may represent an instance of the reverse phenomenon in which the pituitary is stimulated to secrete gonadotropic hormone by the low level of circulating thyroid hormone.

Normal serum PBI levels are found in primary gynaecomastia (Rosewater, Gwinup, and Hamwi, 1965), although gynaecomastia which regresses on antithyroid treatment is commonly present in active thyrotoxicosis (Becker, Winnaker, Matthews, and Higgins, 1968).

DISEASES OF THE DIGESTIVE SYSTEM

Hepatocellular disorders may cause abnormalities of the serum PBI, presumably as a result of disturbances in TBG synthesis and possibly also in $T_{4}$ metabolism. High serum PBI levels are found in the acute phase of infective hepatitis (Vannotti and Béraud, 1959; Lemarchand-Béraud et al, 1964). The serum PBI is usually within normal limits in hepatic cirrhosis (Mueller, Brausch, Hirsch, Benua, and Dobyns, 1954; Shipley and Chudzik, 1957) but occasional results outside the normal range occur, low values being more frequent than high values (Kydd and Man, 1951; Tanaka and Starr, 1959; Bora, Kapoor, Krishnan, and Tandon, 1963; Hollander, Meek, and Manning, 1967c; Inada and Sterling, 1967b).

The serum PBI is normal in obstructive jaundice (Kydd and Man, 1951), acute alcoholism (Selzer and vanHouten, 1964; Augustine, 1967), chronic alcoholism (Selzer and vanHouten, 1964), and pancreatic steatorrhoea (Hiss and Dowling, 1962).

Thyrotoxicosis may present with abdominal pain and vomiting, simulating an acute abdomen (Chapman and Maloof, 1956).

DISEASES OF THE HAEMOPOIETIC SYSTEM

The serum PBI has been reported to be raised in some cases of acute or chronic leukaemia of both lymphocytic and myelocytic types (Shurygin, Komarova, Murchakova, Sokolova, and Tendler, 1967). 
This finding requires confirmation since it has been generally accepted that thyroid function is normal in leukaemia despite hypermetabolism (Means et al, 1963). Fractionation studies of blood iodine would be of interest to investigate whether abnormal quantities of iodoproteins were present in leukaemia.

The association between pernicious anaemia and hypothyroidism (Irvine, Davies, Delamore, and Wynn-Williams, 1962), thyrotoxicosis (Doniach, Roitt, and Taylor, 1963) or Hashimoto's disease (Irvine et al, 1962) is well known.

DISEASES OF THE CARDIOVASCULAR SYSTEM Unexplained low PBI values have been reported in some inpatients with atherosclerosis (Janotka, Ondrejička, and Pechán, 1967). Normal values have been found in hypertension (Mehbod, Swartz, and Brest, 1967), congestive cardiac failure in euthyroid patients not treated with diuretics (Mehbod, Swartz, and Brest, 1967), idiopathic atrial fibrillation (Peter, Gracey, and Beach, 1968), supraventricular tachycardia (Schatz, 1967), and myocardial infarction (Volpé et al, 1960), the last observation not confirming an earlier report of low serum PBI levels in some patients with myocardial infarction (Marmorston, Hoffman, Sobel, and Starr, 1955).

Congestive cardiac failure is a well known complication of thyrotoxicosis (Means et al, 1963) and myxoedema heart is also well known (Means et al, 1963). An association between hypothyroidism with hypercholesterolaemia and coronary artery disease has been suggested (Azar, 1965).

\section{DISEASES OF THE KIDNEYS}

In the nephrotic syndrome the serum PBI is often low when the serum protein disorder is severe, but normal serum PBI levels may occur (Peters and Man, 1948; Perry and Cosgrove, 1949; Kydd, Man, and Peters, 1950; Recant and Riggs, 1952; Rasmusson, 1956; Robbins and Rall, 1957; Robbins, Rall, and Petermann, 1957; Cruchaud, Béraud, Cruchaud, and Vannotti, 1958). The patients tend to be hypometabolic but are not clinically hypothyroid, and appear to have normal rates of $T_{4}$ synthesis although the absolute rate of tissue metabolism of $T_{4}$ may be low with large urinary losses of $T_{4}$ and TBG (Rasmusson, 1956; Cruchaud et al, 1958).

In chronic renal failure with uraemia the serum PBI is usually normal, although a few cases with low levels have been reported, possibly as a terminal event (Perry and Hughes, 1952; Engstrom and Markardt, 1955).

\section{DISEASES OF THE LOCOMOTOR SYSTEM AND} SKELETON

Epiphyseal dysgenesis and retarded bone growth are recognized complications of juvenile hypothyroidism (Means et al, 1963). Signs of thyroid hypofunction or the presence of toxic thyroid adenomas were stated to have been found by isotope studies in seven out of seven patients with Legg-Calvé-Perthes disease (Emerick, Holly, Joistad, and Corrigan, 1954) but normal serum levels were reported in 31 out of another series of 32 cases, the remaining patient having a high serum PBI (Katz, 1955). The existence of an association between Legg-Calvé-Perthes disease and juvenile thyroid disease thus remains an open question.

Osteoporosis with pathological fractures and bone destruction or osteitis fibrosa may occur in the later stages of untreated thyrotoxicosis (Means et al, 1963).

Subacromial bursitis occurs in $4 \%$ of patients with thyrotoxicosis (Chapman and Maloof, 1956).

\section{DISEASES OF THE SKIN}

Although de Mowbray and Tickner (1952) reported low serum PBI levels in nine out of 50 patients with miscellaneous skin disorders, there is no evidence that abnormal serum PBI levels are associated with any particular skin disease. Normal serum PBI levels have been reported in both male and female types of alopecia (Lubowe, 1963).

The skin changes in hypothyroidism and in thyroid acropachy are well documented (Means et al, 1963). Peripheral oedema, unaccompanied by renal or circulatory failure, is a rare manifestation of thyrotoxicosis (Chapman and Maloof, 1956; Means et al, 1963).

DISEASES OF THE NEUROMUSCULAR SYSTEM Normal serum PBI levels have been usually found in primary disorders of muscle function, such as progressive muscular dystrophy (Danowski, Sabeh, Vester, Sarver, and Sunder, 1965), and myotonia dystrophica, which is only rarely associated with hypothyroidism, although hypometabolism is present (Stanbury, Goldsmith, and Gillis, 1954; Jacobson, Schultz, and Anderson, 1955; Holland and Hill, 1956). High serum PBI levels were reported in two out of eight patients with ocular myopathy (Lundberg, 1966), but the patients had gonadal dysgenesis and congenital developmental disorders in addition. It is thought more likely that the high serum PBI levels in these patients were related to endocrine imbalance, and they have been discussed in the section on endocrine disease.

Severe myopathy occurs in some thyrotoxic patients (Chapman and Maloof, 1956; Means et al, 1963). The sporadic type of periodic paralysis is associated with thyrotoxicosis (Engel, 1961). Myasthenia gravis is also associated with thyrotoxicosis 
(Grob, 1958; Szobor and Környey, 1966). In one such myasthenic and thyrotoxic patient, who was on $T_{4}$ maintenance therapy after treatment of the thyrotoxicosis by ${ }^{131} \mathrm{I}$, the myasthenia was exacerbated by any departure from euthyroidism towards either hypothyroidism or hyperthyroidism (Gaelen and Levitan, 1968).

Myxoedema patients may present with a myopathy characterized by muscular stiffness and pain (Means et al, 1963).

The serum PBI was found to be normal in patients with Parkinsonism of various aetiologies, although clinically they presented some features of hypothyroidism (Strang, 1968). Normal serum PBI levels have been reported in kuru (Buttfield, Hetzel, and Hornabrook, 1968). Some cases have been reported of diencephalic and hypothalamic tumours associated with signs of hypothyroidism (Buntser, 1965), presumably secondary to disturbances of pituitary function.

Thyrotoxicosis may present as an encephalopathy or an epileptiform seizure (Chapman and Maloof, 1956).

The carpal tunnel syndrome may be a presenting feature of myxoedema (Means et al, 1963).

\section{DISEASES OF THE EYE}

High serum PBI levels have been observed in superior limbic keratoconjunctivitis (Tenzel, 1968; Theodore, 1968; Cher, 1968), a condition which may be associated with hyperthyroidism or previous hyperthyroidism (Cher, 1968). Superior rectus palsy is an early sign of dysthyroid exophthalmos (Goldstein, 1964).

\section{MENTAL DISORDERS}

Evidence of thyroid dysfunction has been sought in mental disorders of various types for many years, but the results have usually been negative. Difficulty arises in this field because groups of patients with the same diagnosis studied by different workers are not necessarily representative of the same clinical entity. Normal serum PBI levels have been reported in toxic psychosis (Bowman, Miller, Dailey, Simon, Frankel, and Lowe, 1950), schizophrenia (Brody and Man, 1950; Bowman et al, 1950; Simpson, Cranswick, and Blair, 1964), manic depression (Bowman et al, 1950), periodic psychosis (Libow and Durell, 1965), depression (Board, Wadeson, and Persky, 1957; Gibbons, Gibson, Maxwell, and Wilcox, 1960; Nikula-Baumann, Hiisi-Brummer, and Baumann, 1965), mixed psychoneurosis (Bowman et al, 1950), and anorexia nervosa (Bowman et al, 1950; de Moor and Evenepoel, 1964). The serial PBI measurements in patients with catatonia reported by Gjessing (1964) are difficult to interpret because his patients were treated with seaweed and $T_{3}$ and $T_{4}$ loads at different stages of his investigation.

Recently, abnormal serum PBI levels have been reported in some patients suffering from affective disorders or from schizophrenia with a high paranoid rating and marked emotional stress (ParhonStefanescu, Nikolau, Aurora, Kuku, and Vianu, 1966; Dewhurst, El Kabir, Exley, Harris, and Mandelbroke, 1968; Gosling, 1968). ParhonStefanescu et al (1966) recorded low serum PBI levels in four out of 16 endogenous depressives, four out of 11 reactive depressives, five out of eight involutional depressives, and 13 out of 27 patients in the depressive phase of manic depression. Dewhurst et al (1968) reported that eight out of 20 schizophrenics had at least one high serum PBI reading and five out of the 20 had at least one high blood TSH level, associated with a high paranoid rating. On the other hand, one of their schizophrenics had a persistently low serum PBI level. Dewhurst et al (1968) also reported at least one high serum PBI level in 17 out of 44 patients with affective disorders. Of those 17 patients, 11 were in the initial stages of depression. At least one high blood TSH level was found in 16 of the 44 patients, of whom 15 patients were suffering from depression and one from hypomania. Dewhurst et al (1968) reported that high TSH levels and high PBI levels were not always found in the same blood sample and suggested that changes in TBG capacity might have occurred in some of their patients. Nevertheless they concluded that emotional stress in psychiatric patients might increase TSH secretion. Gosling (1968) stated that elderly patients with agitated depression tended to have high serum PBI levels, which fell on remission of the psychiatric disorder. On the other hand, Libow and Durell (1965) described a schizophrenic patient with a periodic psychosis, whose serum PBI and thyroid ${ }^{131}$ I uptake tended to rise on transition from hyperactivity to muteness, and vice versa, presumably as a result of changes in TSH secretion rate.

Parhon-Stefanescu et al (1966) did not report any studies of thyroid function in their patients other than the serum PBI, and it is possible that hypothyroidism was an aetiological or precipitating factor in the psychiatric disorders of their patients with low serum PBI levels. This may also have been the case in the schizophrenic with a low serum PBI reported by Dewhurst et al (1968). The finding by Dewhurst et al (1968) of high serum PBI levels in emotionally stressed psychiatric patients is consistent with the study of Levi (1967) in which severe emotional stress caused significant elevation of serum PBI in normal subjects. Gosling (1968) suggested that the thvroid reserve might fall as a result of 
continued stimulation over a long period in agitated depressives.

The onset of an attack of thyrotoxicosis is often associated with a history of recent psychological trauma (see Means et al, 1963) and severe mental disorders may occur in myxoedema in adults, both untreated and on commencing $T_{4}$ therapy (see Means et al, 1963).

\section{Drugs which May Affect the Serum PBI}

Drugs which alter the serum PBI level may be grouped into seven classes: (1) goitrogens, (2) drugs which affect $T_{4}$ transport, (3) drugs which affect the uptake and metabolism of $T_{4}$ by tissues, (4) drugs used in thyroid replacement therapy, (5) other drugs which contain iodine, (6) drugs which interfere with the chemistry of PBI determinations, and (7) drugs which have been reported to affect the serum PBI without elucidation of the mechanism responsible. It is also helpful for diagnostic purposes to know if a drug has been shown not to affect the serum PBI level.

The widespread use of the red dye, erythrosine (tetra-iodofluorescein), to colour proprietary pharmaceuticals is a serious source of contamination (Andersen, Keiding, and Nielsen, 1964; Bora, Radichevich, and Werner, 1969). Enquiry should be made whether the patient is taking any red-coloured preparations before taking blood for a serum PBI estimation.

The effect of drugs on the serum PBI is discussed in general terms in this section. Supplementary information on specific products is included in the Appendices.

\section{GOITROGENS}

Goitrogenic substances interfere with the synthesis of thyroid hormone, thereby causing hypothyroidism with a low serum PBI level. The development of goitre results from an increase in the secretion of thyroid-secreting hormone. Goitrogenic drugs are of two main types (Wayne et al, 1964). The first type, of which perchlorate is an example, interferes with the trapping of iodide by the thyroid gland. The second type, of which thiouracil is an example, inhibits the iodination of tyrosine residues in thyroglobulin. Several of the more powerful goitrogens are used for the medical treatment of thyrotoxicosis.

DRUGS AFFECTING T 4 TRANSPORT IN SERUM Drugs may affect the $T_{4}$-binding capacity of serum in three ways. They may cause an increase, eg, oestrogens (Dowling, Freinkel, and Ingbar, 1956b) or a decrease, eg, androgens (Federman, Robbins, and Rall, 1958) in the number of serum $T_{4}$-binding $\stackrel{D^{\circ}}{\overrightarrow{0}}$ sites, or they may compete with $T_{4}$ for the existing $\mathrm{T}_{4}$-binding sites, eg, salicylates (Austen, Rubini, $\overrightarrow{\vec{F}}$ Meroney, and Wolff, 1958). Drugs which reduce $\stackrel{5}{+}$ serum $T_{4}$-binding capacity or which compete with $\mathrm{T}_{4}$ for binding sites may cause low serum PBI levels to be found in euthyroid individuals, whereas drugs which increase $T_{4}$-binding capacity may give rise to $\triangle$ high scrum PBI levels in euthyroid individuals.

\section{DRUGS ALTERING THE UPTAKE AND}

METABOLISM OF T, BY TISSUES

It has been found that diphenylhydantoin, which competes with $T_{4}$ for TBG (Oppenheimer and 8 Tavernetti, 1962), also causes a reduction in the i absolute free $T_{4}$ concentration. Chin and Schussler $\dot{\omega}$ (1968) suggested that diphenylhydantoin increased the rate of uptake and degradation of $T_{4}$ by the liver (see also Oppenheimer, Bernstein, and Hasen, 1967). 은 Hersham (1964) reported that 5-propylthouracil and $\rightarrow$ 6-propylthouracil increased the serum PBI of $\frac{7}{0}$ patients being treated with $T_{4}$ and perchlorate by $0.8 \mu \mathrm{g} / 100 \mathrm{ml}$, presumably by reducing peripheral metabolism of $T_{4}$.

\section{DRUGS USED IN THYROID REPLACEMENT THERAPY}

Serum PBI levels in patients on thyroid maintenance therapy are usually within normal limits if desiccated thyroid is used, high if $T_{4}$ alone is used, and low if $T_{3}$ alone is used (Lavietes and Epstein, 1964; Alley, Danowski, Robbins, Weir, Sabeh, and Moses, 1968). $T_{4}$ is more strongly bound to TBG than $T_{3}$, hence $T_{3}$ is more active in physiological conditions than $T_{4}$ (Oppenheimer et al, 1963). The serum concentration of $T_{3}$ required to maintain a subject in the euthyroid state is thus less than the corresponding serum concentration of $T_{4}$. Desiccated thyroid provides a thyroid hormone preparation in which the ratio of $T_{3}$ to $T_{4}$ approximates to that of the normal thyroid secretion and normal PBI levels are usually found when these preparations are used. In the case of one thyroid preparation (Proloid), administration of adequate maintenance doses was $ᄋ$ associated at one time with low PBJ levels, perhaps $N$ because the method of preparation then in use N resulted in a high $T_{3}$ content (Braverman and Ingbar, 1964).

The possibility exists that a thyroid preparation given orally could cause a temporary elevation of $\stackrel{\mathbb{P}}{\rightarrow}$ serum PBI which would be sufficiently large to give misleading results. Myant and Pochin (1950) found 0 that after an oral dose of $80 \mu \mathrm{g}$ of [131I] $\mathrm{T}_{4}$, a maximum of 4 to $5 \%$ of the dose was present per litre of $\stackrel{\odot}{\mathbb{D}}$ plasma, the peak activity occurring two to three hours after administration and falling off very 
slowly over 24 hours. An oral dose of $0.3 \mathrm{mg}$ of $\mathrm{T}_{4}$ would thus be expected to raise the serum PBI by $1.5-2 \mu \mathrm{g} / 100 \mathrm{ml}$ after two to three hours. This effect is not large enough to be responsible for the high PBI levels in $\mathrm{T}_{4}$-treated patients, but should be borne in mind in interpreting serial variations in the serum PBI of these patients.

\section{IODINE-CONTAINING PREPARATIONS OTHER}

THAN THYROID MEDICATIONS

Iodine drugs may cause high serum PBI levels if they contain sufficient iodine in a form which is precipitable with serum proteins. These products mostly fall into one of the following groups: (1) radiographic contrast media, (2) amoebicides and intestinal disinfectants, (3) expectorants, (4) topical applications (lotions, ointments, skin disinfectants, and cosmetics), and (5) vitamin-mineral preparations.

Organic iodine compounds which are precipitated with the serum PBI are often protein-bound and long-acting (Heijdemann and Lindeboom, 1958). Some are metabolized and may cause elevations of plasma inorganic iodide (Chaney, 1958), which lead to a reduced thyroid ${ }^{131}$ I uptake (Sendrail, Bru, and Bloom, 1966).

Preparations containing relatively small doses of inorganic iodide reduce the thyroid ${ }^{131}$ I uptake without affecting the serum PBI (Slater and Numeroff, 1961). Doses of $1 \mathrm{~g}$ of iodide per day increase the serum PBI (Fisher et al, 1965). Heavier dosage over a long period leads to iodide goitre (see above) associated with the presence of an abnormal serum iodoprotein (Danowski et al, 1950).

The effect of inorganic iodide on the serum PBI usually lasts a few weeks. Organic iodine compounds may persist longer in the serum. Radiographic contrast media are particularly troublesome. Elevations following intravenous pyelography tend to persist for several days or a few weeks, those following cholecystography persist for months up to many years with transplacental contamination in the case of Teridax, and those following bronchography or myelography persist for many years (see reviews by Sisson, 1965; and Davis, 1966). Placental arteriography within 14 days of birth has been reported to cause a raised serum PBI in the neonate for six to eight months (Similä, Rosberg, and Pystynen, 1967).

\section{INTERFERENCE WITH THE ANALYTICAL} METHOD

Heavy metals are the most important source of interference with the chemistry of PBI determinations. Mercury and its salts interfere with the digestion and distillation steps in wet ashing methods and with the catalytic determination of iodide by the ceric-arsenite reaction (Myers and Man, 1951; Zak,
Willard, Myers, and Boyle, 1952). The administration of mercurial diuretics to the patient may cause low results to be obtained in PBI analyses performed by the acid distillation or chloric acid digestion techniques (Myers and Man, 1951; Zak et al, 1952). A 24-hour period following the administration of the drug is usually sufficient to allow the drug level to decrease below the interference level, although 48 hours may be necessary to allow excretion of the drug if the diuretic is unsuccessful (Myers and Man, 1951; Barker, 1955). Schteingart, Perlmutter, and Numeroff (1960) found a mean decrease of $0.24 \mu \mathrm{g} /$ $100 \mathrm{ml}$ in the serum PBI four hours after a dose of meralluride when using an alkaline ashing method, but there was no residual effect after longer periods. The difference at four hours was not statistically significant, but the results of Schteingart et al (1960) do nct exclude interference by mercurials with PBI determinations by alkaline ashing. It is theoretically possible that mercuric iodide could be volatilized at the temperatures used for alkaline ashing $\left(600^{\circ} \mathrm{C}\right)$. The degree of protein binding of the mercurial might also be a factor in determining whether it would interfere with the analysis.

Therapy with gold salts causes very low serum PBI levels determined by the chloric acid digestion method because gold salts interfere with the cericarsenite reaction which is used to estimate iodine in the digest (Fisher, Levy, and Price, 1965). Presumably similar interference would occur if an alkaline ashing method was used.

Copper in distilled water may interfere with PBI determination by acid digestion according to Means et al (1963), but it is not clear from their statement whether the digestion or the estimation step is affected.

I was greatly helped in compiling the data on nonthyroid diseases and on drugs by two Medlars searches carried out by the National Lending Library for Science and Technology, Boston Spa, Yorks. I wish to thank Professor J. Crooks for reading and commenting on the manuscript. The preparation of this review was assisted by a grant from the Research and Teaching Fund of the Central Middlesex Hospital Group.

\section{References}

Ackerman, N. B., and Arons, W. L. (1958). The effect of epinephrine and norepinephrine on the acute thyroid release of thyroid hormones. Endocrinology, 62, 723-737.

Acland, J. D. (1957). The estimation of serum protein-bound iodine by alkaline incineration. Biochem. J., 66, 177-188.

Acland, J. D. (1958). The nature, determination and clinical importance of blood iodine: a review. J. clin. Path., 11, 195-205.

Alexander, N. M. (1959). Antithyroid action of 3-amino-1,2,4triazole. J. biol. Chem., 234, 148-150. 
Alexander, R. W., and Marmorston, J. (1961). Effect of two synthetic estrogens on the level of serum protein-bound iodine in men and women with atherosclerotic heart disease. J. clin. Endocr., 21, 243-251.

Alexander, W. D., Harrison, M. T., Harden, R. McG., and Koutras, D. A. (1964). The effect of total fasting on thyroid function in man. Metabolism, 13, 587-590.

Alley, R. A., Danowski, T. S., Robbins, T. J. L., Weir, T. F., Sabeh, G., and Moses, C. L. (1968). Indices during administration of $T_{4}$ and $T_{3}$ to euthyroid adults. Metabolism, 17, 97-104.

Anbar, M., Guttmann, S., and Lewitus, Z. (1959). The mode of action of perchlorate ions on the iodine uptake of the thyroid gland. Int. J. appl. Radiat., 7, 87-96.

Andersen, C. J., Keiding, N. R., and Nielsen, A. B. (1964). False elevation of serum protein-bound iodine caused by red colored drugs or foods. Scand. J. clin. Lab. Invest., 16, 249.

Andreoli, M., and Luca, F. de (1964). Effetti su la captazione tiroidea del radioiodio e la iodioprotidemia del 2-etil-(3,5-diiodo-4idrossi-benzoil)-3-benzofurano. Clin. ter., 31, 42-45.

Augustine, J. R. (1967). Laboratory studies in azute alcoholics. Canad. med. Ass. J., 96, 1367-1370.

Austen, F. K., Rubini, M. E., Meroney, W. H., and Wolff, J. (1958). Salicylates and thyroid function. I. Depression of thyroid function. J. clin. Invest., 37, 1131-1143.

Austin, E., and Koepke, J. A. (1966). An automated procedure for total organic iodine. Amer. J. clin. Path., 45, 344-347.

Azar, G. J. (1965). The serum protein-bound iodine level in acute myocardial infaretion. J. Amer. Geriat. Soc., 13, 212-221.

Barker, D. J. P., and Bishop, J. M. (1969). Computer-based screening system for patients at risk of hypothyroidism. Lancet, 2, 835838.

Barker, S. B. (1955). Personal communication.

Bax, G. M. (1966). Typical and atypical cases of Pendred's syndrome in one family. Acta endocr. (Kbh.), 53, 264-270.

Becker, K. L., Katz, S., and Miale, A., Jr. (1967). Tetracycline and thyroid function. J. Amer. med. Ass., 199, 416-417.

Becker, K. L., Winnacker, J. L., Matthews, M. J., and Higgins, G. A., Jr. (1968). Gynecomastia and hyperthyroidism. An endocrine and histological investigation. J. clin. Endocr., 28, 277-285.

Beierwaltes, W. H. (1956). The value of radioactive iodine uptake and protein-bound iodine estimations in the diagnosis of thyrotoxicosis. Ann. intern. Med., 44, 40-51.

Beierwaltes, W. H. (1965). Thyroiditis. Ann. N.Y. Acad. Sci., 124, 586-604.

Beierwaltes, W. H., and Robbins, J. (1959). Familial increase in the thyroxine-binding sites in serum alpha globulin. J. clin. Invest., 38, 1683-1688.

Bellabarba, D., and Sterling, K. (1969). Formation of esters of thyroxine and triiodothyronine during alcoholic extraction. J. clin. Endocr., 29, 1510-1513.

Bender, C. E., Fitzgerald, L. T., and Williams, C. M. (1968). Probability values for protein bound iodine, thyroid $\mathrm{I}^{131}$ uptakes and $\mathrm{T}_{3}$ resin uptakes for hypothyroidism, euthyroidism and hyperthyroidism. Amer. J. Roentgenol., 103, 886-893.

Benedek, T. G. (1962). Goiter formation as a result of therapy with phenylbutazone and vitamin A. J. clin. Endocr., 22, 959-962.

Benoit, F. L., and Durrance, F. Y. (1965). Radiothyroxine turnover in obesity. Amer. J. med. Sci., 249, 647-653.

Berg, G. R., Utiger, R. D., Schalch, D. S., and Reichlin, S. (1966). Effect of central cooling in man on pituitary-thyroid function and growth hormone secretion. J. appl. Physiol., 21, 1791-1794.

Berson, S. A., and Yalow, R. S. (1952). The effect of cortisone on the iodine accumulating function of the thyroid gland in euthyroid subjezts. J. clin. Endocr., 12, 407-422.

Blomgren, S. E., and Ansfield, F. J. (1965). Thyroid status following prolonged therapy with fluoropyrimidines. J. Amer. med. Ass., 193, 51 .

Blomstedt, B., and Einhorn, J. (1965). Effect of cortisone on the peripheral degradation of ${ }^{131}$ I-thyroxine. J. clin. Endocr., 25, 181188.

Blomstedt, B., and Einhorn, J. (1967). Effect of cortisone on the PBI and the resin uptake of $\mathbf{I}^{131}$-triiodothyronine. Metabolism, 16, 319-323.

Board, F., Wadeson, R., and Persky, H. (1957). Depressive affect and endocrine functions. Arch. Neurol. Psychiat. (Chic.), 78, 612620.

Bodansky, O., Benua, R. S., and Penacchia, G. (1958). A rapid procedure for determination of total and protein-bound iodine in serum. Amer. J. clin. Path., 30, 375-383.
Bondy, P. K. (1951). Effect of iodothiouracil on the serum proteinbound iodine. J. clin. Endocr., 11, 1406.

Bora, S. S., Kapoor, K. C., Krishnan, P. S., and Tandon, O. P. (1963). Protein-bound iodine in cirrhosis liver. J. Indian med. Ass., 41, 176-179.

Bora, S. S., Radichevich, I., and Werner, S. C. (1969). Artifactual elevation of PBI from an iodinated dye used to stain medicinal capsules pink. J. clin. Endocr., 29, 1269-1271.

Botkin, A. L., and Jensen, H. (1952). The effect of epinephrine and thyrotropin on thyroid function in rats. Endocrinology, 50, 68-72.

Bourquin, M. (1967). Zur Wirksamkeit von Insidon bei zehn Patienten mit Hyperthyreose. Praxis, 56, 769-773.

Bowman, K. M., Miller, E. R., Dailey, M. E., Simon, A., Frankel, B. and Lowe, G. W. (1950). Thyroid function in mental disease measured with radioactive iodine, $\mathrm{I}^{131}$. Amer. J. Psychiat., 106, 561-572.

Braverman, L. E., Foster, A. E., and Ingbar, S. H. (1967a). Sexrelated differences in the binding in serum of thyroid hormones. J. clin. Endocr., 27, 227-232.

Braverman, L. E., Foster, A. E., and Mead, L. W. (1967b). The charcoal $\mathrm{T}_{3}$ ratio. An in vitro test of thyroid function. J. Amer. med. Ass., 199, 469-472.

Braverman, L. E., and Ingbar, S. H. (1964). Anomalous effects of certain preparations of desiccated thyroid on serum proteinbound iodine. New Engl. J. Med., 270, 439-442.

Braverman, L. E., and Ingbar, S. H. (1967). Effects of norethandrolone on the transport in serum and peripheral turnover of thyroxine. J. clin. Endocr., 27, 389-396.

Braverman, L. E., Perkins, W. A., Regnante, R. M., and Coté, R. (1968). The Schiller test and serum protein bound iodine. Amer. J. Obstet. Gynec., 100, 306-307.

Brody, E. B., and Man, E. B. (1950). Thyroid function measured by serum precipitable iodine determinations in schizophrenic patients. Amer. J. Psychiat., 107, 357-359.

Brown, C. H., Lowenstein, J. M., Greenspan, F. S., and Mangum, J. (1966). Effect of stimulation and suppression of the thyroid gland upon production of iodoprotein in man. Metabolism, $15,649-660$.

Brown, J., and Solomon, D. H. (1956). Effects of tolbutamide and carbutamide on thyroid function. Metabolism, 5, 813-819.

Bull, G. M., and Fraser, R. (1950). Myxoedema from resorcinol ointment applied to leg ulcers. Lancet, 1, 851-855.

Buntser, I. M. (1965). A study of protein-bound iodine of the blood in patients with cerebral tumors. (Russian.) Med. Radiol. (Mosk.), $10(1), 5-11$.

Burdick, C. O., and Brown, R. K. (1968). Protein-bound iodine variations. A study in some populations of the Western Pacific. Arch. intern. Med., 121, 54-56.

Burdick, R. E., and Brice, L. T. (1968). Hypothyroidism after sulphonylurea. Lancet, 1, 97.

Burke, G., Silverstein, G. E., and Sorkin, A. I. (1967). Effect of longterm sulfonylurea therapy on thyroid function in man. Metabolism, 16, 651-657.

Buttfield, I. H., Black, M. L., Hoffmann, M. J., Mason, E. K., Wellby, M. L., Good, B. F., and Hetzel, B. S. (1966). Studies of the control of thyroid function in endemic goiter in Eastern New Guinea. J. clin. Endocr., 26, 1201-1207.

Buttfield, I. H., Hetzel, B. S., and Hornabrook, R. W. (1968). Kuru: the endocrine status. Aust. Ann. Med., 17, 20-22.

Cameron, C., and Fletcher, K. (1959). An iodine compound associated with albumin in the plasma of thyrotoxic patients. $N$ Nature (Lond.), 183, 116.

Carter, A. C., Feldman, E. B., and Schwartz, H. L. (1960). Levels of serum protein-bound iodine in patients with metastatic carcinoma of the breast. J. clin. Endocr., 20, 477-480.

Cassidy, C. E., Benotti, J., and Peno, S. (1968). Clinical evaluation of the determination of thyroxine iodine. J. clin. Endocr., 28, $420-421$.

Castrén, O., Laakso, L., and Nikkari, T. (1969). The ${ }^{131}$ I-triiodothyronine-resin uptake test during labour. Acta obstet. gynec. scand., 48, 27-33.

Cattaneo, C., Simoni, G. de, and Fantoli, U. (1955). Il comportamento dello jodio sierico precipitabile prima e dopo intervento chirurgico su sogetti affetti da tubercolosi polmonare. Progr. med. (Napoli), 11, 481-484.

Cavalieri, R. R. (1961). Hyperthyroidism and decreased thyroxine binding by serum proteins. J. clin. Endocr., 21, 1455-1468.

Chaney, A. L. (1958). Protein-bound iodine. Advanc. clin. Chem., 1, 81-109.

\section{.}


Chang, Y. H., Pinson, R., Jr., and Malone, M. H. (1967). Displacement of L-thyroxine from its binding proteins in human, dog, and rat plasma by $a$-( $p$-chlorophenoxy) isobutyric acid. Biochem. Pharmacol., 16, 2053-2055.

Chapman, E. M., and Maloof, F. (1955). The use of radioactive iodine in the diagnosis and treatment of hyperthyroidism: ten years' experience. Medicine (Baltimore), 34, 261-321.

Chapman, E. M., and Maloof, F. (1956). Bizarre clinical manifestations of hyperthyroidism. New Engl. J. Med., 254, 1-5

Cher, 1. (1968). Comments on Tenzel (1968). Arch. Ophthal., 80, 416.

Chin, W., and Schussler, G. C. (1968). Decreased serum free thyroxine concentration in patients treated with diphenylhydanotin. J. clin. Endocr., 28, 181-186.

Chokas, W. V. (1960). Gonadal dysgenesis, rheumatoid spondylitis, hypertension and multiple congenital anomalies. Amer. $J$. Med., 28, 963-968.

Christensen, L. K. (1959). The metabolic effect of salicylate and other hydroxybenzoates. Acta pharmacol. (Kbh.), 16, 129-135.

Clark, F., and Horn, D. B. (1965). Assessment of thyroid function by the combined use of the serum protein-bound iodine and resin uptake of ${ }^{131}$ I-triiodothyronine. J. clin. Endocr., 25, 39-45.

Clements, F. W. (1960). Health significance of endemic goitre and related conditions. Wld Hith Org. Monogr. Ser., 44, 235-260.

Coenegracht, J., and Postmes, T. (1967). Non-iodine containing compounds and ( $\left.{ }^{127} \mathrm{I}\right)$ iodotyrosine-like substances studied by paperand thin-layer chromatography. Clin. chim. Acta, 16, 432-435.

Colle, E., and Ulstrom, R. A. (1964). Ketotic hypoglycemia. J. Pediat. $64,632-651$.

Craig, L. S., Ray, R. E., Waxler, S. H., and Madigan, H. (1963). Chorionic gonadotropin in the treatment of obese women. Amer. J. clin. Nutr., 12, 230-234.

Cranswick, E. H., and Simpson, G. M. (1963). Perphenazine and thyroid function. J. Amer. med. Ass., 186, 1102.

Cranswick, E. H., and Simpson, G. M. (1964). Perphenazine and thyroid function. Amer. J. Psychiat., 120, 1133-1134.

Cruchaud, S., Béraud, T., Cruchaud, J., and Vannotti, A. (1958). Etude du métabolisme de la thyroxine dans un cas de syndrome néphrotique. Schweiz. med. Wschr., 88, 610-613.

Current, J. V., Hales, I. B., and Dobyns, B. M. (1960). The effect of 2,3-dimercaptopropanol (BAL) on thyroid function. J. clin. Endocr., 20, 13-20.

Cushman, P., Jr., Alter, S., and Hilton, J. G. (1965). Effects of clomiphene on oestradiol alterations in thyroxine and cortisol transport in man. Acta endocr. (Kbh.), 50, 329-334.

Czerniak, P., and Harell-Steinberg, A. (1957). The chronology of events in the development of subacute thyroiditis, studied by radioactive iodine. J. clin. Endocr., 17, 1448-1453.

Dahl, S. (1964). Research on serum iron, serum copper, proteinbound iodine, and the secretions of 5-HIAA and 17-ketosteroids in adult patients with allergic asthma. Z. Immun.-Allergieforsch., 127, 95-128.

Danowski, T. S., Huff, S. J., Erhard, L. H., Price, M., Brown, M., Wirth, P., and Stevenson, S. S. (1952). Protein-bound iodine levels in normal and in diabetic children. Amer. J. Dis. Child. 84, 5-10.

Danowski, T. S., Johnston, S. Y., and Greenman, J. H. (1950). Alterations in serum iodine fractions induced by the administration of inorganic iodide in massive dosage. J. clin. Endocr., 10, 519-531.

Danowski, T. S., Johnston, S. Y., Price, W. C., McKelvy, M., Stevenson, S. S., and McCluskey, E. R. (1951). Protein-bound iodine in infants from birth to one year of age. Pediatrics, 7, 240-244.

Danowski, T. S., Moses, C., and Mateer, F. M. (1962). Hydrocortisone and/or desiccated thyroid in physiologic dosage. IV. Serum protein-bound iodine and other thyroid hormone indices. Metabolism, 11, 679-688.

Danowski, T. S., Sabeh, G., Vester, J. W., Sarver, M. E., and Sunder, J. H. (1965). Muscular dystrophy. XI. Trials of 1-methyl- $\Delta^{1}$ androstenolone and digitoxin. Arch. intern. Med., 115, 294-301.

Danowski, T. S., Sarver, M. E., Moses, C., and Bonessi, J. V. (1964). $O-p-D D D$ therapy in Cushing's syndrome and in obesity with Cushingoid changes. Amer. J. Med., 37, 235-250.

Danowski, T. S. Wirth, P., Black, M. H., Barton, E., and Bastiani, R. M. (1955). Effect of vitamin A supplements on serum PBI level, and disposal of exogenous thyroxine. J. clin. Endocr., 15, 1262-1269.

Davies, L. E. C., and Hanson, S. (1965). The Eskimos of the Northwest Passage: A survey of dietary composition and various blood and metabolic measurements. Canad. med. Ass. J., 92, 205-216.
Davis, P. J. (1966). Factors affecting the determination of the serum protein-bound iodine. Amer. J. Med., 40, 918-940.

De Groot, L. J., and Stanbury, J. B. (1959). The syndrome of congenital goiter with butanol-insoluble serum iodine. Amer. J. Med., 27, 586-595.

De Moor, P., and Evenepoel, C. (1964). Studie van 17 gevallen van anorexia nervosa. Ned. T. Geneesk, 108, 2485-2489.

De Mowbray, R. R., and Tickner, A. (1952). The diagnostic value of estimations of protein-bound iodine in serum. Lancet, 2, 511515.

De Pascale, A. (1956). La iodoprotidemia nell' infanzia. Lattante, 27, 84-91.

De Simoni, G. (1957). Il comportamento dello jodio sierico precipitabile e della colesterolemia in soggetti affetti da tubercolosi polmonare trattati con pirazinamide. Minerva med., 48, 404407.

De Visscher, M., Beckers, C., Schrieck, H. G. van den, Smet, M. de, Ermans, A. M., Galperin, H., and Bastenie, P. A. (1961). Endemic goiter in the Uele Region (Republic of Congo). I. General aspects and functional studies. J. clin. Endocr., 21, 175-188.

Dewhurst, K. E., El Kabir, D. J., Exley, D., Harris, G. W., and Mandelbrote, B. M. (1968). Blood-levels of thyrotrophic hormone, protein-bound iodine, and cortisol in schizophrenia and affective states. Lancet, 2, 1160-1162.

Dodge, J. A., Neill, D. W., and Scally, B. G. (1967). Low butanolextractable-iodine levels in the serum of patients with Down's syndrome. Lancet, 1, 78-80.

Dolecek, R., and Klabusay, L. (1963). Laboratory and case history data of 500 obese patients: results of treatment. (Russian.) Klin. Med. (Mosk.), 41 (6), 28-34.

Doniach, D., Roitt, I. M., and Taylor, K. B. (1963). Autoimmune phenomena in pernicious anaemia. Brit. med. J., 1, 1374-1379.

Doniach, I., and Fraser, R. (1950). Effect of resorcinol on the thyroid uptake of $\mathrm{I}^{131}$ in rats. Lancet, $1,855-856$

Dowling, J. T., Freinkel, N., and Ingbar, S. H. (1956a). Thyroxinebinding by sera of pregnant women, new-born infants, and women with spontaneous abortion. J. clin. Invest., 35, 12631276.

Dowling, J. T., Freinkel, N., and Ingbar, S. H. (1956b). Effect of diethylstilbestrol on the binding of thyroxine in serum. $J$ clin. Endocr., 16, 1491-1506.

Dowling, J. T., Freinkel, N., and Ingbar, S. H. (1960a). The effect of estrogens upon the peripheral metabolism of thyroxine. J. clin. Invest., 39, 1119-1130.

Dowling, J. T., Ingbar, S. H., and Freinkel, N. (1960b). Iodine metabolism in hydatidiform mole and choriocarcinoma. J. clin. Endocr., 20, 1-12.

Dowling, J. T., Ingbar, S. H., and Freinkel, N. (1961). Abnormal jodoproteins in the blood of eumetabolic goitrous adults. J. clin. Endocr., 21, 1390-1401.

Dunn, J. T., and Stanbury, J. B. (1958). The metabolism of $3: 3^{\prime}: 5^{\prime}$ triiodothyronine in man. J. clin. Endocr., 18, 713-720.

DuRuisseau, J. P. (1965). Seasonal variation of PBI in healthy Montrealers. J. clin. Endocr., 25, 1513-1515.

Ekins, R. P., Williams, E. S., and Ellis, S. (1969). The sensitive and precise measurement of serum thyroxine by saturation analysis. Clin. Biochem., 2, 253-288.

El-Gholmy, A., Ghaleb, H., Khalifa, A. S., Senna, A., and El-Akkad, S. (1967). Studies on thyroid function in malnourished infants and children in Egypt. J. trop. Med. Hyg., 70, 74-80.

Emerick, R. W., Holly, L. E., Joistad, A. H., Jr., and Corrigan, K. E. (1954). Diagnostic use of radioisotopes in a general hospital. J. Amer. med. Ass., 154, 493-495.

Engbring, N. H., and Engstrom, W. W. (1959). Effects of estrogen and testosterone on circulating thyroid hormone. J. clin. Endocr. 19, 783-796.

Engel, A. G. (1961). Thyroid function and periodic paralysis. Amer. J. Med., 30, 327-333.

Engstrom, W. W., and Markardt, B. (1955). The effects of serious illness and surgical stress on the circulating thyroid hormone. J. clin. Endocr., 15, 953-963.

Engstrom, W. W., Markardt, B., and Liebman, A. (1952). Effect of estrogens on serum precipitable iodine. Proc. Soc. exp. Biol. (N.Y.), 81, 582-584.

Escobar del Rey, F., and Morreale del Escobar, G. (1962). The effect of butyl-4-hydroxy-3:5-diiodobenzoate on the availability of thyroid hormones to peripheral tissues in isotopically equilibrated rats. Acta endocr. (Kbh.), 40, 1-15. 
Farran, H. E. A., Lea, A. J., Goolden, A. W. G., and Abbatt, J. D. (1959). Iodinated tyrosines in the plasma of patients with thyrotoxicosis. Lancet, 1, 793-795.

Farrell, L. P., and Richmond, M. H. (1961). A rapid method for the estimation of serum protein-bound iodine. Clin. chim. Acta, 6 , 620-623.

Favino, A., Emrich, D., and Mühlen, A. von zur (1967). Separation and quantitative determination of ${ }^{131} \mathrm{I}$-triiodothyronine and ${ }^{131}$ I-thyroxine in human plasma by thin layer chromatography. Acta endocr. (Kbh.), 54, 362-374.

Federman, D. D., Robbins, J., and Rall, J. E. (1958). Effects of methyl testosterone on thyroid function, thyroxine metabolism, and thyroxine-binding protein. J. clin. Invest., 37, 1024-1030.

Feldman, J. D., and Danowski, T. S. (1956). Effect of estrogen on the metabolism of protein-bound iodine. Endocrinology, 59, 463471 .

Fisher, A. B., Levy, R. P., and Price, W. (1965). Gold-an occult cause of low serum protein-bound iodine. New Engl. J. Med., 273, 812-813.

Fisher, D. A. (1968). Artifactual deiodination during cellulose-starch thin layer chromatography. J. clin. Endocr., 28, 717-720.

Fisher, D. A., and Oddie, T. H. (1964). Neonatal thyroidal hyperactivity. Response to cooling. Amer. J. Dis. Child., 107, 574581.

Fisher, D. A., Oddie, T. H., and Burroughs, J. C. (1962). Thyroidal radioiodine uptake rate measurement in infants. Amer. J. Dis. Child., 103, 738-749.

Fisher, D. A., Oddie, T. H., and Epperson, D. (1965). Effect of increased dietary iodide on thyroid accumulation and secretion in euthyroid Arkansas subjects. J. clin. Endocr., 25, 1580-1590.

Fisher, D. A., Oddie, T. H., and Epperson, D. (1966). Norethynodrelmestranol and thyroid function. J. clin. Endocr., 26, 878-884.

Fisher, D. A., Oddie, T. H., and Wait, J. C. (1964). Thyroid function tests. Findings in Arkansas children and young adults. Amer. J. Dis. Child., 107, 282-287.

Florsheim, W. H., and Velcoff, S. M. (1962). Some effects of 2,4dichlorophenoxyacetic acid on thyroid function in the rat: effects on iodine accumulation. Endocrinology, 71, 1-6.

Földes, J., Gyertyánfy, G., Tamás, G., Gesztesi, E., and Takács, I. (1967). Der Plasma-Jodtyrosingehalt bei Euthyreose und Basedowscher Krankheit. Nucl.-Med. (Stuttg.), 6, 400-410.

Fore, W., Kohler, P., and Wynn, J. (1966). Rapid redistribution of serum thyroxine during ether anesthesia. J. clin. Endocr., 26, 821-830.

Freund, G., Thomas, W. C., Jr., Bird, E. D., Kinman, R. N., and Black, A. P. (1966). Effect of iodinated water supplies on thyroid function. J. clin. Endocr., 26, 619-624.

Freychet, P., Rosselin, G., Assan, R., Tchobroutsky, G., Dolais, J., and Dérot, M. (1967). Un cas de diabète sucré associé à une dysgénésie gonadique. Etude radioimmunologique plasmatique des hormones somatotrope, folliculo-stimulante et thyréotrope Presse méd., 75, 2381-2385.

Friis, T., and Secher, E. (1955). Protein-bound iodine of serum in induced abortion and at delivery. Acta endocr. (Kbh.), 18, 428436.

Furth, E. D., Rives, K., and Becker, D. V. (1966). Nonthyroidal action of propylthiouracil in euthyroid, hypothyroid and hyperthyroid man. $J$. clin. Endocr., 26, 239-246.

Gabrilove, J. L., Alvarez, A. A., and Soffer, L. J. (1958). Effect of acetazoleamide (Diamox) on thyroid function. J. appl. Physiol. 13, 491-492.

Gaelen, L. H., and Levitan, S. (1968). Myasthenia gravis and thyroid function. Arch. Neurol. (Chic.), 18, 107-110.

Gaffney, G. W., Gregerman, R. I., Yiengst, M. J., and Shock, N. W. (1960). Serum protein-bound iodine concentration in blood of euthyroid men aged 18 to 94 years. J. Geront., 15, 234-241.

Galletti, P. M., and Joyet, G. (1958). Effect of fluorine on thyroidal iodine metabolism in hyperthyroidism. J. clin. Endocr., 18, $1102-1110$

Garcia, J., Harris, G. W., and Schindler, W. J. (1964). Vasopressin and thyroid function in the rabbit. J. Physiol. (Lond.), 170, 487 515.

Gibbons, J. L., Gibson, J. G., Maxwell, A. E., and Willcox, D. R. C. (1960). An endocrine study of depressive illness. J. psychosom. Res., 5, 32-41.

Gimlette, T. M. D. (1960). Thyroid acropachy. Lancet, 1, 22-24.

Gjessing, L. R. (1964). Studies of periodic catatonia. I. Blood levels of protein-bound iodine and urinary excretion of vanillylmandelic acid in relation to clinical course. J. psychiat. Res., 2, 123-134.
Goldberg, M., and Gordon, E. S. (1964). Energy metabolism in human obesity. Plasma free fatty acid, glucose and glycerol response to epinephrine. J. Amer. med. Ass., 189, 616-623.

Goldsmith, R. E., Rauh, J. L., Kloth, R., and Dahlgren, J. (1967). Observations on the relationship between the maximal thyroxine binding capacities of thyroxine-binding interalpha globulin and thyroxine-binding prealbumin, the serum protein bound iodine concentration and sexual maturity in adolescents. Acta endocr. (Kbh.), 54, 494-504.

Goldstein, J. E. (1964). Paresis of superior rectus muscle associated with thyroid dysfunction. Arch. Ophthal., 72, 5-8.

Good, B. F., Potter, H. A., and Hetzel, B. S. (1965). The effect of salicylate and related drugs on thyroxine binding in man. Aust. J. exp. Biol. med. Sci., 43, 291-304.

Goodwin, J. F., Miller, H., and Wayne, E. J. (1949). A comparison of the anti-thyroid activity of para-aminobenzoic acid and thiouracil compounds. Lancet, 2, 1211-1213.

Goolden, A. W. G., Gartside, J. M., and Sanderson, C. (1967) Thyroid status in pregnancy and in women taking oral contraceptives. Lancet, 1, 12-15.

Gosling, P. H. (1968). Thyroid and adrenocortical function in psychiatric illness. Lancet, 2, 1346-1347.

Gottschalk, C. W., and Riggs, D. S. (1952). Protein-bound iodine in the serum of soldiers and of Eskimos in the Arctic. J. clin. Endocr., 12, 235-243.

Grayson, R. R. (1960). Factors which influence the radioactive iodine thyroidal uptake test. Amer. J. Med., 28, 397-415.

Greenberg, H. B. (1966). Low radioiodine uptake and high serum PB levels from hemorrhage into thyroid adenoma. J. nucl. Med.. 7, 787-791.

Gregerman, R. I., and Solomon, N. (1967). Acceleration of thyroxine and triiodothyronine turnover during bacterial pulmonary infections and fever: implications for the functional state of the thyroid during stress and in senescence. J. clin. Endocr., 27, 93-105.

Greggia, A., Maggi, G. C., Mucci, P., Patrignani, A., and Sternieri, E. (1968). Thyroid inhibition by $\gamma$-amino- $\beta$-hydroxybutyric acid. Biochem. Pharmacol., 17, 1120-1123.

Greig, W. R., Smith, J. F. B., Gillespie, F. C., Thomson, J. A., and McGirr, E. M. (1969). Iodine-125 treatment for thyrotoxicosis. Lancet, 1, 755-757.

Gribetz, D., Talbot, N. B., and Crawford, J. D. (1954). Goiter due to lymphocytic thyroiditis (Hashimoto's struma). Its occurrence in preadolescent and adolescent girls. New Engl. J. Med., 250, 555-557.

Grob, D. (1958). Myasthenia gravis. Current state of pathogenesis clinical manifestations and management. J. chron. Dis., 8, 536-566.

Hallman, B. L., Bondy, P. K., and Hagewood, M. A. (1951). Determination of serum protein-bound iodine as a routine clinical procedure. Arch. intern. Med., 87, 817-824.

Hamwi, G. J., Skillman, T. G., and Tufts, K. C., Jr. (1960). Acromegaly. Amer. J. Med., 29, 690-699.

Hansen, H. H. (1966). Sephadex binding of ${ }^{131}$ I-labelled L-triiodothyronine as a test of thyroid function. Scand. J. clin. Lab. Invest., 18, 240-244.

Hansen, J. M., and Siersboeck-Nielsen, K. (1967). Serum proteinbound iodine and serum thyroxine during perphenazine therapy. Acta endocr. (Kbh.), 55, 136-145.

Harden, R. McG., Chisholm, C. J. S., and Cant, J. S. (1967). The effect of metronidazole on thyroid function and exophthalmos in man. Metabolism, 16, 890-898.

Hardy, H. L., Jeffries, W. McK., Wasserman, M. M., and Waddell, W. R. (1950). Thiocyanate effect following industrial cyanide exposure. Report of two cases. New Engl. J. Med., 242, 968972.

Harland, W. A., and Orr, J. S. (1969). The role of thyroxine binding in the establishment of thyroid status. Scot. med. J., 14, 375380 .

Harper, R. G., Orti, E., and Baker, R. K. (1967). Bird-headed dwarfs (Seckel's symdrome). A familial pattern of developmental, dental, skeletal, genital and central nervous system anomalies. J. Pediat., 70, 799-804.

Harrison, M. T., and Cameron, A. J. V. (1965). Iodine-induced hypothyroidism due to benziodarone (Cardivix). Brit. med. J., 1, 840.

Harrison, M. T., and Harden, R. McG. (1966). Some effects of clofibrate in hypothyroidism and on the metabolism of thyroxine Scot. med. J., 11, 213-217. 
Harrison, M. T., Harden, R. McG., and Alexander, W. D. (1967). Effect of calcium on iodine metabolism in man. Metabolism, 16, 84-86.

Hart, I. R., and McKendry, J. B. R. (1967). Serum protein-bound iodine levels in adolescents. Canad. med. Ass. J., 97, 516-521.

Hayles, A. B., Hinrichs, W. L., and Tauxe, W. N. (1965). Thyroid disease among children with Down's syndrome (mongolism). Pediatrics, 36, 608-614.

Heijdemann, S. F. B., and Lindeboom, G. A. (1958). Artificially elevated protein-bound-iodine values in the blood. Clin. chim. Acta, 3, 565-570.

Heinemann, M., Johnson, C. E., and Man, E. B. (1948). Serum precipitable iodine concentrations during pregnancy. J. clin. Invest., 27, 91-97.

Hendrizk, J. W. (1956). Diagnosis and treatment of thyroiditis. Ann. Surg., 144, 176-187.

Henry, R. J. (1964). Clinical Chemistry, Hoeber, New York.

Hershman, J. M. (1964). Effect of 5- and 6-propylthiouracil on the metabolism of L-thyroxine in man. J. clin. Endocr., 24, 173-179.

Hill, S. R., Jr., Reiss, R. S., Forsham, P. H., and Thorn, G. W. (1950). The effest of adrenocorticotropin and cortisone on thyroid function: thyroid-adrenocortical interrelationships. $J$. clin. Endocr., 10, 1375-1400.

Hillman, J. C., Hammond, J., Noé, O., and Reiss, M. (1968), Endocrine investigations in de Lange's and Seckel's syndromes. Amer. J. ment. Defic., 73, 30-33.

Hintze, G., Fortelius, P., and Railo, J. (1964). Epidemic thyroiditis. Acta endocr. (Kbh.), 45, 381-401.

Hippe, E. (1967). Hereditary ectodermal dysplasia of anhidrotic type with increased protein-bound serum thyroxine. Acta paediat. (Uppsala), 56, 687-692.

Hiss, J. M., Jr., and Dowling, J. T. (1962). Thyroxine metabolism in untreated and treated pancreatic steatorrhea. J. clin. Invest., 41, 988-995.

Hozman, G. (1966). The use of Sephadex in the chromatography of thyroxine-containing compounds: a critique. J. Chromat., 21, 413-418.

Holland, C. M., Jr., and Hill, S. R., Jr. (1956). Myotonia dystrophica: report of six cases in one family, with an analysis of the metabolic defects. Ann. intern. Med., 44, 738-753.

Hollander, C. S., Bernstein, G., and Oppenheimer, J. H. (1968). Abnormalities of thyroxine binding in analbuminemia. J. clin. Endocr., 28, 1064-1066.

Hollander, C. S., Garcia, A. M., Sturgis, S. H., and Selenkow, H. A. (1963). Effect of an ovulatory suppressant on the serum proteinbound iodine and the red-cell uptake of radioactive tri-iodothyronine. New Engl. J. Med., 269, 501-504.

Hollander, C. S., Scott, R. L., Burgess, J. A., Rabinowitz, D., Merimee, T. J., and Oppenheimer, J. H. (1967a). Free fatty acids: a possible regulator of free thyroid hormone levels in man. J. clin. Endocr., 27, 1219-1223.

Hollander, C. S., Scott, R. L., Tschudy, D. P., Perlroth, M., Waxman, A., and Sterling, K. (1967b). Increased protein-bound iodine and thyroxine-binding globulin in acute intermittent porphyria. New Engl. J. Med., 277, 995-1000.

Hollander, D., Meek, J. C., and Manning, R. T. (1967c). Determination of free thyroxine in serum of patients with cirrhosis of the liver. New Engl. J. Med., 276, 900-902.

Hoppe, G., Zappi, E., and Gries, G. (1967). Ein neues kombiniertes Verfahren zur Analyse von Schilddrüsen-Hormonen und deren Metaboliten im Serum. Nucl.-Med. (Stuttg.), 6, 44-52.

Horst, W., Rösler, H., Schneider, C., and Labhart, A. (1967). 306 cases of toxic adenoma: clinical aspects, findings in radioiodine diagnostics, radiochromatography and histology; results of ${ }^{131}$ I and surgical treatment. J. nucl. Med., 8, 515-528.

Hortling, H., Chapelle, A. de la, Frisk, M., and Widholm, O. (1964). The syndromes of obesity and of delayed growth in adolescence. Acta med. scand., 175, Suppl., 412, 109-122.

Howorth, P. J. N., and Maclagan, N. F. (1969). Clinical application of serum-total-thyroxine estimation, resin uptake and freethyroxine index. Lancet, 1, 224-228.

Hubble, D. (1963). Precocious menstruation in a mongoloid child with hypothyroidism-hormonal overlap. J. clin. Endocr., 23, 1302-1305.

Huffer, V., Scott, W. H., Connor, T. B., and Lovice, H. (1964). Psychological studies of adult male patients with sexual infantilism before and after androgen therapy. Ann. intern. Med., 61, 255-268.
Hunton, R. B., Wells, M. V., and Skipper, E. W. (1965). Hypothyroidism in diabetics treated with sulphonylurea. Lancet, 2, 449451.

Hydovitz, J. D., and Rose, E. (1956). Goiter and myxedema following prolonged ingestion of iodine: report of a case with evidence of unusual thyroid dysfunction. J. clin. Endocr., 16, 1109-1116.

Inada, M., and Sterling, K. (1967a). Thyroxine turnover and transport in active acromegaly, $J$, clin. Endocr., 27, 1019-1027.

Inada, M., and Sterling, K. (1967b). Thyroxine turnover and transport in Laennec's cirrhosis of the liver. J. clin. Invest., 46, 1275-1282.

Ingbar, S. H. (1960). The interaction of the thyroid hormones with the proteins of human plasma. Ann. N.Y. Acad. Sci., 86, 440453.

Ingbar, S. H. (1961a). Clinical and physiological observations in a patient with an idiopathic decrease in the thyroxine-binding globulin of plasma. J. clin. Invest., 40, 2053-2063.

Ingbar, S. H. (1961 b). The action of 1,1,3-tricyano-2-amino-1-propene (U-9189) on the thyroid gland of the rat and its effects in human thyrotoxicosis. J. clin. Endocr., 21, 128-139.

Ingbar, S. H., and Bass, D. E. (1957). The effect of prolonged exposure to cold on production and degradation of thyroid hormone in man. (Abstr.) J. Endocr., 15, ii-iii.

Ingbar, S. H., Braverman, L. E., Dawber, N. A., and Lee, G. Y. (1965). A new method for measuring the free thyroid hormone in human serum and an analysis of the factors that influence its concentration. J. clin. Invest., 44, 1679-1689.

Ingbar, S. H., and Freinkel, N. (1956). ACTH, Cortisone and the metabolism of iodine. Metabolism, 5, 652-666.

Ingbar, S. H., and Freinkel, N. (1958). Thyroid function and the metabolism of iodine in patients with subacute thyroiditis. Arch, intern. Med., 101, 339-346.

Irvine, C. H. G. (1968). Effect of exercise on thyroxine degradation in athletes and non-athletes. J. clin. Endocr., 28, 942-948.

Irvine, W. J., Davies, S. H., Delamore, I. W., and Wynn-Williams, A. (1962). Immunological relationship between pernicious anaemia and thyroid disease. Brit. med. J., 2, 454-456.

Irvine, W. J., and Standeven, R. M. (1967). Serum tri-iodothyronine uptake using coated charcoal in the assessment of thyroid function. J. Endocr., 41, 31-40.

Jaakonmäki, P. I., and Stouffer, J. E. (1967). Gas chromatographic analysis with electron capture detection of thyroid hormones. J. Gas Chromat., 5, 303-306.

Jacobson, W. E., Schultz, A. L., and Anderson, J. (1955). Endocrine studies in 8 patients with dystrophia myotonica. J. clin. Endocr., 15, 801-810.

Jagiello, G. M., Kaminetsky, H. A., Ricks, P., Jr., and Ryan, R. J. (1966). Primary amenorrhea. A cytogenetic and endocrinologic study of 18 cases. J. Amer. med. Ass., 198, 30-38.

Janotka, M., Ondrejička, M., and Pechán, J. (1967). The radio-iodine ${ }^{131} I$ conversion ratio and protein-bound iodine in atherosclerosis. J. Atheroscler. Res., 7, 771-776.

Jones, J. E., and Seal, U. S. (1967). X-chromosome linked inheritance of elevated thyroxine-binding globulin. J. clin. Endocr., 27, 1521-1528.

Kahn, A., Cogan, S. R., and Berger, S. (1962). Circulating iodoprotein in two patients with autonomous thyroid nodules. J. clin. Endocr., 22, 1-7.

Katz, J. F. (1955). Protein-bound iodine in Legg-Calvé-Perthes disease. J. Bone Jt Surg., 37A, 842-846.

Keitel, H. G., and Sherer, M. G. (1957). Marked depression of the plasma protein-bound iodine concentration in the absence of clinical hypothyroidism during testosterone medication. J. clin. Endocr., 17, 854-861.

Kilpatrick, R., and Wilson, G. M. (1964). Simple non-toxic goitre. In The Thyroid Gland, edited by $\mathbf{R}$. Pitt-Rivers and W. R. Trotter, vol. 2, pp. 88-111. Butterworth, London.

Kinsella, R. A., and Back, D. K. (1968). Thyroid acropachy. Med Clin. N. Amer., 52, 393-398.

Klassen, K. P., Riley, E. L., and Curtis, G. M. (1945). The blood iodine in pulmonary tuberculosis. Amer. Rev. Tuberc., 51, 561-565.

Klevit, H. D., Eberlein, W. R., and Bongiovanni, A. M. (1965). The iodoproteins in the iodotyrosyl coupling defect.J. clin. Endocr., 25, 585-592.

Kondritzer, A. A., Zvirblis, P., Goodman, A., and Paplanus, S. H (1968). Blood plasma levels and elimination of salts of 2-PAM in man after oral administration. J. pharm. Sci., 57, 1142-1146.

Korst, D. R., and Beierwaltes, W. H. (1956). Epinephrine induced rise in basal metabolic rate and fall in serum protein-bound iodine in man. Trans. Amer. Goiter Ass., 178-185. 
Kozac, G. P., Vagnucci, A. I., Lauler, D. P., and Thorn, G. W. (1966). Acromegaly pre- and post-pituitary irradiation. Metabolism, 15, 290-303.

Kraemer, E., and Wiswell, J. G. (1968). Familial thyroxine-binding globulin deficiency. Metabolism, 17, 260-262.

Krikler, D. M. (1966). Adrenergic receptor blockade. Lancet, 1, 268.

Kydd, D. M., and Man, E. B. (1951). Precipitable iodine of serum (SPI) in disorders of the liver. $J$. clin. Invest., 30, 874-878.

Kydd, D. M., Man, E. B., and Peters, J. P. (1950). Concentration of precipitable iodine in the serum. J. clin. Invest., 29, 1033-1040.

Landwirth, J., Schwartz, A. H., and Grunt, J. A. (1968). Prader-Willi syndrome. Amer. J. Dis. Child., 116, 211-217.

Lavietes, P. H., and Epstein, F. H. (1964). Thyroid therapy of myxedema. A comparison of various agents with a note on the composition of thyroid secretion in man. Ann. intern. Med., $60,79-87$.

Lederer, J., and Bataille, J. P. (1969). Sénescence et fonction thyroïdienne. Ann. Endocr. (Paris), 30, 598-603.

Leeper, R. D., Benua, R. S., Brener, J. L., and Rawson, R. W. (1960). Hyperuricemia in myxedema. J. clin. Endocr., 20, 1457-1466.

Leistyna, J. A., Hassan, A. H. I., Aplin, E., and Green, O. C. (1964). Thyroid function in phenylketonuria. Ohio St. med. J., 60 , 949-953.

Lemarchand-Béraud, T., Assayah, M.-R., and Vannotti, A. (1964). Alterations of thyroxine-binding protein in clinically hypoand hyperthyroid patients with normal PBI level. Acta endocr. (Kbh.), 45, 99-113.

Leone, N. C., Leatherwood, E. C., Petrie, I. M., and Lieberman, L. (1964). Effect of fluoride on thyroid gland: clinical study. J. Amer. dent. Ass., 69, 179-180.

Levi, L. (1967). Das Experiment am Menschen in der Psychosomatik. Verh. dtsch. Ges. inn. Med., 73, 58-70.

Levy, R. P., and Marshall, J. S. (1964). Short-term drug effects on thyroid function tests. Arch. intern. Med., 114, 413-416.

Lewitus, Z., and Steinitz, K. (1963). The effect of venous occlusion on determination of protein-bound iodine. Clin. chim. Acta, 8, 629-631.

Libow, L. S., and Durell, J. (1965). Clinical studies on the relationship between psychosis and the regulation of thyroid gland activity. I. Periodic psychosis with coupled change in thyroid function. Report of a case. Psychosom. Med., 27, 369-376.

Liddle, G. W., Heyssel, R. M., and McKenzie, J. M. (1965). Graves' disease without hyperthyroidism. Amer. J. Med., 39, 845-848.

Liechty, R. D., Hodges, R. E., and Burket, J. (1963). Cancer and thyroid function. J. Amer. med. Ass., 183, 30-32.

Liewendahl, K., and Lamberg, B. A. (1969). Free thyroxine in serum and its use in clinical diagnosis. Acta endocr. (Kbh.), 61, 343358.

Lightfoot, R. W., Jr., and Christian, C. L. (1966). Serum protein binding of thyroxine and diphenylhydantoin. J. clin. Endocr., 26, 305-308.

Lindsay, S. (1960). Carcinoma of the Thyroid Gland. Thomas, Springfield, Ill.

Lindsten, J., Bergstrand, C. G., Tillinger, K.-G., Schwarzacher, H. G., Tiepolo, L., Muldal, S., and Hökfelt, B. (1966). A clinical and cytogenetical study of three patients with male phenotype and apparent XX sex chromosome constitution. Acta endocr. $(K b h), 52,.91-112$.

Linsk, J. A., Paton, B. C., Persky, M., Isaacs, M., and Kupperman, H. S. (1957). The effect of phenylbutazone and a related analogue (G25671) upon thyroid function. J. clin. Endocr., 17, 416-423.

Lissitzky, S., Codaccioni, J. L., Bismuth, J., and Depieds, R. (1967). Congenital goiter with hypothyroidism and iodo-serum albumin replacing thyroglobulin. J. clin. Endocr., 27, 185-196.

Lissitzky, S., Codaccioni, J. L., Cartouzou, G., and Mante, S. (1964). Eumetabolic goitrous adult with iodoprealbumin in thyroid tissue and blood. J. clin. Endocr., 24, 305-312.

Lizarralde, G., Jones, B., Seal, U. S., and Jones, J. E. (1966). Goitrous cretinism with chromosomal aberration and defect in thyroglobulin synthesis. J. clin. Endocr., 26, 1227-1231.

Lloyd, K. E., Kaplan, L. I., Kupperman, H. S., Grynbaum, B. B., and Rusk, H. A. (1964). A follow-up study of patients with spinal cord dysfunction: endocrine and metabolic findings. Arch. phys. Med., 45, 184-192.

Logan, J. (1957). Thyroidal depression following high doses of vitamin A. N.Z. med. J., 56, 249.

Lomonaco, D. A., Oliveira, H. L., Kieffer, J., and Pieroni, R. R. (1966). Abnormal regulation of thyroid function in patients with chronic Chagas' disease. Acta endocr. (Kbh.), 53, 162-176.
London, R., Drukker, A., and Sandbank, U. (1965). Fanconi's ڤ్ర anaemia with hydrocephalus and thyroid abnormality. Arch. Dis. Childh., 40, 89-92.

Lowrey, R., and Starr, P. (1959). Chemical evidence of incidence of hypothyroidism. J. Amer. med. Ass., 171, 2045-2048.

Lubowe, I. I. (1963). Laboratory studies in male pattern type and diffuse female type in alopecia. Med. Tms (N.Y.), 91, 383-384.

Lucis, O. J., Cummings, G. T., Matthews, S., and Burry, C. (1969). Laboratory observations of assays of serum thyroxine and protein-bound iodine. J. nucl. Med., 10, 160-163.

Lüllmann, H. (1962). Die Nebenwirkungen von Phenylbutazon. Dtsch. med. Wschr., 87, 30-34.

Lundberg, P. O. (1966). Observations on endocrine function in ocular myopathy. Acta neurol. scand., 42, 39-61.

McConahey, W. M., Keating, F. R., Jr., Butt, H. R., and Owen, C. A., $\vec{\odot}$ Jr. (1961). Comparison of certain laboratory tests in the $\rightarrow$ diagnosis of Hashimoto's thyroiditis. J. clin. Endocr., 21, 879886.

Macgregor, A. G., and Somner, A. R. (1954). The anti-thyroid action of para-aminosalicylic acid. Lancet, 2, 931-936.

Maclagan, N. F., and Howorth, P. J. N. (1969). Thyroid function is studies using resin uptake of radioactive thyronines from $\triangle$ serum and total thyroxine assay; the free thyroxine index. $\omega$ Clin. Sci., 37, 45-60.

Mack, R. E., Hart, K. T., Druet, D., and Bauer, M. A. (1961). An $\infty$ abnormality of thyroid hormone secretion. Amer. J. Med., 30, 323-326.

Magnin, P., Bigot, P., Nuon-Hoa, and Moine, C. (1968). Note sur l'iode protidique sanguin dans les menaces d'avortement. Presse méd., 76, 109-110.

Major, P. W., and Munro, D. S. (1962). Observations on the stimulation of thyroid function in mice by the injection of serum from normal subjects and from patients with thyroid disorders. Clin. Sci., 23, 463-475.

Man, E. B., Kydd, D. M., and Peters, J. P. (1951). Butanol-extractable iodine of serum. J. clin. Invest., 30, 531-538.

Man, E. B., Reid, W. A., and Jones, W. S. (1968). Thyroid function in human pregnancy. IV. Serum butanol-extractable iodine drop with weight gain. Amer. J. Obstet. Gynec., 102, 244-247.

Manfredi, P. (1964). Sulla sindrome ipertiroidea nell' età climaterica. Rass. int. Clin. Ter., 44, 586-592.

Marczynska, A., Kołodziejska, H., Glińska, H., and Adamczyk, B. (ृ) (1965). The evaluation of thyroid function in woman with advanced breast cancer. Radiobiol. Radiother. (Berl.), 6, 207- $\overline{\bar{O}}$ 210.

Margolese, M. S., and Golub, O. J. (1957). Daily fluctuation of the serum protein-bound iodine level. J. clin. Endocr., 17, 849-853.

Marks, J. F, and Hamlin, M. (1967). Free thyroxine levels in children with mongolism. J. Pediat., 70, 435-436.

Marmorston, J., Hoffman, O., Sobel, H., and Starr, P. (1955). Urinary $\overparen{\Omega}$ estrogen and serum protein-bound iodine levels in a group of post-menopausal women with and without myocardial infarction. Minn. Med., 38, 800, 808 .

Marshall, J. S., and Tompkins, L. S. (1968). Effect of o,p'-DDD and similar compounds on thyroxine binding globulin. J. clin. Endocr., 28, 386-392.

Matovinović, J., and Ramalingaswami, V. (1960). Therapy and 0 prophylaxis of endemic goitre. Wld Hlth Org. Monogr. Ser., $44,385-410$.

McGowan, G. K., and Sandler, M., eds. (1967). Symposium on the thyroid gland. J. clin. Path., 20, (Suppl. 1), 309-413.

Means, J. H., De Groot, L. J., and Stanbury, J. B. (1963). The Thyroid $N$ and its Diseases, 3rd ed. McGraw-Hill, New York.

Mehbod, H., Swartz, C. D., and Brest, A. N. (1967). The effect of $\mathrm{N}$ prolonged thiazide administration on thyroid function. Arch. N intern. Med., 119, 283-286.

Mess, B., and Szántó, L. (1964). Experimental hyperthyroidism $\sigma$ induced by chronic lysergic acid butanolamide treatment. Acta physiol. Acad. Sci. hung., 25, 83-88.

Michell, J. (1966). Automated serum iodine-an assessment. Proc. Ass. clin. Biochem., 4, 77.

Milne, K., and Greer, M. A. (1962). Comparison of the effects of propylthiouracil and sulfadiazine on thyroidal biosynthesis and the manner in which they are influenced by supplemental iodine. Endocrinology, 71, 580-587.

Mitchell, M. L., Harden, A. B., and O'Rourke, M. E. (1960). The in vitro resin sponge uptake of triiodothyronine- $I^{131}$ from 0 serum in thyroid disease and in pregnancy. J. clin. Endocr., 20, 1474-1483. 
Miyai, K., Itoh, K. F., Abe, H., and Kumahara, Y. (1968). Radioimmunoelectrophoretic analysis of thyroxine-binding proteins in normal human sera. Clin. chim. Acta, 22, 341-347.

Morreale de Escobar, G., and Escobar del Rey, F. (1961a). The effect of 2,4-dinitrophenol on the tissue concentration of iodinecontaining compounds in isotopically equilibrated intact rats. J. Physiol. (Lond.), 159, 1-14.

Morreale de Escobar, G., and Escobar del Rey, F. (1961b). The effect of 2,4-dinitrophenol on the 'uptake' of labelled thyroid hormones by red blood cells and rat diaphragms. J. Physiol. (Lond.), 159, 15-25.

Mueller, R., Brausch, C. C., Hirsch, E. Z., Benua, R. S., and Dobyns, B. M. (1954). Uptake of radioactive iodine in the thyroid of patients with impaired liver function. J. clin. Endocr., 14, 1287 1299.

Munkner, T. (1965). The influence of para-aminosalicylic acid on the $I^{131}$ metabolism. Acta radiol. Diagn., Suppl., 234.

Murdoch, J. McC., and Campbell, G. D. (1958). Antithyroid activity of N-phthalyl glutamic acid imide (K 17). Brit. med. J., 1, 84-85.

Murphy, B. E. P. (1969). Protein binding and the assay of nonantigenic hormones. Recent Progr. Hormone Res., 25, 563-610.

Murphy, B. E. P., Pattee, C. J., and Gold, A. (1966). Clinical evaluation of a new method for the determination of serum thyroxine. J. clin. Endocr., 26, 247-256.

Murray, I. P. C., and McGirr, E. M. (1964). Iodine metabolism in thyroid dysfunction. In The Thyroid Gland, edited by R. PittRivers and W. R. Trotter, vol. 2, pp. 39-70. Butterworth, London.

Myant, N. B., and Pochin, E. E. (1950). The metabolism of radiothyroxine in man. Clin. Sci., 9, 421-440.

Meyers, J. H., and Man, E. B. (1951). Artifactual values of serum precipitable iodine after clinical intramuscular injections of mercuhydrin. J. Lab. clin. Med., 37, 867-869.

Myhill, J., Reeve, T. S., and Hales, I. B. (1966). Thyroid function in breast cancer. Acta endocr. (Kbh.), 51, 290-300.

Nauman, J. A., Nauman, A., and Werner, S. C. (1967). Total and free triiodothyronine in human serum. J. clin. Invest., 46, 1346-1355.

Neel, J. V., Mikkelsen, W. M., Rucknagel, D. L., Weinstein, E. D., Goyer, R. A., and Abadie, S. H. (1968). Further studies of the Xavante Indians. VIII. Some observations on blood, urine, and stool specimens. Amer. J. trop. Med. Hyg., 17, 474-485.

Nikolai, T. F., and Seal, U. S. (1967). X-chromosome linked inheritance of thyroxine-binding globulin deficiency. J. clin. Endocr. 27, 1515-1520.

Nikula-Baumann, L., Hiisi-Brummer, L., and Baumann, J. (1965). Über endokrine Befunde bei Involutionsdepressionen. Acta psychiat. scand., 40, Suppl., 180, 199-205.

Notter, G. (1962). Influence of ACTH on the accumulation of radioiodine in the human thyroid-a new extra-adrenocortical effect of ACTH. J. clin. Endocr., 22, 817-823.

Nunez, J., and Pommier, J. (1968). Iodation des protéines par voie enzymatique. 2. Formation d'un composé intermédiaire peroxydase-halogène. Europ. J. Biochem., 5, 114-118.

Odell, W. D. (1966). Isolated deficiencies of anterior pituitary hormones. Symptoms and diagnosis. J. Amer. med. Ass., 197, 1006-1016.

Odell, W. D., Bates, R. W., Rivlin, R. S., Lipsett, M. B., and Hertz, R. (1963). Increased thyroid function without clinical hyperthyroidism in patients with choriocarcinoma. J. clin. Endocr. 23, 658-664.

O'Halloran, M. W., and Wellby, M. L. (1966). Recoveries of iodine131-labelled iodo-aminoacids in the plasma protein-bound iodine assay. Nature (Lond.), 211, 1195-1197.

Oltman, J. E., and Friedman, S. (1963). Protein-bound iodine in patients receiving perphenazine. J. Amer. med. Ass., 185, 726-727.

Oppenheimer, J. H. (1968). Role of plasma proteins in the binding, distribution and metabolism of the thyroid hormones. New Engl. J. Med., 278, 1153-1162.

Oppenheimer, J. H., Bernstein, G., and Hasen, J. (1967). Estimation of rapidly exchangeable cellular thyroxine from the plasma disappearance curves of simultaneously administered thyroxine${ }^{131}$ I and albumin-125I. J. clin. Invest., 46, 762-777.

Oppenheimer, J. H., Squef, R., Surks, M. I., and Hauer, H. (1963). Binding of thyroxine by serum proteins evaluated by equilibrium dialysis and electrophoretic techniques. Alterations in non-thyroidal illness. J. clin. Invest., 42, 1769-1782.

Oppenheimer, J. H. Surks, M. I., and Schwartz, H. L. (1969). The metabolic significance of exchangeable cellular thyroxine. Recent Progr. Hormone Res., 25, 381-422.

Oppenheimer, J. H., and Tavernetti, R. R. (1962). Studies on the thyroxine-diphenylhydantoin interaction: effect of 5,5'diphenylhydantoin on the displacement of L-thyroxine from thyroxine-binding globulin (TBG). Endocrinology, 71, 496-504.

Oppenheimer, J. H., and Werner, S. C. (1966). Effect of prednisone on thyroxine-binding proteins. J. clin. Endocr., 26, 715-721.

Owen, C. A., Jr., and McConahey, W. M. (1956). An unusual iodinated protein of the serum in Hashimoto's thyroiditis. $J$. clin Endocr., 16, 1570-1579.

Owen, C. A., McConahey, W. M., Childs, D. S., Jr., and McKenzie, B. F. (1960). Serum 'thyroglobulin' in thyroidal carcinoma. J. clin. Endocr., 20, 187-204.

Paine, J. R., Terplan, K., Rose, N. R., Witebsky, E., and Egan, R. W. (1957). A clinical study of chronic noninfections thyroiditis and autoimmunization. Surgery, 42, 799-813.

Parhon-Stefănescu, K., Nikolau, G., Aurora, A., Kuku, I., and Vianu I. (1966). Iodine content in blood in depressive states. (Russian.) Zh. Nevropat. Psikhiat., 66, 588-590.

Parra Jiménez, N., Rodríguez García, P., Roche, M., and Gaede, K. (1962). Circulating iodothyronines in subjects from an endemic goiter area. J. clin. Endocr., 22, 754-756.

Pastan, I. (1966). Biochemistry of the nitrogen-containing hormones. Ann. Rev. Biochem., 35, 369-404.

Pearse, J. J., Reiss, M., and Suwalski, R. T. (1963). Thyroid function in patients with mongolism. J. clin. Endocr., 23, 311-312.

Perlmutter, M., and Mufson, M. (1951). Inhibition of a cervical thyroid gland by a functioning struma ovarii. J. clin. Endocr., 11, 621-629.

Perry, W. F., and Cosgrove, J. B. R. (1949). Protein-bound plasma iodine as an aid in the diagnosis of thyroid disease. Canad. med. Ass. J., 60, 602-606.

Perry, W. F., and Hughes, J. F. S. (1952). The urinary excretion and thyroid uptake of iodine in renal disease. J. clin. Invest., 31, 457-463.

Peter, R. H., Gracey, J. G., and Beach, T. B. (1968). A clinical profile of idiopathic atrial fibrillation. A functional disorder of atrial rhythm. Ann. intern. Med., 68, 1288-1295.

Peters, J. P., and Man, E. B. (1948). The relation of albumin to precipitable iodine of serum. J. clin. Invest., 27, 397-405.

Philp, J. R., Duthie, M. B., and Crooks, J. (1968). A follow-up scheme for detecting hypothyroidism in thyrotoxic patients treated with radioiodine, Lancet, $2,1336-1338$.

Pileggi, V. J., and Kessler, G. (1968). Determination of organic iodine compounds in serum. IV. A new nonincineration technic for serum thyroxine. Clin. Chem., 14, 339-347.

Pileggi, V. J., Segal, H. A., and Lanchantin, G. F. (1963). The effect of sulfobromophthalein on serum PBI, BEI, and thyroxineiodine. Clin. chim. Acta, 8, 547-551.

Pinchera, A., MacGillivray, M. H., Crawford, J. D., and Freeman, A. G. (1965a). Thyroid refractoriness in an athyreotic cretin fed soybean formula. New Engl. J. Med., 273, 83-87.

Pinchera, A., Pinchera, M. G., and Stanbury, J. B. (1965b). Thyrotropin and long-acting thyroid stimulator assays in thyroid disease. J. clin. Endocr., 25, 189-208.

Pitt-Rivers, R. (1967). The biosynthesis of thyroid hormones. J. clin. Path., 20, (Suppl. 1), 318-322.

Pittman, J. A. (1962). Antithyroid activity of a tranquilizer. New Engl. J. Med., 267, 861-864.

Plunkett, E. R., Rangecroft, G., and Heagy, F. C. (1964). Thyroid function in patients with sex chromosomal anomalies. J. ment. Defic. Res., 8, 25-34.

Radcliff, F. J., Baker, J. M., Croydon, M. J., Hart, M. J., and Hales, I. B. (1964). Diagnostic value of the estimation of proteinbound iodine in thyroid disease: survey of an Australian population group. J. clin. Endocr., 24, 883-886.

Rall, J. E., and Conard, R. A. (1966). Elevation of the serum proteinbound iodine level in inhabitants of the Marshall Islands. Amer. J. Med., 40, 883-886.

Rall, J. E., Robbins, J., and Lewallen, C. G. (1964). The thyroid. In The Hormones, edited by G. Pincus, K. V. Thimann, and E. B. Astwood, vol. 5, pp. 159-439. Academic Press, New York.

Rallison, M. L., Kumagai, L. F., and Tyler, F. H. (1967). Goitrous hypothyroidism induced by amino-glutethimide, anticonvulsant drug. J. clin. Endocr., 27, 265-272.

Ramalingaswami, V. (1964). Endemic goitre. In The Thyroid Gland, edited by R. Pitt-Rivers and W. R. Trotter, vol. 2, pp. 71-87. Butterworth, London. 
Rasmusson, H. (1956). Thyroxine metabolism in the nephrotic syndrome. J. clin. Invest., 35, 792-799.

Rawson, R. W., and Rall, J. E. (1955). The endocrinology of neoplastic disease. Recent Progr. Hormone Res., 11, 257-284.

Recant, L., and Riggs, D. S. (1952). Thyroid function in nephrosis. J. clin. Invest., 31, 789-797.

Refetoff, S., DeWind, L. T., and DeGroot, L. J.' (1967). Familial syndrome combining deaf-mutism, stippled epiphyses, goiter and abnormally high PBI: possible target organ refractoriness to thyroid hormone. J. clin. Endocr., 27, 279-294.

Refetoff, S., and Selenkow, H. A. (1966). Familial thyroxine-binding globulin deficiency in a patient with Turner's syndrome (XO). Genetic study of a kindred. New Engl. J. Med., 278, 1081-1087.

Reichlin, S., Koussa, M. G., and Witt, F. W. (1959). Effect of prolonged sleep therapy and of chlorpromazine on plasma proteinbound iodine concentration and plasma thyroxine turnover. J. clin. Endocr., 19, 692-699.

Reichlin, S., and O'Neal, L. W. (1962). Thyroid hormone levels of the blood after electroshock-induced convulsions in man. $J$. clin. Endocr., 22, 385-388.

Rhodes, B. A. (1968). The circulating iodotyrosines. Acta endocr. (Kbh.), 57, Suppl., 127.

Richie, J. L. (1959). Acute suppurative thyroiditis in a child. Amer. J. Dis. Child., 97, 493-494.

Rifkind, B. M., and Boyle, J. A. (1967). Blood lipid levels, thyroid status and glucose tolerance in progressive partial lipodystrophy. J. clin. Path., 20, 52-55.

Rimoin, D. L. (1965). Thyroxine-binding proteins in mongolism. J. clin. Endocr., 25, 708-709.

Ritzel, G., and Herzog, E. (1965). Proteingebundenes Jod unter Trinkwasserfluorierung bei Schulkindern. Schweiz. med. Wschr., 95, 364-365.

Robbins, J. (1954). Thyroglobulin in serum after $I^{131}$ therapy. I. Salting out. J. biol. Chem., 208, 377-386.

Robbins, J., and Rall, J. E. (1952). Zone electrophoresis in filter paper of serum $\mathrm{I}^{131}$ after radioiodide administration. Proc. Soc. exp. Biol. (N.Y.), 81, 530-536.

Robbins, J., and Rall, J. E. (1957). The interaction of thyroid hormones and protein in biological fluids. Recent Progr. Hormone Res., 13, 161-208.

Robbins, J., and Rall, J. E. (1960). Proteins associated with the thyroid hormones. Physiol. Rev., 40, 415-489.

Robbi s, J., and Rall, J. E. (1967). The iodine containing hormones. In Hormones in Blood, edited by C. H. Gray and A. L. Bacharach, 2nd ed., vol. 1, pp. 383-490. Academic Press, London.

Robbins, J., Rall, J. E., and Petermann, M. L. (1957). Thyroxinebinding by serum and urine proteins in nephrosis. Qualitative aspects. J. clin. Invest., 36, 1333-1342.

Robbins, J., Rall, J. E., and Rawson, R. W. (1955). A new serum iodine component in patients with functional carcinoma of the thyroid. J. clin. Endocr., 15, 1315-1331.

Robey, J. S., Veazey, P. M., and Crawford, J. D. (1956). Cobaltinduced myxedema. Report of a case. New Engl. J. Med., 255, 955-957.

Roche, M., and Layrisse, M. (1956). Effect of cobalt on thyroidal uptake of I $^{131}$. J. clin. Endocr., 16, 831-833.

Roitt, I. M., and Torrigiani, G. (1967). Identification and estimation of undegraded thyroglobulin in human serum. Endocrinology, 81, 421-429.

Rose, H., Russell, K. P., and Starr, P. (1963). Serum protein-bound iodine of mothers and infants at delivery in premature and term pregnancies. Amer. J. Obstet. Gynec., 86, 767-771.

Rosewater, S., Gwinup, G., and Hamwi, G. J. (1965). Familial gynecomastia. Ann. intern. Med., 63, 377-385.

Rosin, A. J., and Farran, H. E. A. (1968). Factors influencing in vitro tests of thyroid function in the elderly. J. Amer. Geriat. Soc. 16, 1030-1038

Roth, J., Glick, S. M., Cuatrecasas, P., and Hollander, C. S. (1967) Acromegaly and other disorders of growth hormone secretion. Combined clinical staff conference at the National Institutes of Health. Ann. intern. Med., 66, 760-788.

Row, V. V., Volpé, R., and Ezrin, C. (1966). ${ }^{127}$ I-iodotyrosine-like compounds in normal human serum. Clin. chim. Acta, 13, 666-668.

Rundle, A. T., Fannin, C. V., and Sylvester, P. E. (1966). Serum protein-bound iodine and phenylketonuria. J. ment. Defic. Res., 10, 287-290.

Rupp, J. J., Chavarria, C., Paschkis, K. E., and Chublarian, E. (1959). The occurrence of tri-iodothyronine as the only circulating thyroid hormone. Ann. intern. Med., 51, 359-362.
Rupp, J. J., and Paschkis, K. E. (1961). The changing pattern of circulating iodinated amino acids in a case of thyrotoxicosis. Amer. J. Med., 30, 472-474.

Ryckewaert, A., Massé, C., Jurmand, S. H., Caroit, M., Durieu, J., Guérin, C., and Séze, S. de (1967). Goutte et myxoedème. Sem. Hóp. Paris, 43, 3059-3062.

Sakurada, T. (1965). Separation of human thyroid hormones by thin layer chromotography. Tohoku J. exp. Med., 85, 365-373.

Sakurada, T. (1966). Separation and quantitative determination of human thyroid hormones by thin layer chromatography. Tohoku J. exp. Med., 88, 367-372.

Scazziga, B. R., Lemarchand-Béraud, T., and Vannotti, A. (1964). La fonction thyroidienne dans la sénescence. Nouvelles données concernant le transport plasmatique des hormones thyroidiennes. Schweiz. med. Wschr., 94, 1778-1782.

Schatz, D. L. (1967). Serum free thyroxine and thyroxine-binding protein studies in patients with supraventricular tachycardias. J. clin. Endocr., 27, 165-172.

Schatz, D. L., Sheppard, R. H., Palter, H. C., and Jaffri, M. H. (1967) Thyroid function studies in fasting obese subjects. Metabolism, 16, 1075-1085.

Schmidt-Kessen, W. (1967). Therapie mit den Klimaelementen im Mittelgebirge. Arch. phys. Ther. (Lpz.), 19, 327-334.

Schteingart, D. E., Perlmutter, M., and Numeroff, M. (1960). Effect of diuretics upon the serum protein bound iodine and the thyroidal uptake of radioactive iodine. Amer. J. med. Sci., 239, 571-577.

Sedvall, G., Jönsson, B., Pettersson, U., and Levin, K. (1968). Effects of lithium on plasma protein bound iodine and uptake of $I^{13}$ in thyroid gland of man and rat. Life Sci., 7, 1257-1264.

Sehgal, V. N., and Basu, A. K. (1967). Thyroid function in leprosy as determined by uptake of radioactive iodine. Int. J. Leprosy. $35,58-59$.

Selenkow, H. A., Rivera, A., and Thorn, G. W. (1957). The effects of amphenone on thyroid function in man. J. clin. Endocr., 17, 1131-1140.

Selzer, M. L., and VanHouten, W. H. (1964). Normal thyroid function in chronic alcoholism. J. clin. Endocr., 24, 380-382.

Sendrail, M., Bru, A., and Blum, C. (1966). Hypercaptation thyroìdienne et décharge iodée sous insulinisation dans un cas de saturation médicamenteuse. Ann. Endocr. (Paris), 27, 814-819.

Shalom, E. S. (1966). Iodinated constituents of plasma of normal subjects and of patients suffering from thyrotoxicosis. $J$. Endocr., 36, 1-6.

Shambaugh, G. E., III, and Beisel, W. R. (1967). Early alterations in thyroid hormone physiology during acute infection in man. J. clin. Endocr., 27, 1667-1673.

Sharpe, A. R., Jr. (1961). Inhibition of thyroidal I ${ }^{131}$ uptake by parabromdylamine maleate. J. clin. Endocr., 21, 739-740.

Shepard, T. H., Pyne, G. E., Kirschvink, J. F., and McLean, M (1960). Soybean goiter. Report of three cases. New Engl. J. Med., 262, 1099-1103.

Sherer, M. G., and Siefring, B. N. (1956). Effect of prednisone and prednisolone on thyroid function, with special reference to thyroxine-binding protein in nephrosis. J. clin. Endocr., 16, 643-652.

Shimaoka, K. (1963). Toxic adenoma of the thyroid with triiodothyronine as the principal circulating thyroid hormone. Acta endocr. (Kbh.), 43, 285-293.

Shipley, R. A., and Chudzik, E. B. (1957). Thyroidal uptake and plasma clearance of $\mathrm{I}^{131}$ and $\mathrm{I}^{127}$ in cirrhosis of the liver. J. clin. Endocr., 17, 1229-1236.

Shurygin, D. I., Komarova, T. F., Murchakova, A. P., Sokolova, E. V. and Tendler, D. S. (1967). Peculiarities of the thyroid function in leucosis and lymphogranulomatosis. (Russian.) Vop. Onkol., 13 (9), 61-65.

Sicher, K., and Waterhouse, J. A. H. (1967). Thyroid activity in relation to prognosis in mammary cancer. Brit. J. Cancer, 21, 512518.

Siersbaeck-Nielsen, K., and Hansen, J. M. (1969). Variations in plasma thyroxine during labour and early puerperium. Acta endocr. (Kbh.), 60, 423-432.

Silverstein, G. E., Burke, G., and Cogan, R. (1967). The natural history of the autonomous hyperfunctioning thyroid nodule. Ann. intern. Med., 67, 539-548.

Simbari, R. D., and Houghton, E. (1969). Distortion of PBI determination during coronary care. Arch. intern. Med., 123, 597. 
Similä, S., Rosberg, G., and Pystynen, P. (1967). The role of radioiodinated human serum albumin placentography and amidotrizoate angiography during pregnancy in the assessment of the newborn proteinbound iodine. Ann. Paediat. Fenn., 13, 96-99.

Simpson, G. M., Cranswick, E. H., and Blair, J. H. (1964). Thyroid indices in chronic schizophrenia. II. J. nerv. ment. Dis., 138, 581-585.

Singh, B. P., and Morton, D. G. (1956). Blood protein-bound iodine determinations as a measure of thyroid function in normal pregnancy and threatened abortion. Amer. J. Obstet. Gynec., 72, 607-614.

Siri, W. E., Dyke, D. C. van, Winchell, H. S., Pollycove, M., Parker, H. G., and Cleveland, A.S. (1966). Early erythropoietin, blood, and physiological responses to severe hypoxia in man. J. appl. Physiol., 21, 73-80.

Sisson, J. C. (1965). Principles of, and pitfalls in, thyroid function tests. J. nucl. Med., 6, 853-901.

Sisson, J. C., Marshall, B. R., Byall, B. A., and Capps, R. D. (1967). Serum protein-bound iodine and resin uptake of triiodothyronine during normal pregnancy. Univ. Mich. med. Center J., 33, 231-233.

Skillern, P. G. (1964). Thyroiditis. In The Thyroid Gland, edited by R. Pitt-Rivers and W. R. Trotter, vol. 2, pp. 130-150. Butterworth, London.

Slater, S., and Numeroff, M. (1961). Iodine-containing medications, the protein-bound iodine and the uptake of radioiodine by the thyroid gland. New Engl. J. Med., 264, 449-450.

Smeenk, D., and Brand, I. B. A. M. van den (1965). De invloed van de lichaamshouding op hematocriet en het gehalte aan eiwit, calcium, cholesterol en PBI van het bloed. Ned. T. Geneesk, 109, 1798-1800.

Sönksen, P. H., Ekins, R. P., Stevens, H. G., Williams, E. S., and Nabarro, J. D. N. (1968). Serum-levels of protein-bound iodine and thyroxine after a course of clioquinol. Lancet, 2 , 425-426.

Spellacy, W. N., and Cohen, W. D. (1967). Clomiphene treatment of prolonged secondary amenorrhea associated with pituitary gonadotropin deficiency. Amer. J. Obstet. Gynec., 97, 943-948.

Stanbury, J. B., Goldsmith, R. R., and Gillis, M. (1954). Myotonic dystrophy associated with thyroid disease. J. clin. Endocr., 14, 1437-1443.

Stanbury, J. B., and Janssen, M. A. (1962). The iodinated albuminlike component of the plasma of thyrotoxic patients. J. clin. Endocr., 22, 978-988.

Stanbury, J. B., and Morris, M. L. (1957). The metabolism of 3:3'diiodothyronine in man. J. clin. Endocr., 17, 1324-1331.

Staquet, M. (1965). Modifications de l'iode protidique du sérum chez l'homme exposé à un climat polaire. J. Physiol. (Paris), 57, 499502.

Starr, P., and Nicoloff, J. (1967). Comparison of serum protein bound iodine and thyroxine binding globulin saturation capacity values in negro and white school children: ethnic difference. Acta endocr. (Kbh.), 56, 577-584.

Starr, P., Petit, D. W., Chaney, A. L., Rollman, H., Aiken, J. B. Jamieson, B., and Kling, I. (1950). Clinical experience with the blood protein-bound iodine determination as a routine procedure. J. clin. Endocr., 10, 1237-1250.

Steigbigel, N. H., Oppenheim, J. J., Fishman, L. M., and Carbone, P. P. (1964). Metastatic embryonal carcinoma of the testis associated with elevated plasma TSH-like activity and hyperthyroidism. New Engl. J. Med. 271, 345-349.

Steinberg, M., and Leif heit, H. C. (1965). Effect of Metrecal on serumprecipitable iodine values. Tex. Rep. Biol. Med., 23, 122-127.

Stephenson, J. N., Mellinger, R. C., and Manson, G. (1968). Cerebral gigantism. Pediatrics, 41, 130-138.

Sterling, K., Bellabarba, D., Newman, E. S., and Brenner, M. A. (1969). Determination of triiodothyronine concentration in human serum. J. clin. Invest., 48, 1150-1158.

Sterling, K., and Brenner, M. A. (1966). Free thyroxine in human serum: simplified measurement with the aid of magnesium precipitation. J. clin. Invest., 45, 153-163.

Stewart, R. D. H., and Grayson, M. F. (1966). The effect of long-term phenindione treatment on thyroid function. Scot. med. J., $11,360-363$.

Strang, R. R. (1968). Parkinson's disease presenting as hypothyroidism. Dis. nerv. Syst., 29, 396-398.

Surks, M. I. (1966). Elevated PBI free thyroxine, and plasma protein concentration in man at high altitude. J. appl. Physiol., 21, 1185-1190.
Surks, M. I., Beckwitt, H. J., and Chidsey, C. A. (1967). Changes in plasma thyroxine concentration and metabolism, catecholamine excretion and basal oxygen consumption in man during acute exposure to high altitude. J. clin. Endocr., 27, 789-799.

Surks, M. I., and Oppenheimer, J. H. (1969). Formation of iodoprotein during the peripheral metabolism of 3,5,3'-triiodo-Lthyronine-125I in the euthyroid man and rat. J. clin. Invest., 48, 685-695.

Suzuki, H., Higuchi, T., Sawa, K., Ohtaki, S., and Horiuchi, Y. (1965). 'Endemic coast goitre' in Hokkaido, Japan. Acta endocr. (Kbh.), 50, 161-176.

Suzuki, M., Tonoue, T., Matsuzaki, S., and Yamamoto, K. (1967). Initial response of human thyroid, adrenal cortex, and adrena medulla to acute cold exposure. Canad. J. Physiol. Pharmacol. $45,423-432$.

Szántó, L., and Reviczky, A. L. (1966). Thyroid function during longterm treatment with the serotonin-antagonist lysergic acid butanolamide. Acta physiol. Acad. Sci. hung., 30, 233-240.

Szántó, L., Reviczky, A. L., and Grynaeus, T. (1964). Effect of a mono-aminooxydase inhibitor (nialamide) on thyroid activity. Acta physiol. Acad. Sci. hung., 25, 241-254.

Szobor, A., and Környey, E. (1966). Myasthenia gravis und Dysthyreosis. Nervenarzt, 37, 337-342.

Tanaka, S., and Starr, P. (1959). Clinical observations on serum globulin thyroxine-binding capacity, using a simplified technique. J. clin. Endocr., 19, 84-91.

Taubert, H.-D., Haskins, A. L., and Moszkowski, E. F. (1966). The influence of thioridazine upon urinary gonadotropin excretion. Sth. med. J. (Bgham, Ala.), 59, 1301-1303.

Taurog, A. (1963). Spontaneous deiodination of $I^{131}$-labeled thyroxine and related iodophenols on filter paper. Endocrinology, 73, 45-62.

Taylor, S. (1953). The evolution of nodular goiter. J. clin. Endocr., $13,1232-1247$.

Tenzel, R. R. (1968). Comments on superior limbic filamentous keratitis: Part 2. Arch. Ophthal., 79, 508.

Tervilä, L., and Nordman, R. (1966). Dependence of fetal PBI and cholesterol on maternal values. Ann. Chir. Gynaec. Fenn., 55, 298-300.

Theodore, F. H. (1968). Comments on findings of elevated proteinbound iodine in superior limbic keratoconjunctivitis: Part I. Arch. Ophthal., 79, 508.

Thompson, E. M., and Kight, M. A. (1963). Effect of high environmental temperature on basal metabolism and concentrations of serum protein-bound iodine and total cholesterol. Amer. J. clin. Nutr., 13, 219-225.

Thomson, J. A., Boyle, I. T., McGirr, E. M., MacDonald, E. M., Nicol, J., and Brown, J. (1968). Evaluation of discordant laboratory data in patients with thyroid disorders. $J$. clin. Path., 21, 511-517.

Tingley, J. O., Morris, A. W., Hill, S. R., Jr., and Pittman, J. A., Jr. (1965). The acute thyroid response to emotional stress. Ala. J. med. Sci., 2, 297-300.

Tishler, P. V., and Ingbar, S. H. (1966). Studies of thyroid economy in two patients with phenylketonuria. J. clin. Endocr., 26, 661665.

Tong, W., Taurog, A., and Chaikoff, I. L. (1952). Nature of plasma iodine following destruction of the rat thyroid with $1^{131}$. J. biol. Chem., 195, 407-413.

Trotter, W. R. (1962). Diseases of the Thyroid. Blackwell, Oxford.

Turkington, R. W., and Lebovitz, H. E. (1967). Extra-adrenal endocrine deficiencies in Addison's disease. Amer. J. Med., 43, 499-507.

Valenti, G., and Coscelli, C. (1966). Sulla capacità delle proteine sieriche di fissare gli ormoni tiroidei nella senescenza normale e patologica. G. Geront., 14, 319-329.

Vannotti, A., and Béraud, T. (1959). Functional relationships between the liver, the thyroxine-binding protein of serum, and the thyroid. J. clin. Endocr., 19, 466-477.

Wyck, J. J. van, Arnold, M. B., Wynn, J., and Pepper, F. (1959). The effects of a soybean product on thyroid function in humans. Pediatrics, 24, 752-760.

Vivacqua, R. J., Haurani, F. I., and Erslev, A. J. (1967). 'Selective' pituitary insufficiency secondary to busulfan. Ann. intern. Med., 67, 380-387.

Volpé, R., Vale, J., and Johnston, M. W. (1960). The effects of certain physical and emotional tensions and strains on fluctuations in the level of serum protein-bound iodine. J. clin. Endocr., 20, 415-428.

Volpert, E. M., Martinez, M., and Oppenheimer, J. H. (1967). Radioiodinated impurities in commercial preparations of ${ }^{131} \mathrm{I}$ - 
thyroxine and their effect on the measurement of free thyroxine in human serum by equilibrium dialysis. J. clin. Endocr., 27, 421-428.

Vought, R. L., London, W. T., and Brown, F. A. (1964). A note on atmospheric iodine and its absorption in man. J. clin. Endocr., $24,414-416$.

Walker, P. C., Carney, P., and Gates, E. F. (1964). Testicular feminization. Report of a case with chromosomal studies. Amer. J. clin. Path., 41, 297-301.

Wase, A. W., Repplinger, E., and Foster, W. C. (1953). The effect of anesthetic agents on the thyroid activity of the rat. Endocrino$\log y, 53,630-632$.

Watanabe, G.-I., Aoki, S., and Nagai, T. (1956). Climatic effect on circulating eosinophil count. J. appl. Physiol., 9, 461-464.

Watanabe, G.-I., Uematsu, M., and Horii, K.-I. (1963). Diphasic seasonal variation of the serum protein-bound iodine level. J. clin. Endocr., 23, 383-386.

Wayne, E. J. (1960). Clinical and metabolic studies in thyroid disease. Brit. med. J., 1, 1-11 and 78-90.

Wayne, E. J., Koutras, D. A., and Alexander, W. D. (1964). Clinical Aspects of Iodine Metabolism. Blackwell, Oxford.

Weinert, H., Masui, H., Radichevich, I., and Werner, S. C. (1967). Materials indistinguishable from iodotyrosines in normal human serum and human serum albumin. J. clin. Invest., 46, 1264-1274.

Wellby, M. L., and O'Halloran, M. W. (1969). The iodotyrosine content of normal human serum. Biochem. J., 112, 543-544.

Werner, S. C., Block, R. J., Mandl, R. H., and Kassenaar, A. A. H. (1957). Pathogenesis of a case of congenital goiter with abnormally high levels of SPI and with mono- and diiodotyrosine in the serum. J. clin. Endocr., 17, 817-831.

Werner, S. C., Row, V. V., and Radichevich, I. (1960). Nontoxic nodular goiter with formation and release of a compound with the chromatographic mobility characteristics of triiodothyronine. J. clin. Endocr., 20, 1373-1383.

West, C. D., Wayne, A. W., and Chavré, V. J. (1965). Thin-layer chromatography for thyroid hormones. Analyt. Biochem., 12, 41-48.

Westphal, M., and Man, E. B. (1962). Serum butanol-extractable iodine following exchange transfusion. J. clin. Endocr., 22, 452-456.

Wieland, R. G., Vorys, N., Folk, R. L., Besch, P. K., Neri, A., and Hamwi, G. J. (1966). Studies of female hirsutism. Clinical and biochemical evaluation. Amer. J. Med., 41, 927-934.

Wikholm, G., and Einhorn, J. (1963). Effect of prednisolone and triiodothyronine on thyroid function in hyperthyroidism. J. clin. Endocr., 23, 76-80.

Wilber, J. F., and Odell, W. D. (1965). Influence of tapazole upon

\section{Appendix I}

\section{List of Drugs which May Cause Disturbances in the} Serum Protein-bound Iodine

Drugs marked with an asterisk are considered likely to interfere with serum PBI determinations in therapeutic doses.

\section{DRUGS AND PREPARATIONS CONTAINING IODINE}

The drugs and preparations listed in this section, with the exception of a few for which specific references are given, appear in Martindale's Extra Pharmacopoeia (25th ed, 1967), in Medindex (Jan.-March 1967) or in Wayne et al (1964, Appendix II). Some pharmacological details were obtained from Iodine Pharmaceuticals (1952, 3rd supplement, 1956) published by the Chilean Iodine Educational Bureau, which contains an extensive list of serum TSH. J. clin. Endocr., 25, 1407-1408.

Williams, E. D., and Doniach, I (1961). The antithyroid activity of the anti-coagulant phenylindanedione. $J$. Endocr., 21, 421-431.

Williams, E. D., and Doniach, I. (1962). The post-mortem incidence of focal thyroiditis. J. Path. Bact., 83, 255-264.

Wilson, O. (1966). Field study of the effect of cold exposure and increased muscular activity upon metabolic rate and thyroid function in man. Fed. Proc., 25, 1357-1362.

Winikoff, D. (1968). Oral contraceptives and thyroid function tests: the role of progestogens. Med.J. Aust., 2, 13-18.

Woeber, K. A., and Ingbar, S. H. (1964). The effects of noncalorigenic congeners of salicylate on the peripheral metabolism of thyroxine. J. clin. Invest., 43, 931-942.

Woeber, K. A., and Ingbar, S. H. (1968). The contribution of thyroxine-binding prealbumin to the binding of thyroxine in human serum, as assessed by immunoadsorption. $J$. clin. Invest., 47, 1710-1721.

Wolff, J. (1969). Iodide goiter and the pharmacologic effects of excess iodide. Amer. J. Med., 47, 101-124.

Wolff, J., Standaert, M. E., and Rall, J. E. (1961). Thyroxine displacement from serum proteins and depression of serum proteinbound iodine by certain drugs. J. clin. Invest., 40, 1373-1379.

Wolff, J., Thompson, R. H., and Robbins, J. (1964). Congenital goitrous cretinism due to the absence of iodide-concentrating ability. J. clin. Endocr., 24, 699-707.

Wood, L. C., Olichney, M., Locke, H., Crispell, K. R., Thornton, W. N., Jr., and Kitay, J. I. (1965). Syndrome of juvenile hypothyroidism associated with advanced sexual development: report of two new cases and comment on the management of an associated ovarian mass. J. clin. Endocr., 25, 1289-1295.

Woolner, L. B., McConahey, W. M., and Beahrs, O. H. (1957). Invasive fibrous thyroiditis (Riedel's struma). J. clin. Endocr. 17, 201-220.

Wyngaarden, J. B., Wright, B. M., and Ways, P. (1952). The effect of certain anions upon the accumulation and retention of iodide by the thyroid gland. Endocrinology, 50, 537-549.

Yamada, T., Whallon, J., Tomizawa, T., Shimoda, S.-I., and Shichijo, K. (1965). Further studies on the mechanism of action of trypan blue and related dyes in suppressing thyroid activity in the rat. Metabolism, 14, 281-290.

Zak, B., Willard, H. H., Myers, G. B., and Boyle, A. J. (1952). Chloric acid method for determination of protein-bound iodine. Analyt. Chem., 24, $1345-1348$.

Zingg, W., and Perry, W. F. (1953). The influence of adrenal and gonadal steroids on the uptake of iodine by the thyroid gland. J. clin. Endocr., 13, 712-723.

Zucker-Franklin, D., Rifkin, H., and Jacobson, H. G. (1968). Werner's syndrome. An analysis of ten cases. Geriatrics, 23 (8), 123-135.

iodine preparations, including many less common ones. Further data were kindly provided by $\mathrm{Dr}$ W. W. Snedden of the Chilean Iodine Educational Bureau and by the Library of the Pharmaceutical Society.

All the compounds listed in this section contain iodine in inorganic or organic combination, and either have been reported to, or could potentially, affect tests of thyroid function. This does not, however, mean that changes in serum PBI would necessarily follow their administration. Their possible effect on the serum PBI of an individual patient must be assessed in relation to the dose taken and to the composition of the preparation concerned.

Topical applications (including antiseptics and oral disinfectants) Acnosil contains iodine (quantity unspecified)

Adrepatine suppositories contain $10 \mathrm{mg}$ fresh thyroid gland

${ }^{1}$ Some sun tan oil preparations contain iodine (Chapman and Maloof, 1955). 
Anerythene ( $=$ H.E.B. 'A')

Antiru cream contains $0.0125 \% \mathrm{NaI}$

Arctic Glow menthol and wintergreen cream contains $1 \% \mathrm{KI}$

*Arthene volatile iodine rub contains $0.25 \%$ phenylethyl iodide

(57\% I) and $1 \%$ terpineol iodide $(45.5 \% \mathrm{I})$

*Ayrton's iodized throat tablets contain $0.3 \mathrm{mg}$ of $\mathrm{I}_{2}$ and $0.3 \mathrm{mg}$ of $\mathrm{KI}$

*B.F.I. powder contains $16 \% \mathrm{w} / \mathrm{w}$ bismuth-formic-iodide

Balmosa iodized contains $1.2 \% \mathrm{NaI}$

Balto foot balm contains $0.25 \% \mathrm{KI}$

*Barquinol cream contains clioquinol (concentration not specified)

*Betadine (= Povidone Iodine)

*Betnovate-C contains $3 \%$ clioquinol

*Bijogalum (= bismuth oxyiodogallate)

Bismoid contains sodium resorcinol iodide (quantity not specified)

*Bismuth-Formic-Iodide. A mixture containing thymol iodide and

bismuth oxyiodide

*Bismuth oxyiodide contains $35 \%$ I

*Bismuth oxyiodogallate contains at least $20 \%$ I

*Bismuth oxyiodosubgallate (= bismuth oxyiodogallate)

*Calmitol ointment contains $9.6 \mathrm{mg}$ of $\mathrm{I}_{2}$ per $100 \mathrm{~g}$

*Calot's fluid contains $10 \%$ iodoform

*Calot's no. 2 paste contains $4 \%$ iodoform

Chibret iodo-chloride collyrium contains $0.5 \% \mathrm{KI}$

*Cor-Tar-Quin contains $1 \%$ di-iodohydroxyquinoline

Cuprodine contains $0.1 \%$ lauryl iodide (31\% I)

*Diphenyliodinium phthalimide contains $39 \%$ I

*Diphenyliodonium acetate contains $43 \%$ I

*Diphiodin 1.G.62 (cream or solution) contains $0.3 \%$ I (organic)

Dols' impregnated fiannel (impregnating solution contains $1 \cdot 25 \% I_{2}$ )

Dols' rub cream contains $0.25 \% \mathrm{KI}$

*Domeform-HC contains $3 \%$ clioquinol

*Donovan's solution contains $1 \% \mathrm{AsI}_{\mathbf{3}}$ and $1 \% \mathrm{HgI}_{\mathbf{2}}$

*E.D.P. (Evans dusting powder) contains $4 \cdot 18 \%$ bismuth oxyiodide and $1 \cdot 14 \%$ thymol iodide

*Ecothiopate (iodide) contains 33\% I

*Echothiopate (= Ecothiopate)

Endoarsan contains $0.2 \% \mathrm{NaI}$ and $0.1 \% \mathrm{HgI}_{2}$

*Faringets lozenges contain $0.8 \mathrm{mg}$ of I (organic)

*H.E.B. 'A' contains 0.19\% I (organic)

*H.E.B. S.S. contains $0.5 \%$ diphenyliodonium acetate

*H.E.B. calamine cream contains $0.5 \%$ diphenyliodonium acetate

*Hamolen suppositories contain bismuth oxyiodogallate and tri-

iodoresorcinol

*I.B. paint contains $1.25 \% \mathrm{I}_{2}$ and $1.25 \% \mathrm{KI}$

*Iglodine contains $0.04 \%$ combined iodine

* Iglodine ointment contains $0 \cdot 14 \%$ combined iodine

*Iglodine salicylated contains $0.32 \%$ combined iodine

*Iodex contains $4 \%$ I,

*Iodine glycerin contains $2.28 \% \mathrm{I}_{2}$ and $6.86 \% \mathrm{KI}$

Iodized cream (Thomson's) contains $0.05 \% \mathrm{NaI}$

*Iodoform contains $97 \%$ I

*Iodoglycerin solution (= iodine glycerin)

*Iodopix contains $1 \%$ clioquinol

*Locorten-Vioform contains 3\% clioquinol

Lumuscoba impregnated pad. Impegnating solution contains $0.4 \%$ $\mathrm{NaI}$

Medicoids suppositories contain $0.5 \%$ bismuth oxyiodide

*Mencières solution A contains $10 \%$ iodoform

* Mencières solution B contains $1 \%$ iodoform

*Mentex embrocation contains $0.075 \% \mathrm{I}_{2}$

*Morton's fluid (= iodine glycerin)

N.H. \& S. balm contains $0.009 \%$ combined iodine

*N.P.U. liquid antiseptic contains $0 \cdot 15 \% \mathrm{I}_{2}$

*Nasciodine contains $1.25 \% \mathrm{I}_{2}$

Neoprotosil ointment contains $1 \%$ AgI

*Nystaform-HC (lotion or ointment) contains 3\% clioquinol

*Parisepsin diphiodin contains diphenyliodinium phthalimide (concentration not stated)

*Paton's mouth treatment contains $0.05 \%$ iodoform
*Phospholine (= Ecothiopate)

* Povidone-Iodine contains $9-12 \%$ available iodine

*Proviodine (= Povidone-Iodine)

*Quinaband zinc paste and calamine bandage contains clioquinol

*Radosene contains $2 \%$ phenylethyliodide (55\% I)

Riddorheum liquid contains $1 \cdot 2 \% \mathrm{NH}_{4} \mathrm{I}$

*Rozental's paste contains $2 \%$ w/w $\mathrm{I}_{2}$

*Scholl's (Dr) bunion lotion contains $2.7 \% \mathrm{I}_{2}$ and $2.7 \% \mathrm{KI}$

*Sedresol ointment contains $0.42 \%$ thymol iodide

Sorosil contains $0.006 \% \mathrm{I}_{2}$

Sure Shield iodized throat lozenges contain $0.0478 \% I_{2}$ (free and combined)

Surgaseptic antiseptic throat tablets contain $0.075 \% \mathrm{w} / \mathrm{w}$ of organically bound iodine

Surgaseptic effervescing mouth wash tablets contain $0.15 \% \mathrm{w} / \mathrm{w}$ of organically bound iodine

*Surgaseptic germicide contains $0.15 \%$ of organically bound iodine

*Surgaseptic ointment contains $\mathbf{1 2 . 7 5} \mathrm{mg}$ of organically bound iodine per $100 \mathrm{~g}$

*Surgaseptic pile suppositories contain $1.5 \mathrm{mg}$ of organically bound iodine

* Synalar-C ointment contains 3\% clioquinol

*T.B.P. hair and scalp treatment contains $0.01 \%$ 'iodosalicylic' acid *T.C.P. $B_{3}$ colloidal emulsion contains $0.08 \%$ of organically bound iodine

T.C.P. first aid cream contains $0.04 \%$ of organically bound iodine

*T.C.P. liquid antiseptic contains $0.11 \%$ of organically bound iodine

T.C.P. ointment contains $0.07 \%$ of organically bound iodine, $0.01 \%$ $I_{2}$ and $0.02 \% \mathrm{KI}$

T.C.P. throat pastilles contain $0.01 \%$ of organically bound iodine

*Talbot's solution contains $4.1 \% \mathrm{I}_{2}$ and $2.5 \% \mathrm{ZnI}_{2}$

*Thymol iodide contains $43 \%$ I

*Tucal lozenges contain $0.03 \%$ iodophenol $(57.5 \% \mathrm{I})$

*Ucal safety first iodized throat lozenges contain $0.2 \mathrm{mg}$ of $\mathrm{I}_{2}$ and $0.4 \mathrm{mg}$ of $\mathrm{KI}$

*Undecoylium chloride-iodine contains about $\mathbf{4 0 \%}$ I

*Vanodine contains $1.9 \%$ of available iodine

*Venotone cream contains $0.009 \% \mathrm{w} / \mathrm{w}$ I

Verucol contains $0 \cdot 1 \% \mathrm{HgI}_{\text {, }}$

Virac ( = undecoylium chloride-iodine)

Wismutoxyjodidgallat ( $=$ bismuth oxyiodogallate)

Expectorants, antispasmodics, diuretics, and analgesics

AM 49 contains KI (quantity not specified)

Aciform II (for arthritis) contains iodine (quantity not specified)

Alogeral contains iodocasein (quantity not specified)

*Alostorin tablets contain $0.075 \mathrm{~g}$ of iodocasein

*Ambrosia lactation tablets contain $30 \mathrm{mg}$ of $I_{2}$

Aminocortiode (composition not stated)

Aminural contains KI (quantity not specified)

*Amiodoxyl benzoate (= ammonium $o$-iodoxybenzoate)

*Ammonium o-iodoxybenzoate contains $45 \%$ I

*Amsa tablets contain $65 \mathrm{mg}$ of $\mathrm{KI}$

Analeptine contains $\mathrm{NaI}$ (concentration not specified)

Antipyrine iodide (= phenazone iodide)-not manufactured now

*Anaspasmine contains 1.3\% KI

*Antasma tablets contain $12.28 \% \mathrm{KI}$

*Anti-arthritis tablets (Sumner) contain $195 \mathrm{mg}$ of KI

*Asthma Dellipsoids D17 contain 22 mg of CaI,

Auricol contains $\mathrm{SrI}_{2}$ (concentration not specified)

Aurubin contains $\mathrm{AuI}_{3}$ and $\mathrm{CaI}_{2}$ (concentrations not specified)

Bellapurin suppositories contain $0.002 \mathrm{~g}$ of $\mathrm{SrI}_{2}$

Bethiodyl contains KI (concentration not specified)

Broncholysin contains organic iodine (compound and quantity not specified)

*Bronchotone contains 1.15\% NaI

*Brovonex contains $5 \%$ caffein and sodiod and $3.25 \% \mathrm{NaI}$

*C.M.P. asthma remedy contains $8.3 \%$ caffein and sod iod, $8.3 \% \mathrm{NaI}$ and $0.625 \% \mathrm{HI}$ 
Caffedrin contains di-iodocaffein hydroiodide (quantity not specified)

*Caffein and sod iod (B.P.C.) contains 50-53\% NaI

*Caffeine iodide (= di-iodocaffeine hydriodide)

* Caffeine tri-iodide ( $=$ di-iodocaffeine hydriodide)

*Caffexen contains $9 \cdot 14 \%$ caffein and sod iod and $9 \cdot 14 \% \mathrm{NaI}$

* Calcidin contains $15 \%$ of available iodine

*Calcidrine syrup contains $4 \% \mathrm{KI}$

*Candine contains $5.4 \%$ di-iodocaffeine hydriodide

*Caphedrodine contains $9 \cdot 1 \%$ caffein and sod iod and $9.1 \% \mathrm{NaI}$

Colloidine contains 'colloidal iodine' (quantity not specified)

Colsalide contains KI (quantity not specified)

*Creolix contains $2.5 \% \mathrm{NaI}$

*Dainite KI (Grayson, 1960)

Deka contains KI (quantity not specified)

*Di-iodocaffeine hydriodide contains $66.5 \%$ I

*Epicaffneine contains $9 \cdot 1 \%$ caffein and sod iod, $9 \cdot 1 \% \mathrm{NaI}$ and $0.83 \%$ HI

*Ephedrine compound elixir contains $1.25 \% \mathrm{NaI}$

*Euphorbia (as mist euphorbia Co) contains $3.4 \% \mathrm{KI}$

*Eupinal contains $6.9 \% \mathrm{NH}_{4} \mathrm{I}$

*Eupnine contains $14 \%$ di-iodocaffeine hydriodide

*Felsol powders contain $12 \mathrm{mg}$ of $\mathrm{I}_{2}$ combined with $18 \mathrm{mg}$ of phenzone

*Hair's (Dr) asthma remedy contains $0.3 \% \mathrm{NaI}$ and $5.1 \% \mathrm{KI}$

*Hair's (Dr) asthma remedy pastilles contain $14.6 \% \mathrm{w} / \mathrm{w} \mathrm{KI}$ and $0.7 \% \mathrm{w} / \mathrm{w} \mathrm{NaI}$

*Halotheine contains $5.4 \%$ of iodine combined with caffeine

*Hyodin contains $1.4 \%$ I (as $\mathrm{HI}$ )

*Iod Calcium Diuretin tablets contain $100 \mathrm{mg}$ of $\mathrm{KI}$

*Iodinated glycerol contains $50 \%$ I (organic)

*Iodo-caffedrin contains $10 \%$ caffeine and potassium iodide and

$3.65 \% \mathrm{KI}$

* Iodocaffeine (= caffein and sod iod)

*Iodoephedrine contains $2.55 \% \mathrm{NaI}$

*Iodopropylidene dioxypropanol (= iodinated glycerol)

*Iodopropylidene glycerol (= iodinated glycerol)

*Iodopyrine (= antipyrine iodide). See Hydovitz and Rose (1956)

*Kaladex contains $4.4 \% \mathrm{KI}$

*Lobidine contains $0.45 \% \mathrm{KI}$

* Luma antirheumatic compound contains $0.5 \% \mathrm{KI}$

* Luma antirheumatic cubes contain $0.4 \% \mathrm{w} / \mathrm{w} \mathrm{KI}$

*Lydrin contains $4.2 \% \mathrm{NaI}$

* Naiodine contains $2 \% \mathrm{NaI}$

* Naiodine B contains $5 \% \mathrm{NaI}$

* Norisodrine syrup contains $3 \% \mathrm{CaI}_{2}$

*Organidin elixir contains $1.2 \%$ iodinated glycerol

* Organidin solution contains $5 \%$ iodinated glycerol

*Organidin tablets contain $30 \mathrm{mg}$ of iodinated glycerol

Pulmocardine contains $\mathrm{KI}$ and di-iodocaffeine hydriodide (quantities unspecified)

* Rybarex inhalant contains $0.1 \%$ tri-iodophenol ( $81 \% \mathrm{I})$

*Rybronsol powders each contain $30 \mathrm{mg}$ of 'iodophenazone'

* Sibec elixir contains $3.5 \% \mathrm{NaI}$

*Theomine tablets contain $162 \mathrm{mg}$ of $\mathrm{KI}$

*Theo-Organidin contains $0.2 \%$ iodinated glycerol

Thioderazine contains organic iodine (nature and concentration not specified)

*Trisan contains $6.05 \% \mathrm{KI}$

*Tucal linctus contains $0.02 \%$ iodophenol $(57 \cdot 5 \%$ I)

Intestinal disinfectants (including anthelminthics and amoebicides)

*Abitrene (= di-iodohydroxyquinoline)

*Amebastar (= di-iodohydroxyquinoline)

*Amoebindon (= di-iodoquinoline)

*Amoequin (= di-iodoquinoline)

*Anelmid ( = diathiazanine iodide)
*Avlochin ( $=$ chiniofon)

*BW 61-32 (= stilbazium iodide)

*Carbantran contains $10 \%$ of a Bi derivative of clioquinol

* Chiniofon contains $27.5 \%$ I

*Chinioform (= clioquinol)

*Chloroiodohydroxyquinoline (= clioquinol)

*Clioquinol contains $41 \%$ I (see Sendrail et al, 1966; Sönksen, Ekins, Stevens, Williams, and Nabarro, 1968)

*Cloquinate contains $25 \%$ I

*Delvex ( $=$ diathiazanine iodide)

*Diathiazanine iodide contains $24.5 \%$ I

*Di-iodohydroxyquinoline contains $65 \%$ I

Di-iodoquinoline contains $67 \%$ I

-Diodoquin (= di-iodohydroxyquinoline)

*Diodoxyquinoline (= di-iodohydroxyquinoline)

*Direxiode (= di-iodohydroxyquinoline)

*E.B.I. ( = emetine and bismuth iodide) contains $40 \%$ I

*Embequin (= di-iodohydroxyquinoline)

*Enteroquinodine (= di-iodohydroxyquinoline)

*Enteroquinol (= clioquinol)

* Enterosan tablets contain $100 \mathrm{mg}$ of di-iodohydroxyquinoline

*Enteroseptol (= clioquinol)

*Enterovioform tablets contain $250 \mathrm{mg}$ of clioquinol

*Entrin (= clioquinol)

Esjodin II contains iodine (quantity not specified)

*Floraquin tablets contain $100 \mathrm{mg}$ of di-iodohydroxyquinoline

*Iodochlorhydroxyquin (= clioquinol)

*Iodochlorhydroxyquinoline (= clioquinol)

*Iodoquinoline (= chiniofon)

*Iodoquinoline sulphonic acid (= chiniofon)

* Iodoquinoline sulphonic acid with sodium bicarbonate ( $=$ chiniofon)

*Iodothymol contains $46 \%$ I

*Iquinol (= di-iodohydroxyquinoline)

*Moebiquin ( = di-iodohydroxyquinoline)

* Monopar ( = stilbazium iodide)

-Nivembin tablets contain $\mathbf{3 0 0} \mathrm{mg}$ of di-iodohydroxyquinoline

*Pabirex contains $1.75 \%$ clioquinol

*Partel (= diathiazanine iodide)

*Resotren tablets contain $500 \mathrm{mg}$ of cloquinate

* Resotren compositum tablets contain $75 \mathrm{mg}$ of cloquinate and 300 $\mathrm{mg}$ of di-iodohydroxyquinoline

*Savorquin tablets contain $\mathbf{2 0 0} \mathrm{mg}$ of di-iodohydroxyquinoline *Stilbazium iodide contains $22 \%$ I

*Telmid (= diathiazanine iodide)

*Tourista tablets contain $250 \mathrm{mg}$ of clioquinol

* Tramil tablets contain $250 \mathrm{mg}$ of clioquinol

*Travelettes for diarrhoea contain $250 \mathrm{mg}$ of clioquinol

* Treps contain $250 \mathrm{mg}$ of clioquinol

* Tridia sachets contain $125 \mathrm{mg}$ of clioquinol

*Turistum contain $90 \mathrm{mg}$ of clioquinol

*Vioform contains $3 \%$ clioquinol

Thyroid medications and iodine preparations for internal administration "Alphidine tablets contain $\mathbf{3 0} \mathrm{mg}$ of 'assimilable organic iodine'

*Bladderwrack contains up to $0.2 \%$ I

*Butyl di-iodohydroxybenzoate contains $57 \%$ I

Cavolysin masc and fem (ampoules or tablets) contain $60 \mathrm{mg}$ thyroid *Choloxon (= dextrothyroxine)

Conthyrin contains thyroxine and methylthiouracil

* Dethyrona (= dextrothyroxine)

*Dextrothyroxine contains $65 \%$ I

*Diobene (= butyl di-iodohydroxybenzoate)

*Diotroxin tablets contain $90 \mu \mathrm{g}$ thyroxine and $10 \mu \mathrm{g}$ liothyronine

Diuposan tablets contain $130 \mathrm{mg}$ thyroid 
Elityran tablets contain $\mathbf{9 0} \mathbf{m g}$ thyroid

Eltroxin (= thyroxine)

Esjodin I contains iodine (quantity unspecified)

*Fucus (= bladderwrack)

Glandiposan tablets contain $150 \mathrm{mg}$ thyroid

Hormotone tablets contain $6.5 \mathrm{mg}$ thyroid

Hormotone $\mathrm{T}$ tablets contain $3.25 \mathrm{mg}$ thyroid

Incretone contains acid extract from $130 \mathrm{mg}$ of thyroid in each $100 \mathrm{~m}$ Iodal tablets contain $I_{2}$ and $K I$ (quantities not specified)

*Iodalose contain $3 \% \mathrm{I}$ (in organic combination with peptone)

Iodamelis $\mathbf{P}$ contains an iodine-tannin complex (nature and quantity not specified)

*Iodhema contains $11.25 \%$ I (organically bound)

*Iodobehenate (calcium) contains $23.5 \%$ I

*Iodobesin tablets contain $5 \mathrm{mg}$ lipid-free thyroid and $50 \mathrm{mg}$ iodalbumin $(21.5 \% \mathrm{I})$

*Iodocasein contains $15-20 \%$ I

*Iodotannic syrup contains $1 \% \mathrm{w} / \mathrm{w} \mathrm{I}_{2}$

*Iosal tablets contain $\mathbf{3 0} \mathrm{mg}$ thyroid and $30 \mathrm{mg}$ 'assimilable organic iodine'

*Kelpware ( $\boldsymbol{a}$ bladderwrack)

*Levaxin (= thyroxine)

*Liothyronine contains $58.5 \%$

*Lugol's solution contains $5 \% \mathrm{I}$, and $10 \% \mathrm{KI}$

* Lusty's Kelgar perles contain $200 \mathrm{mg}$ bladderwrack

*Lusty's Malted Kelp tablets contain 800 mg bladderwrack

Oestrol tablets contain $22 \mathrm{mg}$ thyroid

Orchitone tablets contain $22 \mathrm{mg}$ thyroid

Proloid ( $=$ thyroid)

* Saiodine (= calcium iodobehenate)

Scripac ( = thyroid)

* Seawrack (a bladderwrack)

*Synthroid ( = thyroxine)

*Tertroxin (= liothyronine)

Thionaiodine $\mathrm{V}$ tablets contain NaI (quantity not specified)

Thyranon ( $=$ thyroid)

Thyreototal ( = thyroid)

Thyroboline (= thyroid)

Thyrodex tablets contain $30 \mathrm{mg}$ thyroid

Thyroglobuline thyroid protein containing not less than $0.3 \%$ I

Thyroid (B.P.) contains $0.25 \%$ I

Thyrophem tablets contain $30 \mathrm{mg}$ thyroid

Thyropit tablets contain $200 \mathrm{mg}$ thyroid

*Thyroxine contains $65 \%$ I

*Tri-iodothyronine (= liothyronine)

Vitamin-mineral and dietary preparations ${ }^{2}$

Avozan 4 capsulettes (daily dose) contain $0.1 \mathrm{mg} \mathrm{I}$

Azymil capsules contain $0 \cdot 1 \mathrm{mg}$ I

Complan contains $44 \mu \mathrm{g} I / 100 \mathrm{~g}$

Dekrasil capsules contain $150 \mu \mathrm{g}$

Gevrabon (Grayson, 1960)

Gevral capsules contain $10 \mu \mathrm{g}$ I (as KI)

*Iodized codliver oil contains $0.1 \%$ w/w I

Iodized vitamin capsules (Thomson) contain $150 \mu \mathrm{g} \mathrm{I}$

McClung Vi-Tabs contain 0.15 mg I (as KI)

*Metrecal (Steinberg and Leifheit, 1965)

Micebrin (Grayson, 1960)

Selora (salt substitute) contains $0.01 \% \mathrm{w} / \mathrm{w} \mathrm{KI}$

Supavite capsules contain $150 \mu \mathrm{g} \mathrm{I}$

Super Plenamins capsules contain $150 \mu \mathrm{g}$ I

${ }^{2}$ Complevite and Pregnavite contain traces of iodine and Sanatogen selected multivitamins contain iodine (exact quantities not specified).
Totavite capsules contain $0 \cdot 1 \mathrm{mg}$ I (as $\mathrm{KI}$ )

Unicap capsules (Grayson, 1960)

Vibolex tablets contain $0.05 \mathrm{mg} \mathrm{KI}$

Vykmin black capsules contain $0.2 \mathrm{mg} \mathrm{KI}$

Virol contains $265 \mu \mathrm{g} \mathrm{I} / 100 \mathrm{~g}$

\section{RADIOGRAPHIC CONTRAST MEDIA}

Apart from barium sulphate, all radiographic contrast media contain iodine. The effect of the majority of such compounds on the serum PBI has not been reported. However, all those which have been studied caused elevations of serum PBI, ranging from a few days to at least $\mathbf{3 0}$ years.

Individual contrast media are not listed here. Lists are given in Martindale's Extra Pharmacopoeia (25th ed, 1967), and in Iodine Pharmaceuticals (1952 and 3rd supplement 1956, published by the Chilean Iodine Educational Bureau). It may be assumed that all radiographic contrast media (other than barium sulphate) will cause false raised levels of the serum PBI which may often persist for several months or years. The effects of intravenous aqueous contrast media are usually shortlived (several days to a few weeks), gallbladder contrast media are often of intermediate life (one to three months) whereas those of oily media for bronchography or myelography and some gallbladder contrast media may persist for years (see Sisson 1965; Davis 1966).

\section{Miscellaneous}

Activin contains iodinated casein (concentration not stated) Algocor (= 2 ethyl-(3:5 diiodo-4 hydroxybenzoyl) 3-benzofuran) Antilusin (= pentamethonium iodide)

Arocalcin (Pitman-Moore Division of Dow Chemical Corp., Indianapolis, USA)

Arteriodon contains hexamethyldiaminoisopropanol di-iodide (quantity not stated)

Aurum Ambrosium contains $0.001 \% \mathrm{KI}$

* Benziodarone (Harrison and Cameron, 1965) contains $46 \%$ I

*Bi-Iochinol contains $8 \%$ quinine iodobismuthate

*Bismosalvan contains $10 \%$ quinine iodobismuthate

*Bromsulphthalein. Some batches contaminated with organic iodine (Pileggi, Segal, and Lanchantin, 1963)

*Cardivix (= benziodarone)

Chlorosane tablets contain iodine (quantity not stated)

*C-Van contains $1.5 \%$ available iodine

*Darbid (= isopropamide iodide)

*Decamethonium iodide contains $49.5 \%$ I

*Dimethyltubocurarine iodide contains $35 \%$ I

Ekner Seltzer contains $0.01 \% \mathrm{NaI}$

Endoiodine contains hexamethyldiaminoisopropanol di-iodide (quantity not stated)

Endojodin contains hexamethyldiaminoisopropanol di-iodide (quantity not stated)

*Entodon ( $=$ hexamethyldiaminoisopropanol di-iodide)

*Erythrosine (tetraiodofluorescein) red colorant for food and drugs

(Andersen et al, 1964).

Eskornade spansule contains $5 \mathrm{mg}$ isopropamide iodide

Eskornade syrup contains $15 \mathrm{mg}$ isopropamide iodide per $100 \mathrm{ml}$

*Estomycin (= penethamate hydriodide)

*Estopen (= penethamate hydriodide) 
*2-Ethyl (3:5 diiodo-4-hydroxybenzoyl) 3-benzofuran (Andreoli and de Luca, 1964)

*Eulissin (= decamethonium iodide)

*Flaxedil (= gallamine triethiodide)

G.S. tablets contain $8 \mathrm{mg} \mathrm{KI}$

*Gallamine triethiodide contains $42.5 \%$ I

Gibert's syrup contains $50 \mathrm{mg} \mathrm{HgI}_{2}$ per $100 \mathrm{~g}$ and $2.5 \%$ w/w KI

Hall's wine contains not less than $103 \mu \mathrm{g} I$ per $100 \mathrm{ml}$

Halmagon tablets contain $30 \mu \mathrm{g}$ of $\mathbf{M g I}_{2}$

*Hexamethyldiaminoisopropanol di-iodide contains $59.5 \%$ I

*5-Iodothiouracil (Starr, Petit, Chaney, Rollman, Aiken, Jamieson, and King, 1950; Bondy, 1951)

Isopropamide iodide contains $64 \%$ I

*Itrumil (= 5-iodothiouracil)

* Leocillin ( $=$ penethamate hydriodide)

Limodin (Central Pharmaceutical Co., Indianapolis, USA) contains KI (quantity not stated)

* Liquor Iodo-Creosotal contains $0.18 \% \mathrm{I}$ in combination with peptone * Lysanthine Astier (= Lyxanthine) contains $12 \%$ sodium iodopropanol sulphonate $(39 \%$ I)

* Metubine iodide (= dimethyltubocurarine iodide)

*Natex 'Four', 'Five', and 'Nine' contain $10 \%$ seaweeds * Natex 'Thirty-One' contains $15 \%$ seaweeds

*Natex 'Twenty-Two' and 'Thirty-Two' contain 20\% seaweeds

* Natex 'Eleven' contains $50 \%$ seaweeds

* Neobismosalvan contains $10 \%$ quinine iodobismuthate

* Neopenil (= penethamate hydriodide)

*Niblett's (Dr) nerve sedative contains $3.63 \% \mathrm{KI}$

* Penethamate hydriodide contains $22.5 \%$ I

* Pentamethonium iodide contains $57.5 \%$ I

* Perphenazine (some formulations may contain iodinated contaminants-Hansen and Siersbaek-Nielsen, 1967)

Potter's herbal blood compound contains $0.24 \% \mathrm{KI}$

Priamide ( $=$ isopropamide iodide)

*Pralidoxime (iodide form). See Kondritzer, Svirblis, Goodman, and Paplanus (1968)

Procol capsules contain $2.5 \mathrm{mg}$ isopropamide iodide

*Quinine iodobismuthate contains $57 \%$ iodine

*Seaweed (see bladderwrack)

Stelabid tablets contain $5 \mathrm{mg}$ isopropamide iodide

*Syncurine (= decamethonium iodide)

*Tetraiodofluorescein ( $=$ erythrosine)

Tyrimide ( $=$ isopropamide iodide)

\section{GOITROGENS}

Goitrogens are defined as substances which interfere with the synthesis of thyroid hormone by the thyroid gland and are capable of producing thyroid enlargement (see Wayne et al, 1964). They may act on the iodide trapping mechanism (perchlorate type), on organic iodine synthesis (thiouracil type), or peripherally on $T_{4}$ reabsorption (soya bean). The mechanisms of goitrogenic action of fluorides (Galletti and Joyet, 1958) and lithium carbonate (Sedvall, Jönsson, Petterson, and Levin, 1968) have not been elucidated. The effect of chlorpropamide treatment on the thyroid in diabetic patients is controversial. Hunton, Wells, and Skipper (1965) reported that clinically hypothyroid diabetic patients showed rises in serum PBI levels from hypothyroid levels on withdrawing chlorpropamide. On the other hand, Burke, Silverstein, and Sorkin (1967) did not observe any difference in serum PBI levels between groups of diabetics on chlorpropamide and on insulin. Burdick and Brice (1968) reported that serum PBI levels in sulphonylurea-treated diabetics were lower than in patients treated by insulin and diet, but that they were not usually in the hypothyroid range. These findings reflect the notorious difficulty in diagnosing borderline hypothyroidism and suggest that other factors, eg, varying individual susceptibility to chlorpropamide, dietary goitrogens, or iodide intake, may influence the response of the thyroid to chlorpropamide.

Goitrogens include antithyroid drugs which are used to treat thyrotoxicosis. Small doses of these drugs have no effect on the serum PBI since the rate of thyroid hormone secretion is maintained by a compensatory increase in TSH secretion. Doses large enough to cause hypothyroidism will lead to a reduction in the serum PBI level. Propylthiouracil reduces peripheral deiodination of $\mathrm{T}_{4}$, particularly in thyrotoxicosis (Hershman, 1964; Furth, Rives, and Becker, 1966), but this is not important diagnostically.

\begin{tabular}{|c|c|}
\hline Goitrogen & Reference \\
\hline \multicolumn{2}{|l|}{ Perchlorate Type } \\
\hline Bi-iodate & $\begin{array}{l}\text { Wyngaarden, Wright, and Ways } \\
\text { (1952) }\end{array}$ \\
\hline Chlorate & Wyngaarden et al (1952) \\
\hline *Difluorophosphate & $\begin{array}{l}\text { Anbar, Guttmann, and Lewitus } \\
\text { (1959) }\end{array}$ \\
\hline Fluoride (probably) & See above \\
\hline *Fluoroborate & Anbar et el (1959) \\
\hline Hypochlorite & Wyngaarden et al (1952) \\
\hline Iodate & Wyngaarden et al (1952) \\
\hline *Monofluorosulphonate & Anbar et al (1959) \\
\hline Nitrate & Wyngaarden et al (1952) \\
\hline * Perchlorate & Wyngaarden et al (1952) \\
\hline *Periodate & Wyngaarden et al (1952) \\
\hline \multicolumn{2}{|l|}{ Thiouracil Type } \\
\hline *Acetazolamide & $\begin{array}{l}\text { Gabrilove, Alvarez, and Soffer } \\
\text { (1958) }\end{array}$ \\
\hline ACTH & Notter (1962) \\
\hline *a-amino- $\beta$-hydroxy butyrate & $\begin{array}{l}\text { Greggia, Maggi,Mucci,Patrignani, } \\
\text { and Sternieri (1968) }\end{array}$ \\
\hline *Amino-glutethimide & $\begin{array}{l}\text { Rallison, Kumagai, and Tyler } \\
\text { (1967) }\end{array}$ \\
\hline *Aminotriazole & Alexander (1959) \\
\hline *Amphenone & $\begin{array}{l}\text { Selenkow, Rivera, and Thorn } \\
\text { (1957) }\end{array}$ \\
\hline BAL & Current, Hales, and Dobyns (1960) \\
\hline *Carbimazole & - \\
\hline Carbutamide & Brown and Solomon (1956) \\
\hline Chlorpropamide & See above \\
\hline Cobaltous chloride & $\begin{array}{l}\text { Robey, Veazey, and Crawford } \\
\text { (1956); Roche and Layrisse (1956) }\end{array}$ \\
\hline *Cortisone & $\begin{array}{l}\text { Hill, Reiss, Forsham, and Thorn } \\
\text { (1950); Berson and Yalow (1952) } \\
\text { (also lowers PBI concentration by } \\
\text { haemodilution - Blomstedt and } \\
\text { Einhorn, 1967) }\end{array}$ \\
\hline Cyanide & $\begin{array}{l}\text { Hardy, Jeffries, Wasserman, and } \\
\text { Waddell (1950) }\end{array}$ \\
\hline
\end{tabular}




2, 4-D
DOCA
"Hydrocortisone
"Lithium carbonate
"Methimazole
*Methylthiouracil
*Oxyphenbutazone
"PAB
*PAS

*PAS

*Parabromdylamine maleate Phenindione

Phenylbutazone

* Prednisolone

*Prednisone

Progesterone

* Propylthiouracil

* Resorcinol

Salicylate

Sulphonamides

Sulphonyl urea drugs

Thalidomide

Thiopentone

*Thiouracil

Tolbutamide

U-9189

Vitamin A

Florsheim and Velcoff (1962)

Zingg and Perry (1953)

Danowski et al (1962)

Sedvall et al (1968)

See Wilber and Odell (1965)

Wayne et al (1964)

Goodwin, Miller, and Wayne (1949)

MacGregor and Somner (1954);

Munkner (1965)

Sharpe (1961)

Williams and Doniach (1961);

Stewart and Grayson (1966)

Lüllmann (1962)

Sherer and Siefring (1956); Wik-

holm and Einhorn (1963)

Sherer and Siefring (1956)

Zingg and Perry (1953)

Bull and Fraser (1950); Doniach and Fraser (1950)

Good, Potter, and Hetzel (1965)

Milne and Greer (1962)

See chlorpropamide

Murdoch and Campbell (1958)

Wase, Repplinger, and Foster (1953)

Brown and Solomon (1956)

Ingbar (1961b)

Danowski, Wirth, Black, Barton, and Bastiani (1955); Logan (1957); Benedek (1962)

Other Antithyroid Substances

${ }^{131} I$ in high dosage

${ }^{125} \mathrm{I}$ in high dosage
Greig, Smith, Gillespie, Thomson, and McGirr (1969)

\section{DRUGS AFFECTING THYROXINE-BINDING}

\section{CAPACITY OF SERUM}

Drugs may affect the serum PBI as a result of interference with its thyroxine-binding properties. They may increase the serum PBI as a result of increasing the level of circulating TBG. Alternatively, they may reduce the serum $\mathrm{PBI}$ as a result of decreasing the level of circulating TBG or TBPA or as a result of competing with $\mathrm{T}_{4}$ for TBG. Changes in the level of circulating TBG or TBPA are presumed to arise from drug-induced alterations in their rates of synthesis by the liver. The effects of drugs are given in Tables I-V.

Drug Reference

*Androgens (including 'anabolic' steroids) $)^{1}$

$\mathrm{Eg}$, methyltestosterone. norethandrolone, oxymetholone, testosterone

See Keitel and Sherer (1957); Federman et al (1958); Engbring and Engstrom (1959); Braverman and Ingbar (1967); Rosin and Farran (1968)

Table I Drugs which may decrease the serum PBI level by lowering the concentration of circulating $T B G$

'Methylandrostenolone does not affect the PBI (Danowski et al 1965).

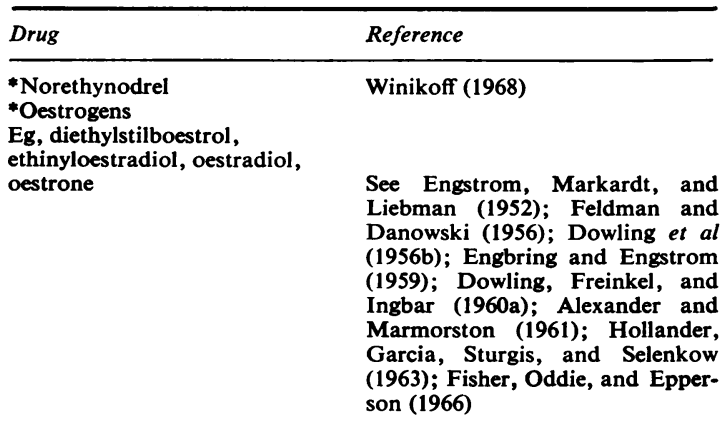

Oral contraceptives containing oestrogens The oestrogenic constituents are responsible. The progestogenic constituents, other than norethynodrel, have no effect on PBI (Winikoff, 1968)

*Perphenazine See Oltman and Friedman (1963); Cranswick and Simpson (1963 and 1964) but iodinated contaminants may be present in the formulation (Hansen and Siersbaek-Nielsen, 1967)

Table II Drugs increasing serum PBI level by raising concentration of circulating $T B G$

\begin{tabular}{|c|c|}
\hline Drug & Reference \\
\hline $\begin{array}{l}\text { Adrenaline } \\
\text { Animal experiments suggest that } \\
\text { adrenaline causes release of } \\
\text { PBI from the thyroid }\end{array}$ & $\begin{array}{l}\text { Korst and Beierwaltes (1956); } \\
\text { (Botkin and Jensen, 1952; Acker- } \\
\text { man and Arons, 1958) }\end{array}$ \\
\hline $\begin{array}{l}\text { Chlorpromazine } \\
\text { Evan's blue } \\
\\
\text { *Hydrochlorothiazide } \\
\text { Niagara sky blue } \\
\text { Niagara sky blue G.B. } \\
\text { Trypan blue }\end{array}$ & $\begin{array}{l}\text { Reichlin, Koussa, and Witt (1959) } \\
\text { Yamada, Whallon, Tomizawa, } \\
\text { Shimoda, and Schichijo (1965) } \\
\text { Mehbod et al (1967) } \\
\text { Yamada et al (1965) } \\
\text { Yamada et al (1965) } \\
\text { Yamada et al (1965) }\end{array}$ \\
\hline
\end{tabular}

Table III Drugs decreasing serum PBI by unknown means

Drug Reference

* Deseril ( = lysergic acid

butanolamide)

* Ether (anesthesia) causes

mobilization of PBI stores

Fluoropyrimidines

Insulin

Possibly stimulates TSH release Sendrail et al (1966)

Fore, Kohler, and Wynn (1966)

Lysergic acid butanolamide

In rats stimulates TSH release

and has variable action on

thyroid ${ }^{131}$ I uptake

Mess and Szántó (1964); Szántó and Reviczky (1966)

Variable effect on thyroid ${ }^{191}$ I uptake in rats

Szántó, Reviczky, and Grynaeus (1964)

De Simoni (1957)

Pyrazinamide

Vasopressin

Stimulates thyroid ${ }^{131}$ I release Garcia, Harris, and Schindler (1964)

Table IV Drugs increasing serum PBI by unknown means 


\begin{tabular}{|c|c|}
\hline Drug & Reference \\
\hline *BHDB & $\begin{array}{l}\text { Escobar del Rey and Morreale de } \\
\text { Escobar (1962) }\end{array}$ \\
\hline \multicolumn{2}{|c|}{$\begin{array}{l}\text { Butyl-4-hydroxy-3:5-di-iodobenzoate (= BHDB) } \\
\text { 2,2(4-chlorophenyl,2-chlorophenyl) 1,1-dichloroethane (= Op 'DDD) } \\
\text { DNP (= 2:4-dinitrophenol) } \\
\text { "Dilantin (= diphenylhydantoin) }\end{array}$} \\
\hline 2:4-Dinitrophenol & $\begin{array}{l}\text { Wolff, Standaert, and Rall (1961); } \\
\text { Morreale de Escobar and Escobar } \\
\text { del Rey (1961 a and b) }\end{array}$ \\
\hline $\begin{array}{l}\text { *Diphenylhydantoin (long-term } \\
\text { therapy) }\end{array}$ & $\begin{array}{l}\text { Wolff et al (1961); Lightfoot and } \\
\text { Christian (1966) Chin and Schussler } \\
\text { (1968). Acute treatment is without } \\
\text { effect (Levy and Marshall, 1964) }\end{array}$ \\
\hline Gentisate & Woeber and Ingbar (1964) \\
\hline Op'DDD & $\begin{array}{l}\text { Danowski, Sarver, Moses, and } \\
\text { Bonessi (1964); Marshall and } \\
\text { Tompkins (1968) }\end{array}$ \\
\hline$\gamma$-Resorcylate & $\begin{array}{l}\text { Woeber and Ingbar (1964); Good } \\
\text { et al (1965) }\end{array}$ \\
\hline Salic & $\begin{array}{l}\text { Austen et al (1958); Christensen } \\
\text { (1959); Wolff et al (1961); Good } \\
\text { et al (1965) }\end{array}$ \\
\hline
\end{tabular}

Table $\mathrm{V}$ Drugs decreasing serum $P B I$ by competing with $T$, for $T B G$ or $T B P A$

\section{Appendix II}

\section{Drugs Reported not to Cause Changes in the Serum PBI Level}

\begin{tabular}{ll}
\hline Drug & Reference \\
\hline Acetazolamide & Schteingart et al (1960) \\
Amphenidone & Pittman (1962) \\
Atromid (= clofibrate) & Vivacqua, Haurani, and Erslev \\
Busulphan & $(1967)$
\end{tabular}

Calcium

Chorionic gonadotropin

Chlormadinone

Chlorphenindione

Clofibrate

Clomiphene

Cyclopropane (anaesthesia)

Digitoxin

Dimethisterone

Ethisterone

G 25671 (phenylbutazone

analogue)

Halothane (anaesthesia)

Hydrochlorothiazide

Insidon (= opipranol)

Medroxyprogesterone

\section{Megestrol}

1-Methyl- $\Delta^{\mathbf{1}}$-androstenolone Metronidazole

Nicoumalone

Nitrous oxide (anaesthesia)

Norethisterone

Opipranol

Pontocaine

Propranolol

Schiller's solution

(cervical smears)

Surital

Tetracycline

Thiopentone (anaesthesia)

Thioridazine

Warfarin
Harrison, Harden, and Alexander (1967)

Craig et al (1963). Average increase of $0.6 \mu \mathrm{g} / 100 \mathrm{ml}$ not statistically significant

Winikoff (1968)

Stewart and Grayson (1966)

Harrison and Harden (1966) found no effect on serum PBI

Chang, Pinson, and Malone (1967)

found reduced TBPA capacity but normal TBG capacity

Cushman, Alter, and Hilton (1965)

Fore et al (1966)

Danowski et al (1965)

Winikoff (1968)

Winikoff (1968)

Linsk, Paton, Persky, Isaacs, and Kupperman (1957)

Fore et al (1966)

Schteingart et al (1960)

(In contraceptive preparations, Hollander et al, 1963; Winikoff, 1968.) A large dose given to suppress the pituitary in precocious puberty has caused hypothyroidism (Hubble, 1963)

Winikoff (1968)

Danowski et al (1965)

Harden, Chisholm, and Cant (1967)

Stewart and Grayson (1966)

Fore et al (1966)

Winikoff (1968)

Bourquin (1967)

Fore et al (1966)

Krikler (1966)

Braverman et al (1968)

Fore et al (1966)

Becker, Katz, and Miale (1967)

Fore et al (1966)

Taubert, Haskins, and Moszkowski (1966)

Stewart and Grayson (1966) 